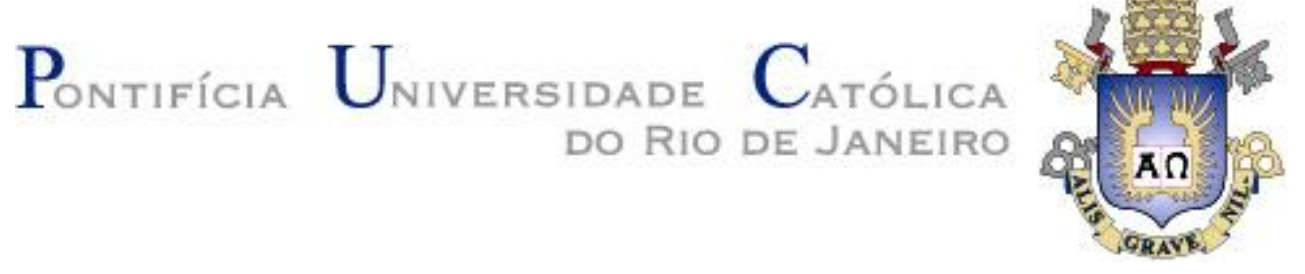

Lucas Martins Turano

\title{
Discurso, Emoções e Autenticidade na Liderança: Um Estudo Experimental
}

Dissertação de Mestrado

Dissertação apresentada ao Programa de Pósgraduação em Administração de Empresas da PUCRio como requisito parcial para obtenção do título de Mestre em Administração de Empresas.

Orientadora: Profa ${ }^{a}$. Flávia de Souza Costa Neves Cavazotte

Rio de Janeiro

Março de 2015 


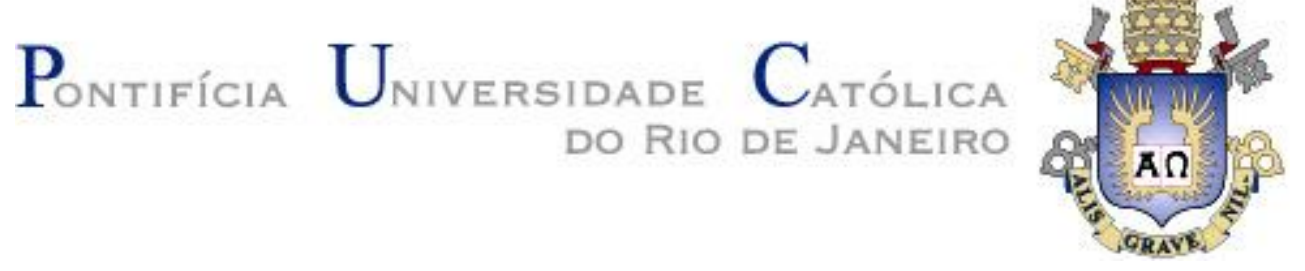

Lucas Martins Turano

\section{Discurso, Emoções e Autenticidade na Liderança: Um Estudo Experimental}

Dissertação apresentada ao Programa de Pósgraduação em Administração de Empresas da PUCRio como requisito parcial para obtenção do título de Mestre em Administração de Empresas. Aprovada pela Comissão Examinadora abaixo assinada.

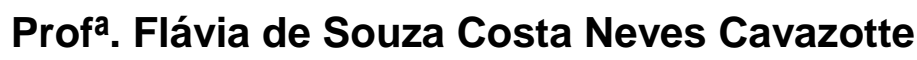
Orientadora

Departamento de Administração - IAG/PUC-Rio

Prof. Jorge Manoel Teixeira Carneiro Departamento de Administração - IAG/PUC-Rio

Prof. Eduardo Bittencourt Andrade Departamento de Administração - EBAPE/FGV

Prof? . Mônica Herz

Vice-Decana de Pós-Graduação do CCS - PUC-Rio

Rio de Janeiro, 27 de março de 2015 
Todos os direitos reservados. É proibida a reprodução total ou parcial do trabalho sem autorização da universidade, do autor e do orientador.

\section{Lucas Martins Turano}

Graduou-se em Administração de Empresas na Pontifícia Universidade Católica (IAG/PUC-Rio) em 2012. Pesquisador nas áreas de Liderança, Comportamento Organizacional, Estratégia, Sustentabilidade.

Ficha Catalográfica

Turano, Lucas Martins

Discurso, emoções e autenticidade na liderança : um estudo experimental / Lucas Martins Turano ; orientadora: Flávia de Souza Costa Neves Cavazotte. - 2015

102 f.: il. (color.) ; $30 \mathrm{~cm}$

Dissertação (mestrado)-Pontifícia Universidade Católica do Rio de Janeiro, Departamento de Administração, 2015.

Inclui bibliografia

1. Administração - Teses. 2. Discurso. 3. Emoções. 4. Autenticidade. 5. Liderança. 6. Seguidores. I. Cavazotte, Flávia de Souza Costa Neves. II. Pontifícia Universidade Católica do Rio de Janeiro. Departamento de Administração. III. Título. 


\section{Agradecimentos}

Dedico este trabalho a Deus. Agradeço, sobretudo, por suas infinitas possibilidades de amadurecimento e crescimento pessoal, sempre com um infinito amor e bondade.

Agradeço à professora Flávia Cavazotte pela sua orientação e dedicação em passar seus conhecimentos para a elaboração dessa pesquisa.

Agradeço aos professores que tive ao longo da vida que me ensinaram e educaram, e que sem os quais não teria chegado até aqui.

Agradeço à PUC-Rio por ter me possibilitado um universo de oportunidades e atividades para meu desenvolvimento pessoal e profissional.

Agradeço à CAPES, pelos auxílios concedidos, sem os quais este trabalho não poderia ter sido realizado.

Agradeço à minha mãe, que, acima de tudo, pensa no bem e no meu amadurecimento, fornecendo carinho e amor.

Agradeço ao meu pai, que sempre me frisou à importância dos estudos e me deu grande apoio para que eu me aperfeiçoasse ao máximo.

Agradeço ao meu irmão, que me deu um sentido à vida, me guiou, me auxiliou e me ensinou tudo que realmente importa.

Agradeço a minha companheira e futura esposa, por todo o apoio nessa caminhada e por compartilhar todos os sonhos comigo.

Agradeço à minha família como um todo, que sempre esteve presente em minha vida, me dando suporte e uma base sólida de educação.

Agradeço aos meus amigos, que ao longo da vida compartilharam momentos felizes e tristes ao meu lado. 


\section{Resumo}

Turano, Lucas Martins; Cavazotte, Flávia de Souza Costa Neves. Discurso, Emoções e Autenticidade na Liderança: Um estudo experimental. Rio de Janeiro, 2015. 102p. Dissertação de Mestrado - Departamento de Administração, Pontifícia Universidade Católica do Rio de Janeiro.

A moralidade e o equilíbrio de um líder, bem como sua positividade, são pressupostos teóricos centrais na teoria da liderança autêntica. Tomando esses pressupostos como objeto de estudo, a presente pesquisa investiga empiricamente o impacto de princípios autênticos no discurso de um líder e da sua expressão de emoções na percepção de eficácia na liderança, por meio de dois experimentos. O primeiro estudo investigou o efeito do discurso autêntico nos julgamentos de seguidores de diferentes áreas ocupacionais sobre a liderança. Os resultados indicam que o endosso a princípios da liderança autêntica no discurso de um líder influencia positivamente a percepção de eficácia na liderança. Porém, esse efeito é significativamente menor entre profissionais das áreas de Finanças e de Marketing/Vendas. O segundo experimento investigou a influência da expressão de emoções positivas e negativas nos julgamentos sobre a eficácia de um líder que endossa valores autênticos. Os resultados evidenciaram que a expressão de afetividade negativa (tristeza/desânimo) influenciou negativamente a percepção de eficácia na liderança. Porém, a expressão de afetividade positiva (alegria/ânimo) não influenciou positivamente esta percepção. Esses achados são discutidos quanto às suas implicações teóricas, e, sobretudo, práticas.

\section{Palavras-chave}

Discurso; Emoções; Autenticidade; Liderança; Seguidores 


\section{Abstract}

Turano, Lucas Martins; Cavazotte, Flávia de Souza Costa Neves (Advisor). Discourse, Emotions and Authenticity in Leadership: An Experimental Study. Rio de Janeiro, 2015. 102p. MSc. Dissertation - Departamento de Administração, Pontifícia Universidade Católica do Rio de Janeiro.

Morality, balance of a leader and his positivity, are central theoretical assumptions in the theory of authentic leadership. Taking these assumptions as object of study, this research empirically investigates the impact of authentic principles in the speech of a leader and the expression of emotions in the perception of leadership effectiveness through two experiments. The first study investigated the effect of authentic speech in the judgements of followers from different occupational areas on the leadership. The results indicate that the endorsement of principles of authentic leadership in the speech of a leader influences positively the perception of leadership effectiveness. However, this effect is significantly lower among professionals in Finance and Marketing/Sales areas. The second experiment investigated the influence of the expression of positive and negative emotions in the trials on the effectiveness of a leader who endorse authentic values. The results showed that the negative affectivity expression (sadness/depression) influenced negatively the perception of leadership effectiveness. However, the positive affect expression (happiness/enthusiasm) not influence positively this perception. These findings are discussed to show their theoretical, and, above all, practical implications.

\section{Keywords}

Discourse; Emotions; Authenticity; Leadership; Followers 


\section{Sumário}

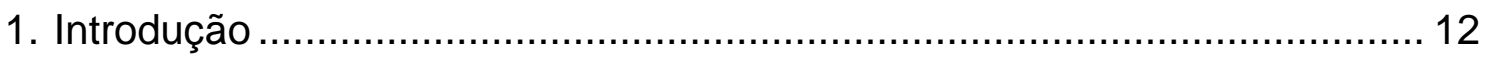

1.1 Contextualização do Problema ....................................................... 12

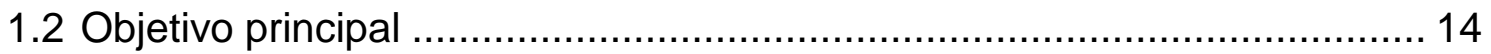

1.3 Relevância do Estudo .................................................................... 14

1.4 Delimitação do Estudo ............................................................ 15

1.5 Estrutura da Pesquisa.............................................................. 16

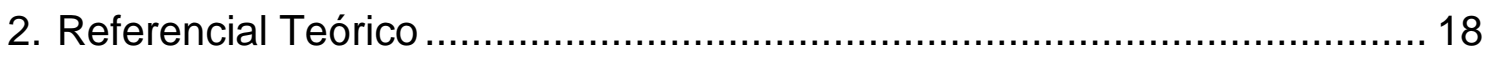

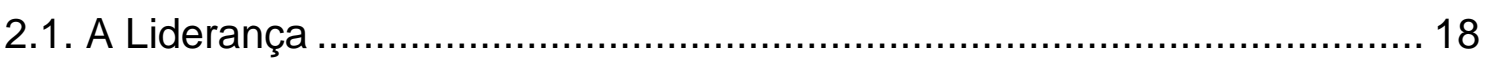

2.1.1. Histórico das Teorias ............................................................. 19

2.2. Liderança Autêntica.................................................................. 23

2.2.1. Histórico da Liderança Autêntica .......................................................... 23

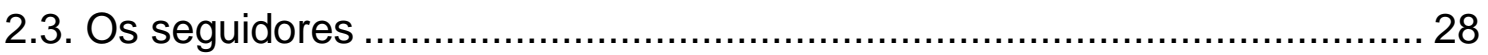

2.3.1. Histórico e Importância dos Seguidores .......................................... 28

2.3.3. Seguidores x Efetividade do Líder Autêntico...................................... 30

2.3.4. Seguidores x Identidade com o Líder Autêntico ................................... 31

2.4. A Influência da Área Ocupacional na Valoração do Líder ......................... 31

2.4.1 A área de Marketing ........................................................................ 33

2.5. A Influência das emoções na Valoração do Líder ................................... 37

2.5.1 Emoções e sua Importância para a Liderança .................................. 37

2.5.2. A Positividade e Negatividade das Emoções na Liderança................... 40

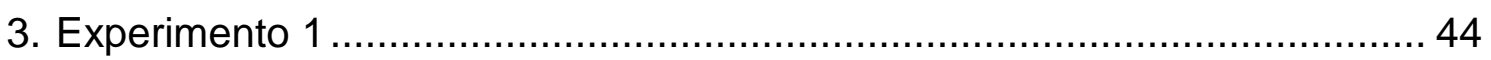

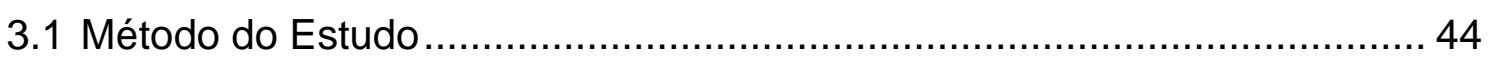

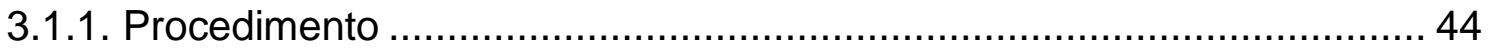

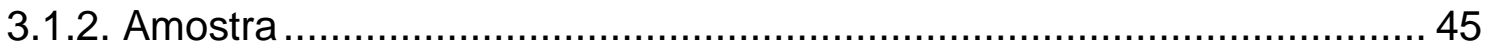

3.1.3. Coleta de Dados................................................................. 46

3.1.4. Escalas de Mensuração ....................................................... 46

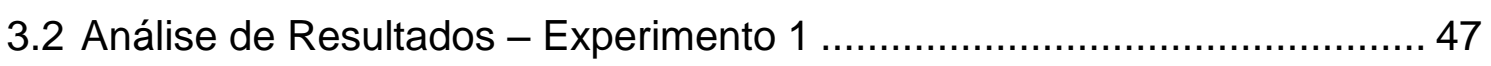

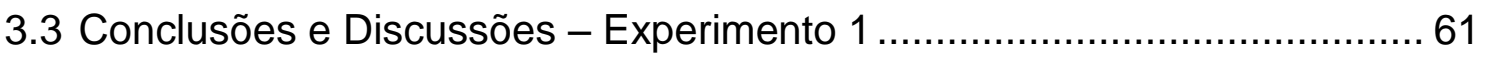


4. Experimento 2

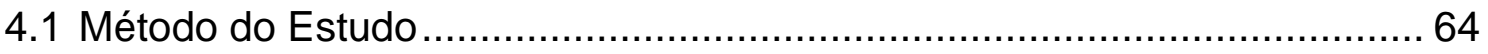

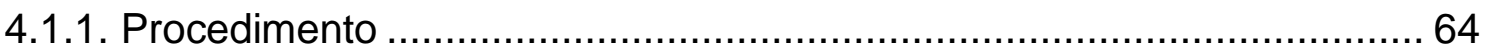

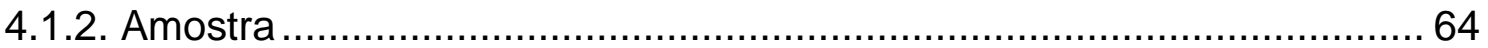

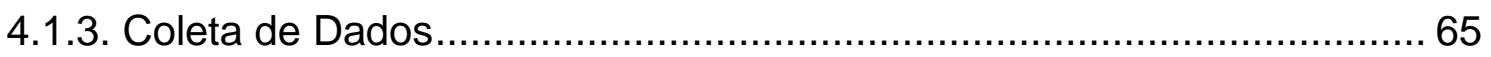

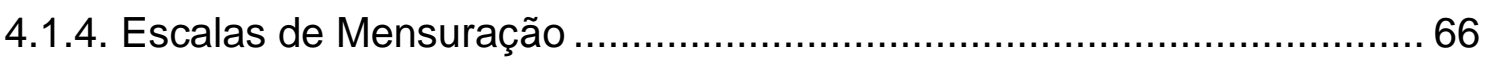

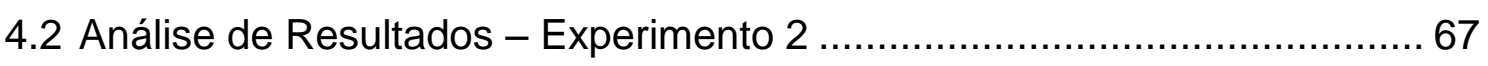

4.3 Conclusões e Discussões - Experimento 2 ……………………......... 72

5. Discussões Gerais e Considerações Finais ……………......................... 76

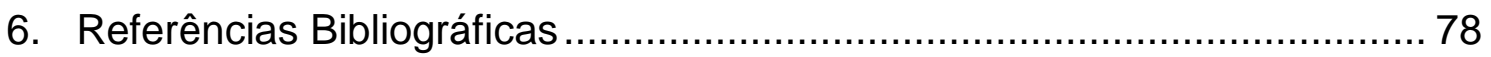

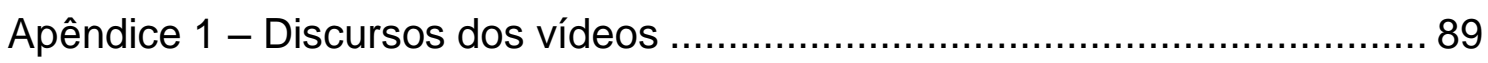

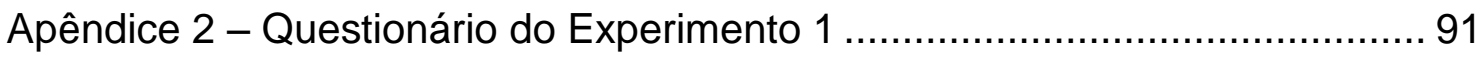

Apêndice 3 - Manipulação das emoções do líder ........................................... 96

Apêndice 4 - Questionário do Experimento 2 ….......................................... 97 


\section{Lista de Figuras}

Figura 1 - Modelo Proposto do Experimento 1 ............................................. 36

Figura 2 - Modelo Proposto do Experimento 2 …......................................... 43

Figura 3 - Grau de Identificação por Áreas Ocupacionais ................................ 53

Figura 4 - Percepção de Eficácia por Áreas Ocupacionais .............................. 53

Figura 5 - Grau de Identificação \& Percepção de Eficácia (Líder Autêntico).... 56

Figura 6 - Grau de Identificação \& Percepção de Eficácia (Inautêntico) ........... 60

Figura 7 - Grau de Identificação \& Percepção de Eficácia ............................... 72 


\section{Lista de Tabelas}

Tabela 1 - Dados Amostrais dos Participantes por Área e Vídeo Assistido ..... 45

Tabela 2 - ANOVA e Post Hoc para teste de Manipulação ………................... 48

Tabela 3 - Estatísticas Descritivas e Correlações para Amostra Total ............. 49

Tabela 4 - ANOVA e Post Hoc para efeito do Discurso na Identificação .......... 51

Tabela 5 - ANOVA e Post Hoc para efeito do discurso na Eficácia................... 51

Tabela 6 - Médias de Eficácia e Identificação por Grupos ............................... 52

Tabela 7 - Estatísticas Descritivas e Correlações para o Líder Autêntico ........ 54

Tabela 8 - ANOVA e Post Hoc para Identificação por Área - Autêntico ............ 55

Tabela 9 - ANOVA e Post Hoc para Eficácia por Área - Autêntico .................... 56

Tabela 10 - Estatísticas Descritivas e Correlações para o Líder Inautêntico ... 58

Tabela 11 - ANOVA e Post Hoc para Identificação por Área - Inautêntico....... 59

Tabela 12 - ANOVA e Post Hoc para Eficácia por Área - Inautêntico ............... 60

Tabela 13 - Dados Amostrais dos Participantes por vídeo assistido ................. 65

Tabela 14 - ANOVA e Post Hoc para teste do efeito da manipulação .............. 68

Tabela 15 - Estatísticas Descritivas e Coeficientes de Correlação ................... 69

Tabela 16 - ANOVA e Post Hoc para hipóteses de Eficácia ………………..... 70

Tabela 17 - Regressão para Percepção de Eficácia do Líder ........................... 70

Tabela 18 - ANOVA e Post Hoc para Hipóteses de Identificação ..................... 71 
“A liderança é uma poderosa combinação de estratégia e caráter. Mas se tiver de passar sem um, que seja a estratégia."

(Norman Schwarzkopf)

"Um líder deve fazer as pessoas ao redor se sentirem melhores, proporcionando um impacto positivo em suas vidas. Outra coisa é a preocupação com a sociedade, que deve se sobrepor ao seu ego e interesses pessoais." 


\section{1 \\ Introdução}

1.1.

Contextualização do Problema

A liderança é um dos fenômenos mais estudados dentro da área das ciências sociais atualmente (DAY; ANTONAKIS, 2012). Ela está presente em inúmeros ambientes: escolas, quartéis militares, empresas com fins lucrativos e quaisquer outros lugares onde ocorrem movimentos sociais. Por isso, esse processo se caracteriza como uma "valiosa disciplina para estudos e pesquisas científicas" (BASS, 2008, p. 25), visando, sobretudo, o aperfeiçoamento da eficácia e eficiência grupal.

O estudo da liderança possibilita um entendimento melhor das realizações coletivas e das dinâmicas sociais. Especificamente na área da Gestão e da Administração de Negócios, o fenômeno da liderança é de interesse central, sendo um veículo essencial na criação de valor em organizações (SCHEIN, 2007) e no planejamento e implementação de estratégias (KOTTER, 2001), tendo, por isso, recebido um grande destaque tanto na literatura acadêmica (YUKL, 1989, 2012) quanto na mídia de negócios (e.g. SCHREYER, 2010).

Além disso, no contexto atual de crises econômicas, escândalos corporativos e muitos exemplos de má liderança, a demanda por líderes mais éticos e conscientes tem se tornado crescente (NORTHOUSE, 2010). Nesse sentido, a teoria da liderança autêntica surgiu neste século para buscar suprir tais necessidades, não olvidando, ainda, da busca por melhores relacionamentos entre líderes e seguidores e pela ampliação da sua efetividade. Todavia, é importante ressaltar que o fenômeno da liderança não depende só do líder. Assim, apesar de muitas vezes negligenciados, compreende-se que os seguidores são de extrema relevância nesse processo (KELLEY, 1988), principalmente no que se refere às suas percepções e atribuições sobre o próprio líder (BROWN, 2012; BASS, 2008; MEINDL et al., 1985).

A teoria da liderança autêntica está pautada em pressupostos que afirmam que a moralidade, equilíbrio e positividade do líder são centrais para o processo 
(LUTHANS; AVOLIO, 2003). Contudo, ainda é necessário investigar empiricamente as suas premissas a fim de validá-las, uma vez que muitos elementos da própria teoria não estão plenamente desenvolvidos (NORTHOUSE, 2010).

Assim, partindo deste contexto, e visando verificar empiricamente estes pressupostos, o presente estudo levanta algumas questões. Será que líderes autênticos são considerados melhores líderes em todos os contextos? Será que o discurso autêntico (mais ético, equilibrado, transparente e consciente) tem apelo para todos os tipos de profissionais, ou será que profissionais de diferentes áreas ocupacionais (marketing, finanças etc.) percebem e avaliam de forma diferente esse tipo de líder? Como cada área funcional apresenta um conjunto bem específico de responsabilidades, atividades e rotinas, talvez as atribuições de eficácia a respeito desse tipo de líder sejam diversas. Por exemplo, como as áreas de marketing e de finanças, na maioria das vezes, têm maior envolvimento monetário e tendem a apresentar maiores dilemas éticos e morais (O’HIGGINS; KELLEHER, 2005), pode ser que um líder mais ético e autêntico seja percebido como menos eficaz.

Outra questão que este estudo levanta é se a expressão, por parte desse líder, de emoções positivas e negativas influencia as percepções e os julgamentos dos seguidores sobre o líder. Como a literatura ainda não apresenta muitas evidências dessa relação, apesar da relevância da positividade na construção da teoria (AVOLIO et al., 2004), faz-se necessário investigar se a manifestação dessas emoções influencia os julgamentos dos seguidores quanto à eficácia do líder pelos seguidores.

A partir destes questionamentos, em suma, o presente estudo busca analisar experimentalmente se discursos mais ou menos autênticos e se a expressão de emoções positivas e negativas influenciam as percepções de seguidores sobre líderes. Primeiramente, o estudo analisa se o discurso ético está associado com a efetividade de um líder, avaliada em termos de sua capacidade de provocar uma maior identificação entre os seguidores e atribuições de eficácia na liderança. Nesse sentido, o trabalho também busca observar os potenciais efeitos moderadores da área ocupacional (marketing, finanças e outras áreas) na percepção de seguidores sobre a efetividade de um líder autêntico. Posteriormente, a pesquisa investiga o impacto da expressão de afetividade na 
valoração de um líder autêntico pelos seguidores, avaliada em termos do grau de identificação do seguidor para com o líder e na percepção de eficácia do mesmo.

\section{2.}

\section{Objetivo principal}

O objetivo principal deste estudo é testar empiricamente, por meio de dois experimentos, os pressupostos teóricos preconizados pela teoria da liderança autêntica. Assim, busca-se analisar a influência de princípios autênticos no discurso e a expressão de emoções na percepção de efetividade (identificação e eficácia) do líder, atribuída por diferentes tipos de seguidores.

Com base nisso, o primeiro experimento analisa, por meio da manipulação experimental, se princípios de autenticidade no discurso de um líder influenciam os julgamentos de seguidores de diferentes áreas ocupacionais sobre a eficácia do líder, bem como seu grau de identificação com o mesmo.

O segundo experimento analisa, por meio da manipulação experimental, se as emoções de um líder autêntico (positivas/negativas), influenciam os julgamentos de seguidores de diferentes áreas ocupacionais sobre a eficácia do líder, bem como seu grau de identificação com o mesmo, conforme sugerem os princípios norteadores da teoria (AVOLIO et al., 2004).

\section{3.}

\section{Relevância do Estudo}

A relevância do presente estudo é evidenciada sob diversos aspectos. Em primeiro lugar, é relevante por se tratar de um experimento, método de pesquisa pouco utilizado nesse campo da liderança (DAY; ANTONAKIS, 2012). Ou seja, conforme Gardner et al. (2011) apontam, a utilização de métodos diferentes e igualmente rigorosos podem ser importantes pontos para a construção de pesquisas com resultados mais robustos. Além disso, pode-se dizer que o trabalho atende à necessidade exposta por Northouse (2010) de se realizar mais estudos empíricos sobre liderança autêntica, uma vez que esta teoria ainda não está plenamente desenvolvida e, portanto, precisa-se expandir a aplicação e entendimento do construto.

Outro ponto em que esse estudo se mostra relevante é o fato de que ele atende a lacuna percebida por Avolio e Reichard (2008) e Gardner et al. (2011), 
buscando entender melhor as potenciais influências dos seguidores no fenômeno da liderança, sobretudo no referente à investigação de suas características e percepções. Assim, o estudo contribui ao analisar empiricamente o papel dos seguidores nos relacionamentos autênticos (AVOLIO; REICHARD, 2008) e ao examinar expectativas, atitudes e percepções dos seguidores com base no comportamento do líder e na natureza da liderança (SHAMIR, 2007).

A relevância da pesquisa também se apresenta no experimento 1 ao tratar das diferenças entre áreas ocupacionais sob a ótica da avaliação da liderança. Até então, eram vistos estudos onde somente características relativas a função (e.g. FERREL et al., 2000) ou ao desenvolvimento moral de seus profissionais eram abordadas (e.g. O’HIGGINS; KELLEHER, 2005). Ou seja, não foram encontrados estudos onde os profissionais das diferentes áreas funcionais da empresa se relacionavam com a avaliação da eficácia de um líder, e mais ainda com um líder autêntico, seja por meio da percepção de identificação quanto sob a ótica da eficácia.

Por fim, no referente ao experimento 2, o estudo apresenta relevância teórica e prática, uma vez que, apesar de muitos estudos realizarem associações entre as emoções e a liderança, poucos são aqueles que as estudaram focados em um líder autêntico. Nesse sentido, foram encontrados muitos estudos onde emoções e liderança transformacional e transacional eram relacionadas (e.g. CONNELY; RUARK, 2010; ASHKANASY; TSE, 2000). Contudo, apesar da teoria autêntica discutir, em suas definições e proposições, as ideias de capacidades psicológicas positivas e de positividade das emoções (AVOLIO et al., 2004) e focar mais em processos afetivos e emocionais do que cognitivos (LORD; BROWN, 2004), poucos são os estudos onde esses princípios são, de fato, investigados. Assim, torna-se fundamental estudar profundamente estes efeitos.

\section{4. \\ Delimitação do Estudo}

Quanto à delimitação de escopo, esta pesquisa limita-se, primeiramente, a um único tipo ou teoria sobre lideres: autênticos. Sendo assim, não é objetivo observar o grau de identificação do seguidor com o líder e a percepção de eficácia de outros tipos de líderes além daqueles que possuem características de autenticidade. Nesse sentido, ressalta-se, que não é objetivo captar as percepções 
sobre as práticas de líderes autênticos, mas sim sob o que é expressado por meio de seus discursos e manifestações emocionais. Inclusive, também não é objetivo deste estudo investigar a eficácia do líder propriamente dita, mas sim as percepções dela atribuídas pelos seguidores. Ou seja, o escopo aqui é observar as atribuições sobre a efetividade e a atratividade exercida pelos elementos autênticos investigados (discurso moral e afetividade positiva) e não o comportamento ou desempenho verdadeiramente alcançado pelo líder.

Quanto à delimitação amostral para o primeiro experimento, cabe observar que a pesquisa está limitada a valoração de líderes por profissionais que estão cursando ou cursaram há pouco tempo (até 2 anos) uma pós graduação. Nesse sentido, a pesquisa limitou-se a realizar o experimento 1 com alunos de duas universidades, ambas localizadas na cidade do Rio de Janeiro.

Quanto ao segundo experimento, o estudo limitou-se a analisar as percepções de alunos de graduação de uma universidade privada localizada no Rio de Janeiro. Porém, optou-se por realizar o estudo somente com estudantes da faculdade de administração. Assim, não está no escopo desse estudo analisar percepções de estudantes de outros cursos, mesmo que pertencentes à mesma universidade na qual o experimento foi conduzido.

\section{5.}

\section{Estrutura da Pesquisa}

Como forma de facilitar a compreensão deste estudo, o presente trabalho se divide em outros quatro capítulos, além deste. Esta seção introdutória (1) apresenta os temas e construtos abordados, assim como discute a relevância, a delimitação e, essencialmente, os principais objetivos da pesquisa. Por sua vez, o capítulo subsequente (2) articula teorias para propor hipóteses de pesquisas e modelos a serem testados. Para construir esse diálogo entre teorias e trabalhos e atender apropriadamente ao objetivo proposto, foi feita uma extensa revisão da literatura sobre o tema que culminou na construção de cinco subseções: A Liderança (2.1), A Liderança Autêntica (2.2), Os Seguidores (2.3), A Influência da Cultura Ocupacional na Valoração do Líder (2.4) e, por fim, A Influência da Emocionalidade na Valoração do Líder (2.5).

Em seguida, os dois estudos foram separados e detalhadamente descritos, conforme a praxe em estudos de caráter experimental com mais de um 
experimento (e.g. DECELLES et al., 2012; SINACEUR et al., 2011; CIANCI et al., 2014). Assim, o capítulo 3, e mais especificamente as subseções 3.1, 3.2 e 3.3 são referentes, respectivamente, às seções de método, análise de resultados e conclusões do primeiro experimento, enquanto que no capítulo 4 , as subseções 4.1, 4.2 e 4.3 são referentes, respectivamente, às seções de método, análise de resultados e conclusões do segundo experimento. 


\section{2 \\ Referencial Teórico}

\section{1.}

\section{A Liderança}

O fenômeno da liderança é tido como um complexo e abrangente tema, o qual já acumula mais de um século de pesquisas (DAY; ANTONAKIS, 2012). Para Burns (1978), muitas informações científicas são geradas a partir dos trabalhos, mas até o final da década de 70 nenhuma conceituação plenamente aceita sobre liderança tinha emergido. Até a época, mais de 130 diferentes definições já haviam sido apresentadas na literatura (BURNS, 1978). Contudo, cada uma explora o processo por uma ótica distinta, enfatizando um ou outro aspecto presente no fenômeno (HUGHES et al., 2005; YUKL, 2006).

Para Bennis (1959), por exemplo, liderança está ligada ao poder formal de um agente sobre seus subordinados, negligenciando, assim, o aspecto informal presente no processo. Já Fiedler (1967) associa o fenômeno a um processo mais relacionado com o de gestão ao afirmar que a liderança poderia ser entendida como a coordenação e o direcionamento dos membros de um grupo para a realização do trabalho. Além disso, até meados da década de 80, a figura do líder era o ponto nevrálgico na grande maioria das definições do termo (BRYMAN, 2004), evidenciando, dessa maneira, a pouca importância que era dada para outros elementos, como o contexto, os seguidores e o relacionamento entre líderes e liderados (HUGHES et al., 2005).

Com base nesse entendimento, observa-se que, atualmente, uma conceituação mais consensual de liderança deve englobar determinados elementos, como: (a) processo de influência (b) interação entre líderes e seguidores, (c) envolvimento em um determinado contexto e (d) busca pelo atingimento de objetivos ou metas. Seguindo essa vertente e partindo da ótica proposta por Bergamini (2009), nesse estudo, a liderança é entendida como um processo social de interação entre líderes e seguidores, onde o líder busca influenciar e os seguidores buscam se engajar voluntariamente, por meio de uma associação, para buscar um determinado objetivo comum a todos, dentro de um determinado contexto. 
No Brasil, o interesse pelo tema tem se mostrado crescente nos últimos anos, revelando como a discussão vem sendo desenvolvida e organizada. Segundo Delfino et al. (2010), que analisaram a produção de pesquisas sobre o tema no país de 1995 a 2009, houve um aumento significativo nas publicações com o passar dos anos. O estudo ainda revela que 55\% dos trabalhos publicados nos anais do ENANPAD para o intervalo temporal adotado estão compreendidos entre os anos de 2006 e 2009. Por outro lado, evidenciou-se, também, que muitos dos estudos que foram apresentados em eventos não evoluíram para uma publicação em periódico (DELFINO et al., 2010). Em outro estudo bibliométrico sobre o tema no país, Santos et al. (2013) analisaram somente artigos publicados no ENANPAD de 2007 a 2012. Seus resultados mostraram a destacada presença de trabalhos utilizando uma metodologia foucaultiana, assim como uma maior busca pelo entendimento dos impactos da inteligência emocional no processo da liderança.

\subsection{1. \\ Histórico das Teorias}

Desde o início das pesquisas científicas sobre liderança, no século XX, o tema tem sido abordado sobre diferentes perspectivas, originando inúmeras teorias (VAN SETERS; FIELD, 1990). Na fase inicial, que se estendeu até o final da década de 40, a primeira tentativa de estudos sistemáticos sobre o fenômeno veio com a escola dos traços, também denominada "teoria do grande homem" (NORTHOUSE, 2010). De acordo com este autor, a teoria assenta em identificar os traços e as qualidades inatas que fazem com que determinadas pessoas se tornem grandes líderes. Portanto, acreditava-se que líderes já nasciam líderes (DAY; ANTONAKIS, 2012). Posteriormente, surgiram algumas críticas à teoria, afirmando que ela não considera fatores situacionais e não trata o processo de uma maneira holística, podendo, ainda, ser vista como bastante determinística (NORTHOUSE, 2010). Segundo Gardner et al. (2010), houve uma forte diminuição na proporção de artigos publicados no The Leadership Quarterly em que essa perspectiva era estudada.

Após essa fase, nos anos 50, deu-se início a estudos com abordagens comportamentais. Muitos pesquisadores que se desmotivaram com os resultados dos estudos que avaliavam os traços do líder começaram a se atentar para a forma 
com que os líderes agem no ambiente de trabalho (YUKL, 2006). Apesar de os estudos ainda terem foco na figura do líder, o comportamento grupal passou a ser analisado (BRYMAN, 2004). Nesse, sentido, foi descoberto que um líder pode ter estilos diferentes em seu relacionamento com liderados, variando em sua orientação. Primeiramente, um líder orientado para pessoas busca, fundamentalmente, criar um forte relacionamento com seus subordinados. Por outro lado, o ponto nevrálgico para um líder orientado para tarefas é a alta produtividade e o cumprimento de metas laborais (PARRY; BRYMAN, 2006).

Nos anos seguintes, a fase que se estendeu até o final da década de 60 se caracterizou por desenvolver as teorias contingenciais. Segundo Yukl (2006), essa abordagem explora, no processo de liderança, certos aspectos situacionais que podem alterar a efetividade e a influência de líderes. Alguns desses aspectos identificados são: estrutura de tarefa, poder hierárquico do líder e relacionamento entre líderes e membros (FIEDLER, 1967). Ou seja, de acordo com essa teoria, o desempenho do líder depende muito mais do contexto do que de sua personalidade ou comportamento e, portanto, o líder, para conseguir, efetivamente, exercer influência sobre o grupo, deve adaptar seu estilo de liderança conforme as diferentes situações (BOWDITCH; BUONO, 2002).

Para Yukl (2006), uma forte crítica às pesquisas acerca dessa perspectiva é o fato delas não utilizarem robustos métodos de coleta e análise de dados, uma vez que apresentam parâmetros que não foram adequadamente testados. Ademais, o autor ainda aponta que pesquisadores devem analisar o tema de uma forma mais holística, evitando uma investigação separada por meio dos tipos de comportamentos (YUKL, 2006). Com base em seus achados, Gardner et al. (2010) afirmam que essa perspectiva tem sido pouco estudada, contemplando apenas $1 \%$ dos trabalhos publicados, na primeira década do século XXI, no The Leadership Quarterly.

Um período após o movimento das teorias contingenciais surge a escola relacional da liderança, que foi se desenvolvendo até elaborar a teoria do LeaderMember Exchange (LMX) (DAY; ANTONAKIS, 2012). A maioria das teorias desenvolvidas até então haviam estudado o fenômeno sobre a perspectiva do líder e do contexto. Contudo, com a teoria LMX, a abordagem dada as pesquisas se alterou e o foco passou a ser a interação entre líderes e seguidores (NORTHOUSE, 2010). De acordo com Graen e Uhl-bien (1995), essa abordagem 
sugere que as interações de líderes com seguidores devem ser vistas como uma série de relacionamentos diádicos verticais. Dessa forma, observaram, ainda, que seguidores poderiam possuir dois diferentes tipos de relacionamento com o líder: um baseado, somente, no contrato formal de trabalho, onde o indivíduo possui os papéis plenamente definidos e outro pautado na confiança, no respeito e no alto envolvimento, onde o indivíduo detém papéis expandidos. Estes dois tipos de relacionamentos foram denominados out-group e in-group, respectivamente (GRAEN; UHL-BIEN, 1995).

A teoria LMX age tanto descrevendo a liderança como prescrevendo esse processo. No concernente a descrição, a abordagem demonstra que dentro de quaisquer grupos ou organizações, o reconhecimento dos out-groups e dos ingroups são de suma importância (NORTHOUSE, 2010). Prescritivamente, a LMX expõe que relacionamentos de alta qualidade geram melhores resultados do que aqueles em que o relacionamento entre líderes e seguidores não são pautados pelo respeito mútuo e pela confiança, achados esses que foram suportados em pesquisas empíricas (GERSTNER; DAY, 1997). Uma das maiores críticas a essa teoria é que ela poderia provocar injustiça no ambiente de trabalho, uma vez que líderes, na maioria dos casos, não possuem um tratamento igualitário para com todos os seus subordinados. Ademais, há, também, uma crítica referente ao fato de que algumas ideias básicas da teoria não foram totalmente desenvolvidas, como, por exemplo, a explicação de como se constrói uma interação de alta qualidade (NORTHOUSE, 2010).

Após a escola relacional, surgiu a teoria da liderança carismática, causando um novo grande impacto no campo científico. Essa teoria já é considerada um dos componentes presentes na "nova liderança" (DAY; ANTONAKIS, 2012). Sua literatura é baseada, primeiramente, no estudo de House (1977) e, posteriormente, nos trabalhos de Conger e Kanungo (1987) e Shamir et al. (1993). De acordo com estes autores, carisma é um elemento que é atribuído. Além disso, as habilidades carismáticas do seguidor e do líder são conjuntamente determinadas pela variação dos comportamentos do líder, experiências passadas e elementos situacionais (YUKL, 2006). Líderes carismáticos possuem, geralmente, um vínculo emocional único com seus seguidores, baseado, essencialmente, em valores. Dessa forma, seus impactos oriundos de suas habilidades carismáticas auxiliam no engajamento dos seguidores (HOUSE, 1977; SHAMIR et al, 1993). Além disso, a grande 
maioria deles possui uma forte autoconfiança e convicção em seus próprios ideais e crenças, assim como uma alta necessidade de poder (YUKL, 2006).

Por sua vez, as teorias da liderança transformacional e transacional, também presentes na "nova liderança", são baseadas, primordialmente, no trabalho de Burns (1978). De acordo com este autor, a liderança transformadora tem um efeito maior nos seguidores e nas massas, sendo baseada no transcender e no cumprimento de grandes metas e ideais. Já a liderança transacional tem um escopo mais limitado, sendo focada na promoção de interesses individuais. Ou seja, enquanto esta última é pautada em transações e na troca de elementos valiosos entre as partes, a primeira busca a motivação, moralidade e ética, tanto de seguidores quanto dos líderes, por meio da sobreposição dos interesses individuais aos coletivos (BURNS, 1978).

A liderança transformacional possui cinco componentes básicos: (1) carisma, (2) influência idealizada, (3) motivação inspiracional, (4) estimulação intelectual e (5) consideração individualizada (BASS, 1998). Contudo, a dimensão do carisma, baseada, fundamentalmente, na própria liderança carismática, não é considerada como um comportamento do líder transformacional por um grande número de autores (YUKL, 2006; WALUMBWA et al., 2008). De acordo com Gardner et al. (2010), os estudos sobre liderança carismática, transacional e transformacional representaram, na década de 90, as abordagens dominantes dos trabalhos publicados no The Leadership Quarterly.

A partir da reflexão sobre as proposições destas escolas, depreende-se que as teorias sobre liderança têm procurado não apenas esclarecer a natureza do fenômeno, mas, também, identificar fatores associados à sua efetividade. Dessa forma, as investigações se aproximam na busca pelos traços, comportamentos, habilidades, fontes de poder e aspectos situacionais que promovem ou favorecem o exercício do papel de líder, isto é, de agente capaz de influenciar seguidores a perseguir objetivos transformadores dos contextos em que atuam. Tal busca parte do pressuposto de que a liderança pode ser explicada e até mesmo favorecida por esse conhecimento, se aplicado ao desenvolvimento de líderes (YUKL, 2012).

Nos últimos anos, emergiu uma nova teoria, denominada liderança autêntica. Apesar de ainda estar em fase de desenvolvimento (NORTHOUSE, 2010), essencialmente, ela busca atender a demandas por uma liderança mais ética e mais efetiva (LUTHANS; AVOLIO, 2003). 


\section{2. \\ Liderança Autêntica}

\subsection{1.}

\section{Histórico da Liderança Autêntica}

Um dos construtos mais estudados pelos pesquisadores nos últimos anos é o da liderança autêntica (GARDNER et al., 2010). Essa nova teoria, pautada em ideias da filosofia e da psicologia positiva (YUKL, 2006), busca analisar e discutir a genuinidade da liderança. Além disso, com os ataques de 11 de setembro, escândalos corporativos e crises econômicas e sociais, principalmente nos Estados Unidos, foram criadas demandas por líderes mais éticos, transparentes e de alto padrão moral (COOPER et al., 2005). Ainda segundo o autor, essa maior atenção dos gestores, proveniente de um ambiente de apreensão e insegurança, fez, então, com que pesquisas sobre líderes autênticos e seu desenvolvimento tivessem não só grandes implicações teóricas, mas, sobretudo, práticas (COOPER et al., 2005; AVOLIO et al., 2004; NORTHOUSE, 2010). Assim, com o intuito de atender tais demandas, a teoria da liderança autêntica foi proposta (LUTHANS; AVOLIO, 2003).

Discussões sobre o construto da autenticidade são encontradas desde a Grécia Antiga (HARTER, 2002; AVOLIO; GARDNER, 2005; WALUMBWA et al., 2008; GARDNER et al., 2011). Para Harter (2002), autenticidade está ligada com o compreender as próprias emoções, pensamentos, desejos, crenças e experiências. Seguindo essa vertente, compreende-se que este construto envolve a autoconsciência do indivíduo e, também, sua ação alinhada à sua própria personalidade, por intermédio da expressão de suas crenças e valores verdadeiros (LUTHANS; AVOLIO, 2003). Ademais, vale esclarecer que a autenticidade deve ser encarada como um continuum e não como um conceito dicotômico, de ser ou não autêntico (GARDNER et al., 2011).

Os primeiros debates sobre autenticidade na liderança começaram com a publicação de Bass e Steidlmeiers (1999) que abordam a denominada liderança transformacional autêntica (GARDNER et al., 2011). Nesse sentido, cabe se atentar, primeiramente, que a liderança autêntica possui, desde sua origem, muitos pontos de interseção com as ideias concebidas para a teoria da liderança 
transformacional (GEORGE, 2003; COOPER et al., 2005; WALUMBWA et al., 2008). Entretanto, para George (2003), a liderança autêntica se difere da transformacional ao não englobar necessariamente a dimensão do carisma. Por sua vez, segundo Avolio e Gardner (2005), a principal diferença entre os construtos reside no fato de que líderes autênticos possuem plena consciência de quem são e de seus valores e crenças, enquanto que líderes transformacionais não são dotados desta característica.

Os primeiros trabalhos na teoria dissertavam sobre suas raízes, conceitos e possíveis formas de mensuração (AVOLIO; GARDNER, 2005). Estes estudos seminais enfatizam também muitas das características presentes em um líder autêntico. Por exemplo, para Shamir e Eilam (2005), líderes autênticos possuem quatro atributos: (1) suas atividades desempenhadas são frutos de seus verdadeiros valores, (2) eles atingiram um auto grau de confiança em suas próprias crenças, (3) suas metas estão alinhadas com seus pensamentos e (4) seus comportamentos expressam bastante sua verdadeira natureza. Ou seja, para Shamir e Eilam (2005), o foco de um líder autêntico, resumidamente, era a autoconsciência.

Outro exemplo é o trabalho de Avolio e Gardner (2005) que discute mais profundamente a teoria, buscando diferenciá-la dos construtos anteriores de liderança. Os autores também promovem uma descrição detalhada do conceito, ilustrando o status de suas pesquisas e proporcionando diversos insights para futuros estudos, com destaque também na forma positiva deste construto. Já o trabalho de Cooper et al. (2005) busca trazer reflexões sobre o passado, repensando potenciais desafios e aprendizados que devem ser notados para o desenvolvimento da teoria. Por sua vez, Avolio et al. (2004), buscam, por meio da proposição de um modelo, realizar criar uma ponte entre o que sabe conceitualmente e empiricamente sobre o impacto de líderes autênticos nas atitudes e comportamentos dos seguidores. Ou seja, é objetivado desenvolver e analisar profundamente a maneira de influência de líderes autênticos. Um último exemplo é o trabalho seminal de Ilies et al. (2005) que por meio de um modelo complementar, demonstrando como os processos ocorridos por meio de uma liderança autêntica promovem o bem-estar de todos.

Partindo desses entendimentos, é possível observar a grande abrangência do construto, refletido, também, no grande número de conceituações existentes. Em uma de suas definições iniciais, Begley (2001, p. 353) afirma que "liderança 
autêntica pode ser pensada como uma metáfora para práticas profissionais eficazes, eticamente aceitáveis, e conscientemente reflexivas na administração educacional. Esta liderança é pautada no conhecimento, nos valores informados e em uma hábil execução". No sentido dessa ótica, já é possível observar alguns elementos que remontam a ideia de uma liderança que lide, concomitantemente, com um alto desempenho no contexto do trabalho e com um, no mínimo, padrão ético aceitável. Sob uma ótica mais recente, Walumbwa et al. (2008, p. 94), explicam o construto da seguinte forma:

"Liderança autêntica é definida como um padrão de comportamento do líder que se baseia e promove tanto as capacidades psicológicas positivas quanto um clima ético positivo, para buscar uma autoconsciência, uma perspectiva moral internalizada, um processamento balanceado de informações e uma transparência relacional na interação do trabalho de líderes e seguidores, procurando um autodesenvolvimento positivo" (WALUMBWA et al., 2008, p. 94).

Nesse sentido, os autores vão além ao propor quatro comportamentos basilares em líderes autênticos. O primeiro deles, referente ao autoconhecimento significa compreender suas próprias qualidades e fraquezas, assim como considerar, avaliar, e reformular sua própria atuação por meio do feedback gerado pelos seus seguidores (WALUMBWA et al., 2010). Ou seja, líderes autênticos devem ter plena clareza no sentido de saber quem são, o que intentam, como se comportam, para onde estão indo e qual é a coisa mais apropriada a se fazer (GEORGE, 2003; AVOLIO et al., 2004).

O segundo elemento é concernente a uma perspectiva moral internalizada, o que implica dizer que o líder não age de acordo com pressões organizacionais, hierárquicas ou quaisquer outras determinações externas. O líder age somente conforme seus próprios valores, por meio de seu próprio julgamento do que é certo ou errado (GARDNER et al., 2005). O terceiro item diz respeito ao processamento balanceado de informações, que na visão de Walumbwa et al. (2010) significa analisar, de forma equilibrada, o maior número de informação relevante disponível antes de tomar qualquer decisão. Ademais, líderes que possuem essa característica buscam, via de regra, a participação e o aconselhamento de outros indivíduos nestes processos de tomada de decisão. Por fim, a transparência relacional se refere a expressar e partilhar de forma aberta 
sentimentos, pensamentos e, até mesmo, informações relevantes quando no trato com outras pessoas (WALUMBWA et al., 2008).

Outro ponto importante da definição proposta por Walumbwa et al. (2008) é a promoção, por parte de líderes autênticos, das capacidades psicológicas positivas. Em seu estudo, Luthans e Avolio (2003) identificaram quatro atributos positivos que influenciam o comportamento desses líderes, a saber: (1) confiança, (2) esperança, (3) otimismo e (4) resiliência. Segundo Northouse (2010), todos estes atributos presentes em indivíduos podem ser traços inatos ou apenas estados efêmeros. Ou seja, eles podem representar características fixas da personalidade (imutáveis) ou apenas determinações contextuais que com treinamento e aconselhamento podem ser modificadas (NORTHOUSE, 2010).

De acordo com Luthans e Avolio (2003), confiança é concernente à auto eficácia, isto é, crer que algum indivíduo é capaz de realizar determinadas metas e objetivos. A esperança diz respeito a um estado emocional que está essencialmente pautado na força de vontade do indivíduo e no planejamento das metas. Por sua vez, o otimismo se relaciona com a visualização do lado positivo das situações, assim como a criação de expectativas benéficas sobre ações futuras. Por último, a resiliência se refere ao modo como os indivíduos lidam com as situações adversas, ou seja, se estes são capazes de se recuperar rapidamente e/ou de se tornar flexíveis para a transposição dessas situações. Portanto, líderes com essas características seriam capazes de desenvolver uma liderança mais positiva do ponto de vista humano e, inclusive, com um maior desempenho organizacional (LUTHANS; AVOLIO, 2003).

Por fim, um último aspecto de interessante debate presente na conceituação de Walumbwa et al. (2008) diz respeito a criação, por intermédio do comportamento do líder, de um clima ético positivo na organização. Líderes autênticos são capazes de abrir mão de seus interesses pessoais e, por meio do discernimento do que é certo e errado, agir eticamente em prol de interesses dos grupos, organizações e/ou comunidades (NORTHOUSE, 2010). Sem dúvida, o conceito de ética é central para esse tipo de liderança (COOPER et al., 2005) e tem sido cada vez mais abordada, tanto por teóricos quanto por executivos (CIULLA, 1995). Portanto, para se criar um ambiente positivo do ponto de vista ético, importa-se atentar para uma maior valorização da moralidade do líder do 
que para seus feitos e resultados, ao contrário do que é remontado pela história (CIULLA, 2003).

Apesar de o construto da liderança autêntica se encontrar ainda em suas fases iniciais de desenvolvimento (YUKL, 2006; WALUMBWA et al., 2008; NORTHOUSE, 2010) as pesquisas sobre o tema já apresentam algumas contribuições, tanto no que diz respeito ao entendimento do fenômeno quanto no que se refere a sua aplicação prática (NORTHOUSE, 2010). Por exemplo, o trabalho bibliográfico de Gardner et al. (2011) apresenta importantes contribuições para visualização de seu cenário atual. Este estudo de revisão da literatura encontrou, até dezembro de 2010, 91 publicações sobre o tema. Por outro lado, dentre os achados, observou-se que a maior parte das publicações são estudos apenas teóricos, demonstrando, assim, uma carência por mais estudos empíricos e práticos que busquem uma melhor operacionalização da teoria. Ademais, apontou-se, também, que $74,8 \%$ dos autores que publicam na área são oriundos dos Estados Unidos (GARDNER et al., 2011).

No Brasil, são vistos poucos estudos abordando o tema. A partir disso, dentre os encontrados, o trabalho de Cavazotte et al. (2013) contribui para a indicação de que líderes autênticos estão associados com uma melhor percepção de justiça, por parte dos trabalhadores e, também, com um maior desempenho em segurança no contexto laboral. Outro estudo, de Eboli et al. (2012), utilizou uma amostra brasileira para evidenciar que a liderança autêntica e a orientação para resultados estão positivamente relacionadas com o alto desempenho dos trabalhadores. Nesse sentido, os resultados da pesquisa de Vilas Boas et al. (2011) corroboram com os encontrados em Eboli et al. (2012), confirmando a ideia de que liderança autêntica está, de fato, associada com forte desempenho de seguidores, inclusive, por intermédio de algumas variáveis mediadoras, como: justiça interacional e comportamentos criativos.

Para futuros trabalhos, o corpo teórico da liderança autêntica possui alguns desafios a sobrepor. Em primeiro lugar, faz-se necessário desenvolver mais estudos empíricos sobre o tema, inclusive, em diversos contextos e sob a mediação de outras variáveis, como forma de expandir a aplicação e o entendimento do construto (NORTHOUSE, 2010). Nesse sentido, desenvolver, também, pesquisas utilizando métodos mais heterogêneos e rigorosos podem ser importantes direcionamentos para a construção de pesquisas futuras mais robustas 
(GARDNER et al., 2011). Ademais, cabe ressaltar, por fim, a relevância de investigar o papel do seguidor autêntico no processo de desenvolvimento da liderança autêntica, como um potencial agente influenciador deste fenômeno (AVOLIO; REICHARD, 2008; GARDNER et al., 2011).

\section{3. \\ Os seguidores}

\subsection{1.}

\section{Histórico e Importância dos Seguidores}

Na visão de alguns, a palavra "seguidores" não é possível de ser aplicada ao contexto de organizações e grupos, uma vez que ela, historicamente, possuiu fortes conotações políticas (ROST, 1991). De acordo com Challef (1995), o conceito de seguidor apresenta uma forte concepção negativa, geralmente associada a características tais como: conformidade, fraqueza e passividade. Nesse escopo, nota-se que o sentido da palavra faz referência a determinadas ideias pejorativas, conotando que seguidores não seriam capazes de agir inteligentemente e de serem produtivos sem o comando e o direcionamento de outros (ROST, 1991).

Em boa parte da literatura de liderança, principalmente até a metade do século XX, seguidores eram vistos como indivíduos submissos e passivos enquanto que líderes eram vistos como diretivos e ativos no processo (ROST, 1991). Pesquisadores na área de liderança geralmente não tratavam os atributos de seguidores como inputs no processo, mas sim como resultados ocasionados pelo fenômeno (AVOLIO et al., 2009). A partir desse entendimento, observa-se que, apesar de estar inerentemente associado ao contexto social e organizacional, o "papel de seguir" não estava presente no pensamento das pessoas. Sendo assim, a natureza, as características e a importância dos seguidores no desenvolvimento da liderança eram negligenciadas (KELLEY, 1988).

$\mathrm{O}$ que tem sido visto nas pesquisas mais recentes é que seguidores são pessoas extremamente ativas no processo da liderança (KELLEY, 1988; BASS, 2008; BANDURA, 1986; CHALLEF, 1995). Tanto assim que seguidores e líderes frequentemente transitam bidirecionalmente em seus papéis. Ou seja, na maioria dos casos, pessoas que são líderes em determinados contextos são seguidores em 
outros e vice versa. Inclusive, seria humanamente impossível conceber um indivíduo realizando uma função de liderança em inúmeros contextos simultaneamente. Portanto, conclui-se que a liderança não é formada somente pelo líder, mas sim pelo relacionamento entre os agentes (ROST, 1991).

Com base nessas ideias, Shamir (2007) aponta que a efetividade de uma liderança é tanto produto de bons seguidores quanto é de bons líderes, assim como o fato de que para se tornar bons seguidores, os indivíduos devem, de forma geral, possuir as mesmas qualidades de bons líderes (KELLEY, 1988). Nessa vertente, a literatura cita diversas características que poderiam ser atribuídas a seguidores efetivos. Primeiramente, para Challef (1995), seguidores efetivos dispõem de coragem, responsabilidade e pró-atividade. Kelley, por outro lado, afirma que estes devem apresentar entusiasmo, inteligência, honestidade, sinceridade e autonomia. Bass (2008) complementa, afirmando que a efetividade de um seguidor estaria associada a sua competência, autogestão e, inclusive, a uma elevada moralidade no cumprimento das atividades organizacionais. Por fim, Bandura (1986) resume essas ideias, tratando-os como agentes inteligentes que tentam ativamente entender e moldar seus ambientes.

Um ponto fundamental nesta discussão é o de que são os seguidores que dão legitimidade a um determinado líder. Eles que o empoderam e que, geralmente, o provê de meios para concretizar sua visão e seus objetivos (BROWN, 2012). Nesse sentido, segundo Meindl et al. (1985), a liderança é consideravelmente resultante do modo que os seguidores constroem seus entendimentos em relação ao líder. Isto é, como eles interpretam as personalidades, comportamentos e desempenho dos líderes. Portanto, o fenômeno estaria essencialmente pautado em seu reconhecimento por parte dos seguidores, assim como no grau de identificação para com o líder (BASS, 2008).

Essa maneira pela qual os seguidores enxergam um líder possui importantes implicações para o processo e, também, para a organização. Por exemplo, quando um líder é percebido como eficaz e competente por seguidores, é mais provável que ele receba promoções e cresça dentro da empresa, enquanto que quando o líder é visto como incompetente, é mais provável que seja substituído (YUKL, 2012). Sob essa ótica, compreende-se que seria mais importante, então, ser percebido como efetivo por seguidores do que, de fato, o ser. 
A literatura de seguidores e sua relação com a liderança autêntica já apresenta alguns resultados. Dentre estes, Gardner et al. (2005) evidenciaram que o desenvolvimento de líderes e seguidores com características de autenticidade, assim como a construção de relacionamentos autênticos, seriam bastante facilitados por um clima ético positivo. Nesse sentido, foi visto, também, por Cianci et al. (2014) que indivíduos, em geral, praticam mais ações antiéticas quando se há uma tentação do que quando não há. Da mesma forma, foi observado que quando se há uma tentação, a liderança autêntica reduziu significativamente a chance de seguidores se comportarem se maneira antiética.

Por outro lado, muitas lacunas na teoria ainda permanecem. Tendo isso em vista, para o desenvolvimento de futuros trabalhos, Avolio e Reichard (2008) enalteceram a importância de se investigar empiricamente o papel que seguidores desempenham na formação de relacionamentos autênticos. Nessa vertente, Shamir (2007) acrescentou recomendações referentes à necessidade de se examinar de que forma as expectativas, valores e atitudes dos seguidores influenciam o comportamento de um líder e a natureza da liderança.

\subsection{3.}

\section{Seguidores x Efetividade do Líder Autêntico}

Pesquisas têm demonstrado que a efetividade do líder é determinada por diversos aspectos, influenciando, de forma interconectada, na maneira como os seguidores enxergam esse desempenho. (LORD; MAHER, 1991; AWANLEH; GARDNER, 1999). Apesar disso, Yukl (2012) aponta que, geralmente, seguidores julgam não somente a competência do líder, mas, também, suas intenções. Nesse sentido, líderes que parecem estar mais preocupados com o desenvolvimento de seguidores e com a realização de uma missão do que com vantagens pessoais e desenvolvimento de carreira obterão um aceite maior dos seguidores. Ou seja, um líder que realiza, por exemplo, um serviço em prol da organização, praticando visíveis auto sacrifícios, tende a ser caracterizado como muito mais comprometido e confiável (YUKL, 2012).

Hogg, Hains e Mason (1998) complementam essa discussão, afirmando que essa avaliação da efetividade do líder é ainda mais forte e positiva quando o líder apresenta características específicas que são também valorizadas por seus seguidores (e.g. determinados valores, crenças e/ou ideais). Assim, quanto mais 
similaridade de valores houver entre líder e seguidores, maior será a percepção por parte destes últimos de um líder representativo, legítimo e efetivo.

\subsection{4.}

\section{Seguidores x Identidade com o Líder Autêntico}

O comportamento despendido por seguidores em um grupo ou organização pode ser, pelo menos em parte, explicado pelas suas identidades próprias e sociais (LORD; BROWN, 2004). Dessa forma, Carsten et al. (2010) observaram a forma com que estas identidades auxiliam na percepção que seguidores possuem acerca do líder. Também é explorada a maneira a qual seguidores obedecem ou resistem as tentativas de influência propostas pelos líderes.

Seguindo essa proposta e tendo como base o discutido na subseção anterior, seguidores valoram seus líderes em diferentes intensidades, muitas vezes, pautados no grau de similaridade de características e de identidades entre eles. Seguidores que tem uma identificação forte com uma organização ou grupo são mais prováveis de atribuir mais confiança em um líder que seja bem representativo de suas valorações e, até mesmo de sua personalidade, fazendo assim, mais atribuições favoráveis sobre o líder (HOGG; HAINS; MASON, 1998).

Por fim, cabe ressaltar, ainda, que além da personalidade, alguns outros fatores podem ter, também, efeito na maneira como seguidores enxergam os líderes com alto grau de autenticidade (YUKL, 2012), como é o caso da cultura ocupacional, a ser discutido na seção seguinte.

\section{4 .}

\section{A Influência da Área Ocupacional na Valoração do Líder}

A cultura ocupacional representa um nível intermediário de influência dentro do ambiente organizacional. Ela possui proporções menores do que a cultura organizacional, que permeia a todos, mas, ao mesmo tempo, representa mais do que a grande diversidade de valores individuais (O'HIGGINS; KELLEHER, 2005). Nesse contexto, gestores funcionais podem apresentar diferentes crenças e comportamentos perante questões éticas, conforme a área em que está inserido. Ou mais, as subculturas funcionais presentes na empresa podem ser culminantes no processo de influência, tendo grande poder de moldar 
indivíduos para agir conforme os valores daquela área (JOHNSON; SCHOLES, 2002).

Cada departamento funcional possui suas próprias experiências, pressões responsabilidades e papéis. Assim, cada função se relaciona com conjuntos específicos de stakeholders (WEISS, 2003). Além disso, dentro de um mesmo departamento, os indivíduos levam para o trabalho diferentes características e experiências pessoais, como a influência da família, da escola e de amigos (TSALIKIS; FRITZCHE, 1989; WILEY, 1998). Portanto, espera-se que a alteração desses inúmeros elementos provoque também uma diversidade de pontos de vista acerca de questões morais e éticas, moldando assim os grupos funcionais intraorganizacionais. Ou seja, estas diferenças subculturais gerariam novas perspectivas de trabalho, que poderiam, ainda ser aumentadas e reforçadas por meio das atividades laborais diárias e do feedback positivo constante (O’HIGGINS; KELLEHER, 2005).

Nesse sentido, este último elemento supracitado pressupõe um ponto muito relevante neste processo: o papel dos líderes funcionais. Muitas vezes, as obrigações em se agir de determinada forma são determinadas de forma deliberada pelos exemplos e discursos dos superiores formais na empresa (BADARACCO; WEBB, 1995). Na maioria dos casos, como forma de obter uma referência, empregados e subordinados das diversas posições observam o comportamento do líder para entender o que constituiria comportamentos aceitáveis e inaceitáveis dentro daquela função (WEISS, 1977).

Partindo deste ponto, é cabível compreender que, em especial, as áreas de Marketing/Vendas e de Finanças podem ser muito diferentes entre elas, mesmo quando presentes na mesma organização. Da mesma forma, elas apresentariam peculiaridades diversas quando comparadas com todas as outras áreas da empresa. Assim, por entender que estas áreas são extremamente relevantes, principalmente no referente ao grande envolvimento monetário, para quaisquer organizações, elas tendem a apresentar maiores dilemas morais e éticos (O’HIGGINS; KELLEHER, 2005). Além disso, como a alta moralidade é uma perspectiva da liderança autêntica (WALUMBWA et al. 2008), espera-se que, talvez, líderes dessas áreas, com mais condutas antiéticas, sejam menos autênticos. Com isso, para se melhor embasar sobre as atividades, pressões e responsabilidades diárias destas áreas, elas serão mais destacadas e aprofundadas nesta discussão. 


\subsection{1.}

\section{A área de Marketing}

A área de Marketing tem originado, por meio de suas atividades, muitos casos de condutas antiéticas, chegando a ser considerado como o pior "criminoso" das atividades dos negócios (DUNFEE et al., 1999). Inclusive, na academia, as preocupações com as práticas éticas da função de marketing têm sido reforçadas com publicação de inúmeros artigos científicos sobre o tema (BAUMHART, 1961; CHONKO; HUNT, 1985; MURPHY; LACZNIAK, 1981; TSALAKIS; FRITZSCHE, 1989).

Os profissionais dessa área procuram, constantemente, a maximização de receitas e tentam, deliberadamente, estar sempre à frente da concorrência. $\mathrm{Na}$ maioria dos casos, a mensuração do desempenho nesta área é feita com base no número de vendas, no aumento da participação de mercado e no atendimento de metas econômicas em geral. Com isso, pressões como estas podem levar a problemas éticos e, até mesmo, legais (WEISS, 2003).

Além disso, a área de marketing lida com diversos stakeholders, envolvendo diversas responsabilidades: compra e gestão de produtos, negociação com canais de distribuição, gestão de força de vendas, fornecimento e divulgação ampla, articulação internacional, entre outros (MURPHY; LACZNIAK, 1981). Por meio dessas responsabilidades, os profissionais de marketing agem compilando informações, conduzindo pesquisas de mercado, criando produtos, estabelecendo preços para eles, promovendo-os e distribuindo-os. Assim, muitas vezes, surgem dilemas éticos no concernente à segurança, à publicidade, à venda, à fixação de preços ou ao interagir com outros elementos do canal de distribuição que levam o produto requerido do fabricante até o consumidor final (FERREL et al., 2000). Ademais, estas preocupações podem ainda ser agravadas dependendo do próprio comportamento dos líderes funcionais em questão (WEISS, 1977).

\subsection{2.}

\section{A área de Finanças}

A área de finanças tem sido responsável por grandes escândalos anunciados nos últimos anos em diversas organizações. Os problemas que se sucederam, por exemplo, na Enron e na WorldCom não teriam ocorrido sem a participação dos 
profissionais de finanças, sejam eles quais forem: diretores, auditores internos e externos, bancos de investimentos e analistas (O’HIGGINS; KELLEHER, 2005). Inclusive, estes escândalos contaram com a participação de grandes lideranças. Tanto que, muitos desses acontecimentos provocaram reflexões no ambiente empresarial e acadêmico, originando o desenvolvimento de teorias de liderança mais éticas, como a própria liderança autêntica (NORTHOUSE, 2010).

A área tem tanta relevância para o negócio e sua reputação que, para assegurar o bom andamento da gestão financeira, muitas empresas declaram publicamente o envolvimento com práticas de governança e de ética cada vez mais rigorosas. Até porque os profissionais de finanças têm como obrigação gerir ativos para outros indivíduos, como acionistas (BOATRIGHT, 1999). Nesse sentido, geralmente, os gerentes se responsabilizam por relatar boas ou más notícias para a comunidade financeira. Com isso, eles podem ser incentivados por seus superiores a passar uma imagem favorável do desempenho financeiro, procurando brechas contábeis. Além disso, a crescente complexidade das transações e regras contábeis facilitam a ocorrência de fraudes financeiras, uma vez que muitos dos leitores destes relatórios não entenderiam completamente estas manobras (MILITELLO; SCHWALBERG, 2003).

Para Ferrel et al. (2000), frequentemente, a própria maneira de obter e utilizar recursos na área de finanças pode gerar dilemas éticos e legais. Além disso, posições financeiras empresariais são comunicadas a diversos stakeholders, contendo documentos com informações que podem levar investidores e terceiros a tomarem decisões que envolvam milhões de dólares. Assim, se estes documentos apresentarem, de forma intencional ou não, informações com pouca clareza e inexatas, o resultado pode levar a diversas ações judiciais e enquadramento em muitos crimes penais.

$\mathrm{Na}$ academia, são encontradas muitas pesquisas sobre a conduta ética de profissionais de finanças (VEIT; MURPHY, 1996; PONEMON, 1990; MCPHAIL, 2001). Veit e Murphy (1996) descobriram que 29,4\% dos profissionais de finanças já haviam sido solicitados a fazerem algo que acreditavam ser antiético, sendo que destes profissionais, $89 \%$ foram coagidos a isso por seus superiores. Ponemon (1990) argumenta que o grande problema do profissional de finanças é querer agradar o CEO. Nesse sentido, ele também afirma que este fato é ainda pior quando o CEO é antiético, ressaltando a 
importância do líder nesse processo. Por fim, McPhail (2001) descreve técnicas de gestão desumanizadoras que prevalecem nas áreas de contabilidade e finanças. O autor salienta que esse tipo de profissional tende a realizar quantificação e categorização, tratando indivíduos em termos quantitativos, minimizando sentimentos e colocando certo elementos importantes como meros objetos sem valor. Além disso, foi enfatizado o distanciamento do profissional de finanças, que, muitas vezes, por não estar face-a-face com outros acaba provocando um egocentrismo e ostracismo.

Como forma de fechar essa discussão, cabe citar o estudo de O'Higgins e Kelleher (2005). Ao comparar a perspectiva ética de profissionais de $\mathrm{RH}$, Marketing e Finanças, os autores evidenciaram que tanto marketing quanto finanças obtiveram resultados piores do que aqueles encontradas para a área de recursos humanos. Outro achado foi o de que não houve diferença na atribuição ética entre os próprios profissionais de marketing e de finanças. Portanto, tendo isto em vista e estando consciente do fato de que a ética é central na liderança autêntica (COOPER et al., 2005) e a moralidade se apresenta como uma importante vertente dela (WALUMBWA et al. 2008), o presente estudo apresenta seis hipóteses a serem testadas.

As primeiras três hipóteses são referentes à identificação com o líder. Busca-se testar se profissionais de marketing (H1) e de finanças (H2) se identificam menos com um líder autêntico do que profissionais de outras áreas (Recursos Humanos, Tecnologia da Informação, Pesquisa \& Desenvolvimento, Logística, Gestão de Projetos etc.). Da mesma forma, busca-se depreender se profissionais de marketing e de finanças apresentam diferenças na identificação com um líder autêntico (H3). Estas hipóteses são expostas a seguir:

H1: Profissionais de Marketing se identificam menos com um líder autêntico do que profissionais de outras áreas.

H2: Profissionais de Finanças se identificam menos com um líder autêntico do que profissionais de outras áreas.

H3: Profissionais de Marketing e de Finanças não se diferenciam na identificação com um líder autêntico. 
Por sua vez, as últimas três hipóteses deste primeiro experimento são concernentes à percepção de efetividade do líder. Busca-se testar se profissionais de marketing (H4) e de finanças (H5) veem um líder autêntico como menos efetivo do que profissionais de outras áreas (Recursos Humanos, Tecnologia da Informação, Pesquisa \& Desenvolvimento, Logística, Gestão de Projetos etc.). Da mesma forma, busca-se depreender se profissionais de marketing e de finanças apresentam diferenças na percepção de efetividade para com um líder autêntico (H6). Estas hipóteses são expostas a seguir:

H4: Profissionais de Marketing veem um líder autêntico como menos efetivo do que profissionais de outras áreas.

H5: Profissionais de Finanças veem um líder autêntico como menos efetivo do que profissionais de outras áreas.

H6: Profissionais de Marketing e de Finanças não se diferenciam na percepção de efetividade de um líder autêntico.

A partir das hipóteses desenvolvidas acima, foi estruturado um modelo proposto para o primeiro experimento (figura 1).

Figura 1 - Modelo Proposto do Experimento 1

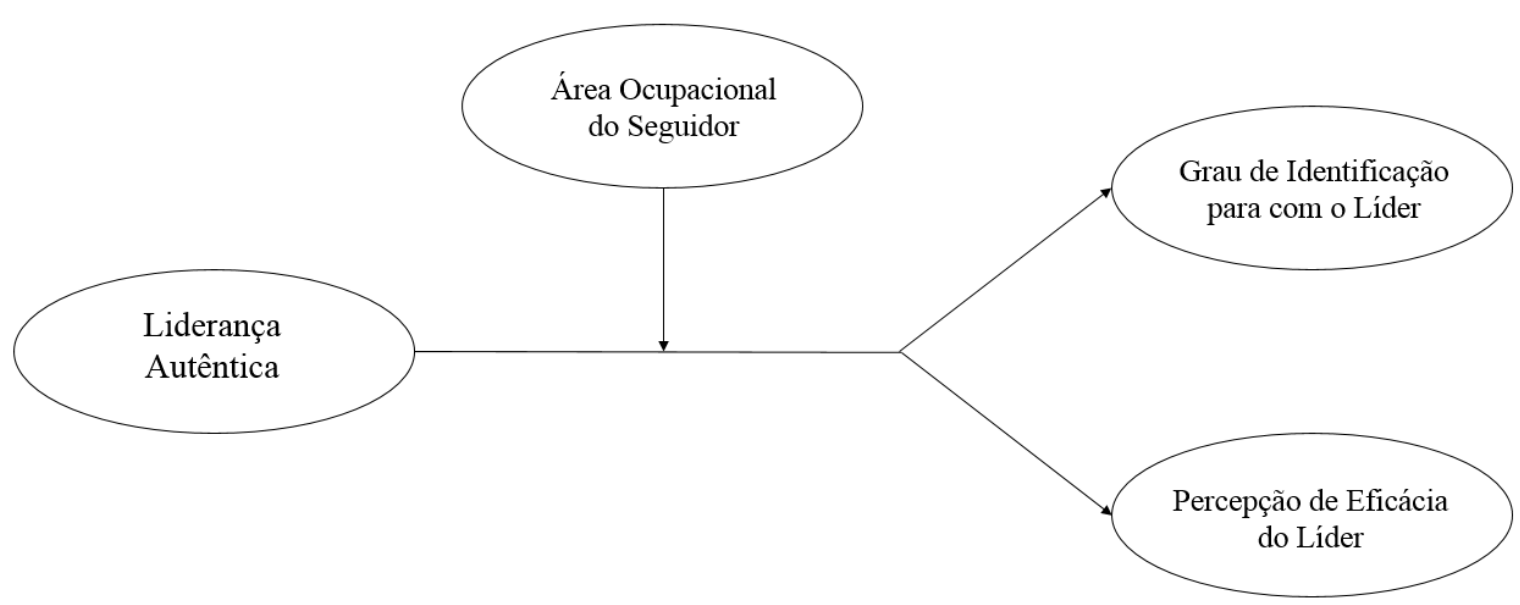

Fonte: Elaborado pelo autor. 


\section{5.}

\section{A Influência das emoções na Valoração do Líder}

\subsection{1.}

\section{Emoções e sua Importância para a Liderança}

Ao longo da literatura, pode-se encontrar diversas definições para emoções (FRIJDA, 2000). Por exemplo, segundo George (1996) emoções seriam intensos sentimentos que são direcionados a uma determinada pessoa ou coisa. Frijda, Manstead e Bem (2000), por sua vez, são mais abrangentes com o termo, afirmando que emoções podem ser vistas como estados mentais que englobam sentimentos, mudanças fisiológicas, comportamentos expressivos e inclinações a ação. Com base nisso, para alguns autores, emoções são caracterizadas como respostas mentais (IZARD, 1991; ORTONY; CLORE; COLLINS, 1988). Para outros, elas devem ser vistas como um traço, estado ou mistura dos dois (RAJAH; SONG; ARVEY, 2011) e/ou, também, referir-se a comportamentos, estados e experiências (LEWIS, 2000).

Emoções possuem curta duração, são voltadas a um alvo específico e são mais intensas que o humor (FRIJDA, 1993; FISHER, 2002). Ou seja, emoções são reações transitórias intensas a um evento, pessoa ou entidade (GOHN; CLORE, 2002). Além disso, há inúmeras expressões universais de emoção, que podem variar desde altamente negativas, como raiva e tristeza, até fortemente positivas, como felicidade e otimismo (EKMAN, 1997). Nesse sentido, elas são capazes de não só aumentar a percepção de um indivíduo como também auxiliar no entendimento de fatos, eventos, pessoas e o mundo em geral (CASSELL, 2002; FRIJDA; MANSTEAD; BEM, 2000; OAKLEY, 1992).

$\mathrm{Na}$ literatura de liderança, elas também têm recebido bastante atenção (GOOTY et al., 2010). Pesquisadores já as reconhecem como centrais para a compreensão das experiências no ambiente laboral e se interessam pelo estudo de seus impactos nas tomadas de decisão e nos estilos de liderança, além de outros temas (RAJAH; SONG; ARVEY, 2011). Contudo, este ainda é visto como um tópico complexo, uma vez que diversos fatores afetam a expressão de emoções de um indivíduo. Sendo assim, regulações sociais, normas ou, até mesmo, regras informais de uma organização poderiam ocasionar o estímulo a expressão ou a 
supressão de determinadas emoções, por meio de sua permissão ou não de serem transmitidas e compartilhadas abertamente (SUTTON; RAFAELI, 1998).

Dessa forma, é possível conceber que, nas interações sociais diárias entre líderes e seguidores, os primeiros enfrentam, além das tarefas inerentes ao trabalho, o desafio adicional de gerenciar suas emoções, de forma efetiva, para serem capazes de inspirar e motivar seguidores em suas ações (BERSON; AVOLIO, 2004). Tanto assim, que emoções são, atualmente, entendidas como preditores de desempenho (BRIEF; WEISS, 2002) e como influenciadores na maneira pela qual líderes são percebidos e avaliados a partir de suas emoções expressadas (MADERA; SMITH, 2009).

Seguindo esta perspectiva, a influência das emoções na valoração da liderança tem sido evidenciada em diferentes estudos (NEWCOMBE; ASHKANASY, 2002; GADDIS; CONNELLY; MUMFORD, 2004; BONO; ILLIES, 2006; LEWIS, 2000; MONTEPARE; DOBISH, 2003). Em alguns destes trabalhos foi visto que a expressão de emoções positivas por líderes está positivamente relacionada com boas avaliações do líder e sua maior atratividade (e.g. NEWCOMBE; ASHKANASY, 2002; BONO; ILLIES, 2006) enquanto que outros evidenciaram que expressões de emoções negativas do líder tendem a provocar uma pior avaliação por seus subordinados de seu desempenho no trabalho (e.g. GADDIS; CONNELLY; MUMFORD, 2004; LEWIS, 2000).

Um dos primeiros trabalhos nessa linha, realizado por Newcombe e Ashkanasy (2002) mostrou que, quando a afetividade do líder está alinhada com sua mensagem passada, ele é percebido como sincero e genuíno. Dessa forma, para um líder receber avaliações mais positivas, por seus seguidores, de sua liderança, ele deve expressar um afeto positivo acompanhado de um feedback igualmente positivo. Após esta pesquisa, surgiu o trabalho de Gaddis, Connelly e Mumford (2004) com achados similares. Os autores descobriram que, durante falhas no feedback, líderes foram avaliados como mais efetivos quando eles apresentaram um afeto positivo do que quando apresentaram um afeto negativo. Ademais, foi também observado que grupos possuíam um desempenho inferior quando o líder expressava emoções negativas.

Bono e Illies (2006), por sua vez, trabalharam com um ator treinado, que manipulou o afeto do líder por meio da expressão de emoções positivas ou neutras (sem emoções), proporcionando, assim, diversos achados. Nesse estudo, os 
autores observaram que expressões emocionais positivas do líder resultaram em maior afetividade positiva em seguidores, e que esta afetividade positiva dos seguidores conduz, a avaliações mais positivas do líder. Sendo assim, os resultados indicaram que a condição emocional positiva do líder gera uma experiência afetiva positiva em subordinados e, consequentemente, uma melhor percepção e avaliação de sua efetividade.

O estudo de Lewis (2000) usou um método similar, gravando discursos em vídeos que manipulavam o gênero e a emocionalidade expressada pelo líder. Nesse estudo, foi percebido que pessoas que viram um líder triste reportaram menos entusiasmo e mais fadiga quando comparados àqueles que viram um líder neutro. Por outro lado, indivíduos que viram um líder com raiva reportaram mais nervosismo e menos relaxamento do que quando viram um líder neutro. Sendo assim, o líder neutro ainda foi mais bem avaliado em efetividade do que líderes com raiva ou tristes.

Tendo em vista que esses estudos sugeriram o impacto das emoções do líder na afetividade e nas percepções dos seguidores, parece importante investigar a forma com que ocorre o contágio das emoções entre líderes e seguidores, já que este seria um ponto nevrálgico a esta discussão (CHERULNIK et al., 2001; HUMPHREY, 2008). Reforçando essa ideia, George (1996, p. 162) expõe que "líderes que demonstram excitação, entusiasmo e atividade têm maior probabilidade de energizar seus subordinados e transmitir um sentido de eficácia, competência, otimismo e satisfação". Por outro lado, Kelly e Barsade (2001) afirmam que a indução de afeto pode, às vezes, levar a transferência de emoções diferentes do remetente para o recebedor, não havendo, assim, o contágio sempre da mesma emoção.

Nesse sentido, alguns estudos aprofundaram a questão do contágio emocional (SY; SAAVEDRA; CÔTÉ, 2005; GROSSMAN, 2000; ILLIES et al., 2009; WEISS; CROPANZANO, 1996). Por exemplo, a investigação de Sy, Saavedra e Côté (2005) demonstrou que membros de um grupo desenvolvem um humor mais positivo quando líderes também apresentam esse mesmo comportamento, sugerindo que essa influência se dá pelo contágio de emoções entre os agentes. Ademais, os trabalhos de Illies et al. (2009) e Weiss e Cropanzano (1996) argumentam que o afeto positivo do líder proporciona um ambiente laboral mais positivo, gerando, assim, um alto encorajamento para 
melhorar a produção. Dessa forma, são invocadas mais emoções positivas nos subordinados que resultam em uma melhoria de seus recursos cognitivos e que, então, os auxiliam no melhor desempenho, no trabalho, de suas atividades.

Outro ponto é o de que ao expressarem as emoções vistas como apropriadas por seguidores, líderes são mais prováveis de desenvolver bons relacionamentos, a partir da empatia (LEWIS, 2000; DAVIS, 1994) o que os ajudariam, ainda, a serem legitimados e percebidos como mais efetivos (RAJAH; SONG; ARVEY, 2011) neste fenômeno do contágio emocional.

\subsection{2.}

\section{A Positividade e Negatividade das Emoções na Liderança}

No processo da liderança, tanto líderes quanto seguidores sentem e expressam diversas emoções (MCCOLL-KENNEDY; ANDERSON, 2002). Conforme já mencionado, há um grande número de expressões de emoções, que podem ser divididas em dois tipos: emoções positivas, como esperança e otimismo, e emoções negativas, como tristeza e pessimismo (EKMAN, 1997). Nesse sentido, a diferença entre estes tipos estaria relacionada com um resultado mais benéfico ou prejudicial ao contexto. Por exemplo, a expressão de emoções positivas em líderes pode criar um ambiente harmônico, promovendo sentimentos bons em seguidores (MADERA; SMITH, 2009), inspirando-os e motivando-os (BASS, 1990; CONGER; KANUNGO, 1994). Assim, a positividade das emoções estaria associada com os benefícios psicossociais e emocionais resultados de seu emprego, enquanto que a negatividade produziria reações inversas.

Uma das emoções positivas mais discutidas na literatura de liderança é o otimismo, e diversos trabalhos expõem sua importância e seus benefícios (BANDURA, 1977; STRUTTON; LUMPKIN, 1993; SCHULMAN, 1999; MCCOLL-KENNEDY; ANDERSON, 2002). Nessa ordem de ideias, Bandura (1977) declara que, conforme propõe a própria teoria da auto-regulação, pessoas tendem a se esforçar mais para alcançar objetivos quando elas se sentem otimistas. Dessa forma, é exposto também pelo autor que sua antítese, o pessimismo, pode, muitas vezes, ocasionar em esforço reduzido de colaboradores. McColl-Kennedy e Anderson (2002) complementam essa vertente, sugerindo que algumas organizações já têm, inclusive, utilizado o otimismo como uma forma de distinção entre indivíduos de baixo e elevado desempenho. 
Segundo Schulman (1999), pessoas otimistas apresentam diversas características positivas. Elas olham o mundo diferentemente, veem sempre desafios nas adversidades, transformam em oportunidades os reveses da vida, investem no aprimoramento de habilidades e capacidades pessoais, perseveram na busca de soluções de problemas de difícil resolução, são extremamente persistentes e se recuperam rapidamente de obstáculos e problemas que enfrentam.

Embora haja mais estudos investigando emoções positivas comparados àqueles que tratam de emoções negativas (GOOTY et al., 2010), alguns trabalhos se debruçaram sobre uma delas: a frustração. Por exemplo, McColl-Kennedy e Anderson (2002) testaram os efeitos tanto do otimismo quanto da frustração do líder no desempenho de subordinados, trabalhando com líderes transformacionais no contexto da indústria farmacêutica. Dentre seus achados, perceberam que ambas emoções são mediadoras do relacionamento entre liderança transformacional e desempenho. Foi visto que níveis baixos de características transformacionais do líder podem prejudicar a performance dos trabalhadores, a partir do aumento da frustração. Ademais, observou-se que a influência negativa da frustração no desempenho dos empregados tem um efeito mais negativo do que a influência positiva do otimismo, denotando-se, com isso, a necessidade maior de se investigar os potenciais impactos da expressão de emoções negativas.

Além deste, outros estudos fazem associações entre as emoções e os estilos liderança preconizados, principalmente no referente às teorias da liderança transformacional e transacional (CONNELY; RUARK, 2010; ASHKANASY; TSE, 2000). Contudo, poucos fazem referência à influência das emoções na percepção da autenticidade de um líder, conforme discorrido na teoria proposta por Avolio et al. (2004). Como nessa teoria a positividade é um elemento essencial, parece importante investigar empiricamente seus efeitos.

O modelo proposto por Avolio et al. (2004), que analisa a relação entre liderança autêntica e atitudes e comportamentos de seguidores, ressalta os potenciais efeitos que emoções positivas e a confiança teriam no processo da liderança autêntica. Inclusive, Lord e Brown (2004) afirmam que, geralmente, as teorias anteriores de liderança focaram muito mais em elementos cognitivos do que em processos afetivos e emocionais. Por isso, o trabalho de Avolio et at. (2004) tentou realizar essa ponte, analisando a possível relação da liderança 
autêntica com o otimismo, esperança e emoções positivas em geral, sugerindo que elas mediariam os relacionamentos de identificação dos seguidores para com o líder.

O trabalho de Michie e Gooty (2005) também sugere a importância das emoções para esta liderança, oferecendo um número adicional de emoções específicas que poderiam distinguir líderes autênticos de inautênticos. Nesse sentido, quando líderes experienciam estas outras emoções positivas (e.g. boa vontade, gratidão, preocupação com outros etc.), eles agem com valores mais autotranscendentes, favorecendo assim, comportamentos igualmente autotranscendentes. Então, a capacidade do líder em apresentar tais emoções poderia aumentar não só as percepções de autenticidade como, também, promover uma identificação com o líder e outros stakeholders da organização.

Portanto, as emoções são tão importantes para a liderança autêntica, que elas são vistas como responsáveis por proporcionar às pessoas informações sobre as personalidades e características individuais e, também, sobre as várias transações dinâmicas que os indivíduos compartilham no ambiente organizacional. Além disso, líderes autênticos seriam capazes de aumentar a confiança, contagiando seguidores com estados e emoções positivas e promovendo, assim, o bem-estar e o forte engajamento de toda a força de trabalho da organização (AVOLIO et al., 2004).

Sendo assim, buscando atender à necessidade exposta por Dasborough e Ashkanasy (2002) e Howell e Shamir (2005), este trabalho avalia o efeito de emoções positivas, neutras e negativas na percepção de eficácia e na identificação com o líder. Ou seja, com bases nas ideias expostas nesta seção, propõem-se, por meio de hipóteses, que seguidores veem líderes autênticos com emoções positivas como mais eficazes do que os mesmos líderes com emoções negativas ou neutras. De forma similar, seguidores veriam como mais eficazes líderes autênticos de emoções neutras do que um que apresentasse somente emoções negativas.

H7: Seguidores veem como mais efetivo um líder autêntico com emoções positivas do que um líder com emoções neutras.

H8: Seguidores veem como mais efetivo um líder autêntico com emoções positivas do que um líder com emoções negativas. 
H9: Seguidores veem como mais efetivo um líder autêntico com emoções neutras do que um líder com emoções negativas.

Portanto, seguindo essa vertente, semelhantes efeitos seriam visualizados quando analisado o grau de identificação dos seguidores para com o líder. Ou seja, seguidores se identificam mais com um líder autêntico com emoções positivas do que com os mesmos líderes com emoções neutras ou negativas. Ademais, sob essa ótica, seguidores também se identificariam mais com um líder autêntico com emoções neutras do que um líder com emoções negativas.

H10: Seguidores se identificam mais com um líder autêntico com emoções positivas do que um líder com emoções neutras.

H11: Seguidores se identificam mais com um líder autêntico com emoções positivas do que um líder com emoções negativas.

H12: Seguidores se identificam mais com um líder autêntico com emoções neutras do que um líder com emoções negativas.

A partir das hipóteses desenvolvidas acima, foi estruturado um modelo proposto para o experimento (figura 2).

Figura 2 - Modelo Proposto do Experimento 2

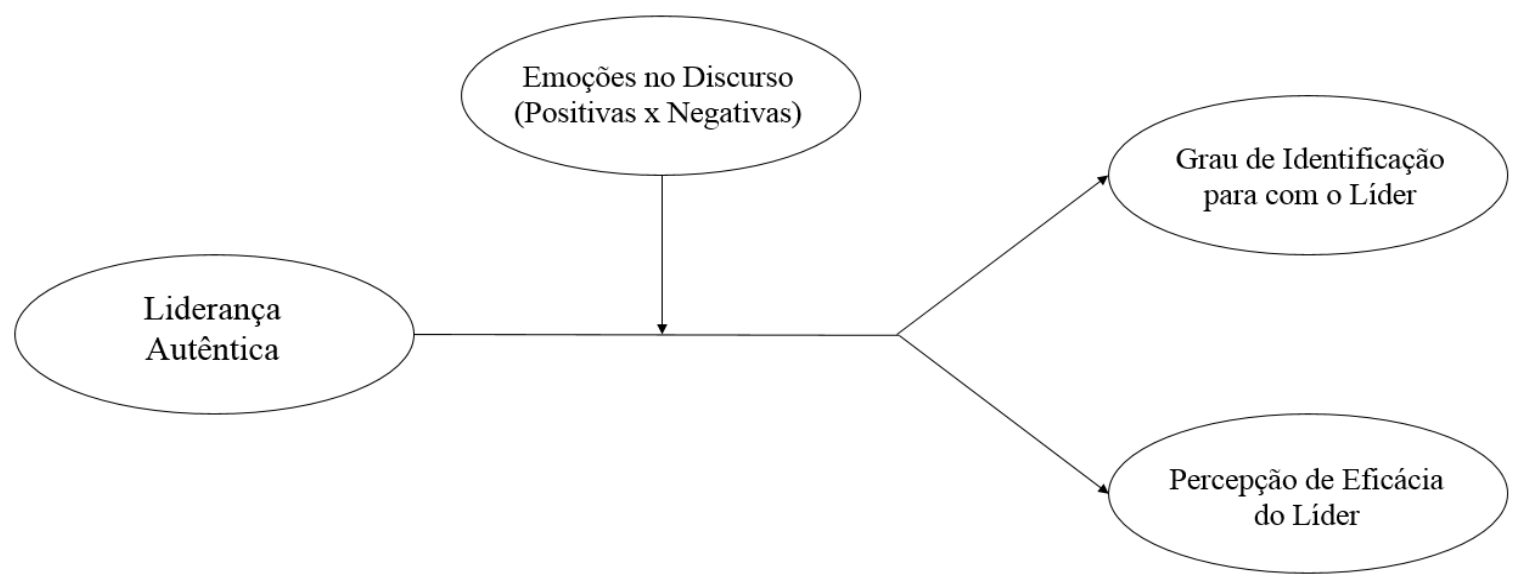

Fonte: Elaborado pelo autor 


\section{3 \\ Experimento 1}

\section{1.}

\section{Método do Estudo}

\subsection{1.}

\section{Procedimento}

Esta pesquisa buscou identificar se líderes que esposam valores autênticos são percebidos como líderes mais efetivos, promovendo uma maior identificação entre seus seguidores e sendo avaliados como mais eficazes. Também foi objetivo deste experimento verificar se a área ocupacional (marketing, finanças e outras) está associada ao julgamento sobre o líder.

Primeiramente, foram desenvolvidos os instrumentos necessários para a realização do experimento. Um ator profissional foi contratado com o objetivo de gravar vídeos em que a autenticidade do líder foi manipulada. No vídeo de controle, o CEO de uma empresa fictícia apresenta a companhia para novos funcionários (controle). Ao segmento de apresentação da empresa do vídeo de controle foi acrescentado posteriormente os discursos correspondentes às condições experimentais 1 e 2 . No vídeo experimental 1 (discurso autêntico), em acréscimo ao segmento de apresentação da empresa, o líder endossa valores autênticos. No vídeo experimental 2 (discurso inautêntico), em acréscimo ao segmento de apresentação da empresa, o líder endossa valores inautênticos.

O texto do discurso autêntico proferido pelo ator foi desenvolvido com base nas subdimensões da liderança autêntica operacionalizadas na escala criada por Walumbwa et al. (2008) (Questionário de Liderança Autêntica (ALQ). Distribuído por Mind Garden, Inc. www.mindgarden.com). Os atributos autênticos mensurados pelo instrumento foram adaptados sob a forma de afirmações no discurso do líder, atentando-se para manter a naturalidade nas falas. O inverso foi feito no discurso inautêntico, onde princípios opostos aos autênticos foram adaptados sob a forma de afirmações no discurso do líder, tomando-se as mesmas precauções anteriormente mencionadas (ver Apêndice 1). O vídeo de controle tem a duração de 1:02 minutos e os experimentais 1 e 2, respectivamente 1:49 e 1:52. O cenário de fundo, idêntico nos três vídeos, remete a uma suíte executiva. 


\subsection{2.}

\section{Amostra}

As hipóteses expostas na seção 2.4 foram verificadas em uma amostra composta por 271 profissionais que atuam em empresas de variados tipos. Esses profissionais são, atualmente, estudantes de MBA e Mestrado Profissional em duas diferentes universidades situadas no Rio de Janeiro.

Destes 271 respondentes, 133 eram homens (49,10\%) e 138 mulheres $(50,90 \%)$. A idade média deles era de 32,30 anos $(\mathrm{DP}=7,21)$ e o tempo de área médio era de 7,96 anos ( $\mathrm{DP}=6,27)$. Os participantes assistiram a um dos três vídeos, o vídeo de controle e ou em um dos dois vídeos experimentais (discurso autêntico e inautêntico). O número total de participantes no grupo experimental 1 (apresentação da empresa e discurso autêntico), controle (apresentação da empresa) e experimental 2 (apresentação da empresa e discurso inautêntico) foi de, respectivamente, 74, 86 e 111 profissionais. Os dados amostrais por área ocupacional do respondente e por vídeo assistido podem ser visualizados detalhadamente na tabela 1 , a seguir:

Tabela 1 - Dados Amostrais dos Participantes por Área Ocupacional e Vídeo Assistido

\begin{tabular}{|c|c|c|c|c|c|c|c|c|c|}
\hline Área & Variável & \multicolumn{2}{|c|}{ Autêntico } & \multicolumn{2}{|c|}{ Neutro } & \multicolumn{2}{|c|}{ Inautêntico } & \multicolumn{2}{|c|}{ Total } \\
\hline \multirow{4}{*}{ Outras } & Sexo & $71,4 \% \mathrm{~F}$ & $28,6 \% \mathrm{M}$ & $46,9 \% \mathrm{~F}$ & $53,1 \% \mathrm{M}$ & $56,4 \% \mathrm{~F}$ & $43,6 \% \mathrm{M}$ & $57,1 \% \mathrm{~F}$ & $42,9 \% \mathrm{M}$ \\
\hline & Idade & \multicolumn{2}{|c|}{$\bar{x}=33,57 ; \mathrm{DP}=9,03$} & \multicolumn{2}{|c|}{$\bar{x}=34,41 ; \mathrm{DP}=8,24$} & \multicolumn{2}{|c|}{$\bar{x}=33,36 ; \mathrm{DP}=7,42$} & \multicolumn{2}{|c|}{$\bar{x}=33,71 ; \mathrm{DP}=7,93$} \\
\hline & Tempo Área & \multicolumn{2}{|c|}{$\bar{x}=8,63 ; \mathrm{DP}=6,22$} & \multicolumn{2}{|c|}{$\bar{x}=8,90 ; \mathrm{DP}=6,82$} & \multicolumn{2}{|c|}{$\bar{x}=9,33 ; \mathrm{DP}=6,92$} & \multicolumn{2}{|c|}{$\bar{x}=9,06 ; \mathrm{DP}=6,70$} \\
\hline & Participantes & \multicolumn{2}{|c|}{21 Profissionais } & \multicolumn{2}{|c|}{32 Profissionais } & \multicolumn{2}{|c|}{55 Profissionais } & \multicolumn{2}{|c|}{108 Profissionais } \\
\hline \multirow{4}{*}{ MKT } & Sexo & $76,9 \% \mathrm{~F}$ & $23,1 \% \mathrm{M}$ & $50,0 \% \mathrm{~F}$ & $50,0 \% \mathrm{M}$ & $27,3 \% \mathrm{~F}$ & $72,7 \% \mathrm{M}$ & $52,9 \% \mathrm{~F}$ & $47,1 \% \mathrm{M}$ \\
\hline & Idade & \multicolumn{2}{|c|}{$\bar{x}=30,36 ; \mathrm{DP}=6,60$} & \multicolumn{2}{|c|}{$\bar{x}=29,86 ; \mathrm{DP}=5,15$} & \multicolumn{2}{|c|}{$\bar{x}=32,55 ; \mathrm{DP}=6,04$} & \multicolumn{2}{|c|}{$\bar{x}=30,90 ; \mathrm{DP}=6,01$} \\
\hline & Tempo Área & \multicolumn{2}{|c|}{$\bar{x}=6,42 ; \mathrm{DP}=6,13$} & \multicolumn{2}{|c|}{$\bar{x}=6,84 ; \mathrm{DP}=5,63$} & \multicolumn{2}{|c|}{$\bar{x}=9,33 ; \mathrm{DP}=6,39$} & \multicolumn{2}{|c|}{$\bar{x}=7,50 ; \mathrm{DP}=6,11$} \\
\hline & Participantes & \multicolumn{2}{|c|}{26 Profissionais } & \multicolumn{2}{|c|}{22 Profissionais } & \multicolumn{2}{|c|}{22 Profissionais } & \multicolumn{2}{|c|}{70 Profissionais } \\
\hline \multirow{4}{*}{ FIN } & Sexo & $40,7 \% \mathrm{~F}$ & $59,3 \% \mathrm{M}$ & $37,5 \% \mathrm{~F}$ & $62,5 \% \mathrm{M}$ & $50,0 \% \mathrm{~F}$ & $50,0 \% \mathrm{M}$ & $43,0 \% \mathrm{~F}$ & $57,0 \% \mathrm{M}$ \\
\hline & Idade & \multicolumn{2}{|c|}{$\bar{x}=31,41 ; \mathrm{DP}=7,15$} & \multicolumn{2}{|c|}{$\bar{x}=31,06 ; \mathrm{DP}=7,53$} & \multicolumn{2}{|c|}{$\bar{x}=32,56 ; \mathrm{DP}=6,28$} & \multicolumn{2}{|c|}{$\bar{x}=31,71 ; \mathrm{DP}=6,94$} \\
\hline & Tempo Área & \multicolumn{2}{|c|}{$\bar{x}=6,68 ; \mathrm{DP}=5,04$} & $\bar{x}=7,62$ & $\mathrm{DP}=6,68$ & $\bar{x}=6,93$ & $\mathrm{P}=5,62$ & $\bar{x}=7,09$ & $\mathrm{DP}=5,79$ \\
\hline & Participantes & 27 Prof & sionais & 32 Pro & & 34 Prof & sionais & 93 Prof & sionais \\
\hline & Sexo & $62,2 \% \mathrm{~F}$ & $37,8 \% \mathrm{M}$ & $44,2 \% \mathrm{~F}$ & $55,8 \% \mathrm{M}$ & $48,7 \% \mathrm{~F}$ & $51,3 \% \mathrm{M}$ & $50,9 \% \mathrm{~F}$ & $49,1 \% \mathrm{M}$ \\
\hline Total & Idade & $\bar{x}=31,67$ & $\mathrm{DP}=7,57$ & $\bar{x}=32,00$ & $\mathrm{DP}=7,46$ & $\overline{\bar{x}}=32,96$ & $\mathrm{DP}=6,78$ & $\bar{x}=32,30$ & $\mathrm{DP}=7,21$ \\
\hline & Tempo Área & $\bar{x}=7,1$ & $P=5,76$ & $\bar{x}=7,86$ & $\mathrm{DP}=6,44$ & $\bar{x}=8,5$ & $\mathrm{PP}=6,46$ & $\bar{x}=7,9 c$ & $\mathrm{P}=6,27$ \\
\hline & Participantes & 74 Prof & sionais & 86 Prof & ssionais & 111 Pro & ssionais & 271 Pro & issionais \\
\hline
\end{tabular}

Fonte: Elaborado pelo autor. 


\subsection{3.}

\section{Coleta de Dados}

Foi elaborado um questionário composto de três partes para a coleta dos dados do experimento (ver Apêndice 2). A primeira parte visou observar as atitudes dos participantes em relação ao líder do vídeo assistido, com perguntas tais como: "Eu gostaria de ter esse indivíduo como meu líder formal (chefe)" e "Eu me dedicaria mais e aumentaria minha produtividade com um líder como esse”. Em seguida, foi incluído o questionário de liderança autêntica, utilizado para avaliar o efeito da manipulação. Na segunda parte do questionário, foi solicitado aos participantes que respondessem a questões relativas aos seus dados demográficas, com a finalidade de levantar variáveis de controle e posteriormente descrever os participantes (sexo, idade, formação, tempo de empresa e de experiência).

O experimento foi realizado em 15 sessões de apresentação do vídeo do CEO, sendo 5 sessões do vídeo de controle, 5 sessões do vídeo experimental 1 e 5 sessões do vídeo experimental 2. No momento de realização do experimento, foi solicitado aos participantes que não conversassem com colegas e que mesmo depois da apresentação, evitassem comentar sobre a pesquisa até o término total da coleta de dados do estudo, com o intuito de evitar contaminações. Foi informado o tempo de duração estimado do experimento. Antes do vídeo, também foi informado que seria apresentado um vídeo de boas-vindas gravado pelo CEO de uma empresa para apresentar a companhia a novos funcionários. O tempo médio de duração do experimento (apresentação do vídeo e preenchimento do questionário) nas sessões foi de 15 minutos.

\subsection{4.}

\section{Escalas de Mensuração}

Percepção de Eficácia - Foram elaborados três itens que visam avaliar as atribuições dos seguidores sobre a efetividade do líder. Os itens que compõem está escala são: "Esse CEO é um bom líder", "Eu me dedicaria mais e aumentaria minha produtividade com um líder como esse" e "Eu acredito que esse líder teria um alto desempenho na área em que trabalho". Participantes avaliam suas percepções de eficácia por meio de uma escala Likert ( 1 = Discordo Totalmente, 5 
$=$ Concordo Totalmente). O Alpha de Cronbach da escala calculado para a amostra deste estudo foi de 0,833 .

Identificação com o Líder - Foram elaborados outros três itens que buscam identificar o grau de identificação do seguidor para com o líder. Assim sendo, os itens que compõem a escala são: "Esse CEO corresponde à imagem que eu tenho de um líder", "Eu me identifico com esse líder" e "Eu gostaria de ter esse CEO como líder formal (chefe)". Respondentes atribuem seu grau de identificação com o líder por intermédio de uma escala Likert $(1=$ Discordo Totalmente, $5=$ Concordo Totalmente). O Alpha de Cronbach da escala calculado para a amostra deste estudo foi de 0,901 .

Liderança Autêntica - Adotou-se a escala desenvolvida por Walumbwa et al. (2008) (Questionário de Liderança Autêntica (ALQ). Distribuído por Mind Garden, Inc. www.mindgarden.com). Essa métrica busca avaliar o grau de autenticidade do líder que é percebido pelos seguidores, sendo composta de 16 itens que refletem as quatro dimensões propostas pela teoria. Alguns exemplos de itens são: "O líder diz exatamente o que pensa" e "O líder admite quando comete erros". Participantes avaliam a frequência de determinados comportamentos do líder por meio de uma escala de cinco pontos $(1=$ nunca, $5=$ frequentemente, se não sempre). O Alfa de Cronbach original da escala é 0,84 e o calculado para a amostra deste estudo foi de 0,907 .

Dados Demográficos - Foram solicitados aos participantes que respondessem questões referentes a gênero, idade, organização onde trabalha, tempo de empresa e tempo de experiência. Estas perguntas foram utilizadas como controle para o experimento, como forma de garantir a homogeneidade dos grupos analisados.

\section{2.}

\section{Análise de Resultados - Experimento 1}

$\mathrm{Na}$ primeira etapa da análise, buscou-se testar o efeito da manipulação. Assim, foi verificado se a manipulação da variável autenticidade do líder obteve o efeito desejado, apresentando diferenças significativas entre os três vídeos. Para isso, foi feito um teste de análise da variância (ANOVA) e, posteriormente, um 
teste Post Hoc (tabela 2) com o objetivo de observar se os níveis de autenticidade do líder em cada um dos três grupos foram percebidos como, de fato, diferentes.

Os resultados da ANOVA indicaram, primeiramente, que houve uma diferença significativa no nível de autenticidade do líder nos três grupos ( $\mathrm{F}=$ 46,32, $\mathrm{p}<0,001)$. Dessa forma, como segunda etapa do exame, realizou-se um teste Post Hoc (Tukey HSD) visando proceder a comparações múltiplas entre os níveis de autenticidade do líder nos três grupos (controle, experimental 1 e 2). Os resultados indicaram que houve diferenças significativas entre os três grupos (Tabela 5). Ou seja, participantes que assistiram ao vídeo experimental 1 (discurso autêntico) reportaram média significativamente mais alta na autenticidade do líder $(\overline{\mathrm{x}}=3,37 ; \mathrm{DP}=0,74)$, seguido pelo grupo de controle $(\overline{\mathrm{x}}=2,92 ; \mathrm{DP}=0,69) \mathrm{e}$, por fim, pelo grupo que assistiu ao vídeo experimental 2 (discurso inautêntico), que apresentou médias significativamente mais baixas $(\overline{\mathrm{x}}=2,42 ; \mathrm{DP}=0,58)$, conforme detalhado abaixo.

Tabela 2 - ANOVA e Post Hoc para teste de Manipulação

\begin{tabular}{|c|c|c|c|c|c|c|}
\hline \multirow{2}{*}{\multicolumn{2}{|c|}{ Diferenças entre Grupos }} & \multicolumn{2}{|c|}{ ANOVA } & \multicolumn{3}{|c|}{ Comparação Múltipla (Tukey HSD) } \\
\hline & & $\mathrm{F}$ & Sigma & Diferença & DP & Sigma \\
\hline \multirow{2}{*}{ Neutro } & Autêntico & \multirow{6}{*}{46,32} & \multirow{6}{*}{0,000} & $-0,45^{*}$ & 0,11 &, 000 \\
\hline & Inautêntico & & & $0,50 *$ & 0,10 & ,000 \\
\hline \multirow{2}{*}{ Autêntico } & Neutro & & & $0,45^{*}$ & 0,11 &, 000 \\
\hline & Inautêntico & & & $0,95 *$ & 0,10 & ,000 \\
\hline \multirow{2}{*}{ Inautêntico } & Neutro & & & $-0,50 *$ & 0,10 & ,000 \\
\hline & Autêntico & & & $-0,95 *$ & 0,10 &, 000 \\
\hline
\end{tabular}

Obs: Variável dependente - Autenticidade do Líder

*Diferença entre médias significativa para um nível de 0,05 .

Após esta etapa, como forma de verificar a homogeneidade dos grupos, foram feitas análises da variância (ANOVAS) para as variáveis demográficas de controle: sexo $(F=2,79 ; p=0,063)$, idade $(F=0,81 ; p=0,447)$ e tempo de área $(\mathrm{F}=1,12 ; \mathrm{p}=0,328)$. Não foram encontradas diferenças sistemáticas entre os grupos para nenhuma das variáveis de controle. A seguir, são apresentadas as estatísticas descritivas e coeficientes de correlações calculados para a amostra total de participantes (tabela 3). 
Tabela 3 - Estatísticas Descritivas e Correlações para Amostra Total

\begin{tabular}{|c|c|c|c|c|c|c|c|c|c|c|}
\hline Variáveis & Média & DP & 1 & 2 & 3 & 4 & 5 & 6 & 7 & 8 \\
\hline 1. Sexo $(1=\mathrm{F} ; 2=\mathrm{M})$ & 1,49 & 0,50 & & & & & & & & \\
\hline 2. Idade & 32,30 & 7,21 &,- 05 & & & & & & & \\
\hline 3. Tempo de Área & 7,96 & 6,27 &, 04 &, $70^{* * *}$ & & & & & & \\
\hline 4. Finanças & 0,35 & 0,48 &, 12 &,- 07 &,- 10 & & & & & \\
\hline 5. Marketing & 0,26 & 0,44 &,- 02 &,$- 12^{*}$ &,- 04 &,$- 43 * *$ & & & & \\
\hline 6. Líder Autêntico & 0,27 & 0,45 &,$- 14 *$ &,- 05 &,- 08 &, 03 &, $13^{*}$ & & & \\
\hline 7. Líder Inautêntico & 0,41 & 0,49 &, 04 &, 08 & ,08 &,- 06 &,- 11 &,$- 51 * *$ & & \\
\hline 8. Percepção Eficácia & 2,52 & 1,02 & ,04 &,- 12 &,$- 12 *$ & ,09 &,- 01 &, $35^{* *}$ &,$- 38 * *$ & \\
\hline 9. Grau de Identificação & 2,26 & 1,11 &, 10 &,- 12 &,- 10 &, 07 &, 02 &, $40^{* *}$ &,$- 44 * *$ &, $84 * *$ \\
\hline
\end{tabular}

$\mathrm{N}=271 *$. $\mathrm{p}<0.05 * * . \mathrm{p}<0.01$

Fonte: Elaborado pelo autor 
Para esta análise dos coeficientes de correlações foram criadas dummies, sendo duas delas referente ao líder autêntico e ao líder inautêntico (grupos experimentais 1 e 2). Também houve dummies para as áreas: Finanças e Marketing. A partir dos resultados é possível observar que a área de marketing apresentou correlação negativa com idade $\left(\mathrm{R}=-0,12^{*}\right)$ e com a área de finanças $\left(\mathrm{R}=-0,43^{* *}\right)$. Também é possível observar que os escores de homens foram menores do que os de mulheres nas avaliações do líder no grupo experimental 1 (líder autêntico) $\left(\mathrm{R}=-0,14^{*}\right)$. As avaliações de autenticidade do líder no grupo experimental 1 e 2 apresentaram correlação negativa $(\mathrm{R}=-0,51 * *)$. No que diz respeito às variáveis de interesse, a percepção de eficácia apresentou correlação negativa com tempo de área $\left(\mathrm{R}=-0,12^{*}\right)$ e no grupo experimental 2 (líder inautêntico) $\left(\mathrm{R}=-0,38^{* *}\right)$ e correlação positiva com o grupo experimental 1 (líder autêntico) $\left(\mathrm{R}=0,35^{* *}\right)$. Por último, o grau de identificação para com o líder obteve correlação negativa com o grupo experimental 2 (líder inautêntico) $(\mathrm{R}=$ $\left.0,44^{* *}\right)$, enquanto que houve forte correlação positiva com o grupo experimental 1 (líder autêntico) $\left(\mathrm{R}=0,40^{* *}\right)$ e com a percepção de eficácia $\left(\mathrm{R}=0,84^{* *}\right)$.

Após esta fase, buscou-se analisar o efeito do discurso sobre as variáveis dependentes de interesse. Então, foi feito, primeiro, uma ANOVA para o grau de identificação (Tabela 4), onde os resultados mostraram uma diferença significativa no grau de identificação com o líder entre os grupos $(F=41,79 ; p<$ 0,001). Como segunda etapa dessa análise, realizou-se um teste Post Hoc (Tukey HSD) visando proceder comparações múltiplas entre os níveis de identificação para verificar em quais grupos as médias foram, de fato, diferentes. A partir dessa análise, foram observadas diferenças significativas entre todos os grupos (Autêntico: $\bar{x}=3,01$; DP $=0,12$; Neutro: $\bar{x}=2,38$; DP $=0,11$; Inautêntico: $\bar{x}=1,73$; DP $=0,10)$. Ainda, observou-se que quando o efeito da área ocupacional é analisado separadamente, independente do vídeo assistido, não houve diferenças significativas na identificação com o líder $(\mathrm{F}=0,71 ; \mathrm{p}=0,491)$. Por outro lado, ao analisar a área ocupacional como elemento moderador do efeito do discurso (Discurso*Área) a diferença entre os grupos passou a ser significativa para um nível de $0,5(\mathrm{~F}=2,50 ; \mathrm{p}=0,043)$. Com isso, foi observado que o grau de identificação com os líderes nas três condições (controle, autêntico e inautêntico) variou sistematicamente em função da área ocupacional do participante. 
Tabela 4 - ANOVA e teste Post Hoc para efeito do Discurso na Identificação

\begin{tabular}{|c|c|c|c|c|c|c|}
\hline \multirow{2}{*}{\multicolumn{2}{|c|}{ Diferenças entre Grupos }} & \multicolumn{2}{|c|}{ ANOVA } & \multicolumn{3}{|c|}{ Comparação Múltipla (Tukey HSD) } \\
\hline & & $\mathrm{F}$ & Sigma & Diferença & DP & Sigma \\
\hline \multirow{2}{*}{ Neutro } & Autêntico & \multirow{6}{*}{41,79} & \multirow{6}{*}{0,000} & $-0,59^{*}$ & 0,15 & ,001 \\
\hline & Inautêntico & & & $0,73^{*}$ & 0,14 & , 000 \\
\hline \multirow{2}{*}{ Autêntico } & Neutro & & & $0,59^{*}$ & 0,15 & , 001 \\
\hline & Inautêntico & & & $1,32 *$ & 0,15 &, 000 \\
\hline \multirow{2}{*}{ Inautêntico } & Neutro & & & $-0,73 *$ & 0,14 &, 000 \\
\hline & Autêntico & & & $-1,32^{*}$ & 0,15 &, 000 \\
\hline
\end{tabular}

Obs: Variável dependente - Grau de Identificação

*Diferença entre médias significativa para um nível de 0,05 .

Em seguida, foi feita outra ANOVA para se analisar o efeito do discurso sobre a percepção de eficácia do líder (Tabela 5). Os resultados evidenciaram que, assim como a identificação, houve diferenças na percepção de eficácia do líder entre os grupos $(\mathrm{F}=29,32 ; \mathrm{p}<0,001)$. Como segunda etapa do exame, realizou-se um teste Post Hoc (Tukey HSD) visando proceder comparações múltiplas entre os níveis para identificar em quais grupos as médias foram, de fato, diferentes. A partir dessa análise, foi encontrado que todos os grupos apresentaram diferenças significativas quando comparados entre eles (Autêntico: $\bar{x}=3,14$; DP $=0,11$; Neutro: $\bar{x}=2,60$; DP = 0,10; Inautêntico: $\bar{x}=2,13$; DP = 0,09). Ainda, observou-se que quando o efeito da área ocupacional é analisado separadamente, independente do vídeo assistido, não houve diferenças significativas na percepção de eficácia do líder $(\mathrm{F}=1,29 ; \mathrm{p}=0,278)$. Contudo, também foi percebido que, ao analisar a área como elemento moderador do discurso (Discurso*Área) a diferença entre os grupos passou a ser significativa para um nível de $0,01(\mathrm{~F}=3,57 ; \mathrm{p}=0,007)$. Com isso, é observado que somente o efeito da área não é fator responsável pela variação na percepção, mas que, indubitavelmente, há a influência da área moderando o efeito dos diferentes discursos na avaliação de eficácia dos líderes.

Tabela 5 - ANOVA e teste Post Hoc para efeito do discurso na Eficácia

\begin{tabular}{|c|c|c|c|c|c|c|}
\hline \multirow{2}{*}{ Diferenças entre Grupos } & \multicolumn{2}{|c|}{ ANOVA } & \multicolumn{2}{|c|}{ Comparação Múltipla (Tukey HSD) } \\
\cline { 5 - 7 } \multicolumn{2}{|c|}{} & F & Sigma & Diferença & DP & Sigma \\
\hline \multirow{2}{*}{ Neutro } & Autêntico & \multirow{4}{*}{29,32} & & $-0,49^{*}$ & 0,15 &, 003 \\
\cline { 5 - 6 } & Inautêntico & \multirow{3}{*}{0,000} & $0,57^{*}$ & 0,13 &, 000 \\
\hline \multirow{2}{*}{ Autêntico } & Neutro & & $0,49^{*}$ & 0,15 &, 003 \\
\cline { 2 - 4 } & Inautêntico & & $1,05^{*}$ & 0,14 &, 000 \\
\hline \multirow{2}{*}{ Inautêntico } & Neutro & & $-0,57^{*}$ & 0,13 &, 000 \\
\cline { 5 - 7 } & Autêntico & & $-1,05^{*}$ & 0,14 &, 000 \\
\hline
\end{tabular}

Obs: Variável dependente - Percepção de Eficácia

*Diferença entre médias significativa para um nível de 0,05 . 
Após esta etapa, com o intuito de melhor visualizar a diferença entre médias das variáveis de interesse para cada um dos grupos envolvidos, foi feita uma tabela resumo com os valores encontrados por tipo de líder assistido, por área a qual os profissionais pertencem e por variável de interesse (Tabela 6). A partir dos valores expostos nesta tabela é possível observar, inicialmente, que as médias encontradas para profissionais de Marketing e de Finanças são relativamente bem semelhantes entre elas. Entretanto, observa-se que profissionais de outras áreas foram mais sensíveis a essas avaliações. Ou seja, estes profissionais percebem o líder autêntico como tendo maior eficácia (Outras: $\overline{\mathrm{x}}=3,60$; $\mathrm{DP}=0,99$; Marketing: $\overline{\mathrm{x}}=2,83 ; \mathrm{DP}=0,80 ;$ Finanças: $\overline{\mathrm{x}}=2,98 ; \mathrm{DP}=0,87)$ e se identificam mais com ele (Outras: $\overline{\mathrm{x}}=3,45 ; \mathrm{DP}=1,26$; Marketing: $\overline{\mathrm{x}}=2,68 ; \mathrm{DP}=1,12$; Finanças: $\overline{\mathrm{x}}=2,90$; DP $=0,95)$ do que profissionais de Marketing ou de Finanças. Da mesma forma, os profissionais de outras áreas perceberam o líder inautêntico como tendo menor eficácia (Outras: $\overline{\mathrm{x}}=1,85 ; \mathrm{DP}=0,90$; Marketing: $\overline{\mathrm{x}}=2,18$; $\mathrm{DP}=1,13$; Finanças: $\overline{\mathrm{x}}=$ 2,34; $\mathrm{DP}=0,99$ ) e se identificam menos (Outras: $\overline{\mathrm{x}}=1,52 ; \mathrm{DP}=0,87$; Marketing: $\overline{\mathrm{x}}=$ 1,86; $\mathrm{DP}=1,03$; Finanças: $\overline{\mathrm{x}}=1,79 ; \mathrm{DP}=0,78$ ) do que profissionais de Marketing ou de Finanças. Portanto, pelas médias, profissionais de outras áreas são mais sensíveis na avaliação dos diferentes tipos de líderes, aceitando mais o líder autêntico e rejeitando mais o inautêntico do que profissionais de Marketing ou de Finanças.

Tabela 6 - Médias de Eficácia e Identificação por Grupos

\begin{tabular}{|c|c|c|c|c|c|c|}
\cline { 2 - 7 } \multicolumn{1}{c|}{} & \multicolumn{2}{c|}{ Autentico } & \multicolumn{2}{c|}{ Neutro } & \multicolumn{2}{c|}{ Inautêntico } \\
\cline { 2 - 7 } \multicolumn{1}{c|}{} & Eficácia & Identificação & Eficácia & Identificação & Eficácia & Identificação \\
\hline \multirow{2}{*}{ Marketing } & $\bar{x}=2,83 ;$ & $\bar{x}=2,68 ;$ & $\bar{x}=2,44 ;$ & $\bar{x}=2,26 ;$ & $\bar{x}=2,18 ;$ & $\bar{x}=1,86 ;$ \\
& $\mathrm{DP}=0,80$ & $\mathrm{DP}=1,12$ & $\mathrm{DP}=0,74$ & $\mathrm{DP}=0,79$ & $\mathrm{DP}=1,13$ & $\mathrm{DP}=1,03$ \\
\hline \multirow{2}{*}{ Finanças } & $\bar{x}=2,98 ;$ & $\bar{x}=2,90 ;$ & $\bar{x}=2,70 ;$ & $\bar{x}=2,51 ;$ & $\bar{x}=2,34 ;$ & $\bar{x}=1,79 ;$ \\
& $\mathrm{DP}=0,87$ & $\mathrm{DP}=0,95$ & $\mathrm{DP}=0,83$ & $\mathrm{DP}=1,04$ & $\mathrm{DP}=0,99$ & $\mathrm{DP}=0,78$ \\
\hline \multirow{2}{*}{ Outras } & $\bar{x}=3,60 ;$ & $\bar{x}=3,45 ;$ & $\bar{x}=2,67 ;$ & $\bar{x}=2,38 ;$ & $\bar{x}=1,85 ;$ & $\bar{x}=1,52 ;$ \\
& $\mathrm{DP}=0,99$ & $\mathrm{DP}=1,26$ & $\mathrm{DP}=0,94$ & $\mathrm{DP}=0,99$ & $\mathrm{DP}=0,90$ & $\mathrm{DP}=0,87$ \\
\hline
\end{tabular}

Fonte: Elaborado pelo autor

Com o objetivo de facilitar a compreensão e visualizar mais claramente os resultados supracitados, foram feitos gráficos para a comparação de médias entre os grupos. O primeiro compara as médias do grau de identificação por cada área ocupacional (Figura 3). Dessa forma, é possível observar a maior identificação para com o líder autêntico entre profissionais de outras áreas ocupacionais em 
comparação com os de marketing e finanças, que reportaram menor identificação com o líder autêntico e maior identificação com o líder inautêntico.

Figura 3 - Grau de Identificação por Áreas Ocupacionais

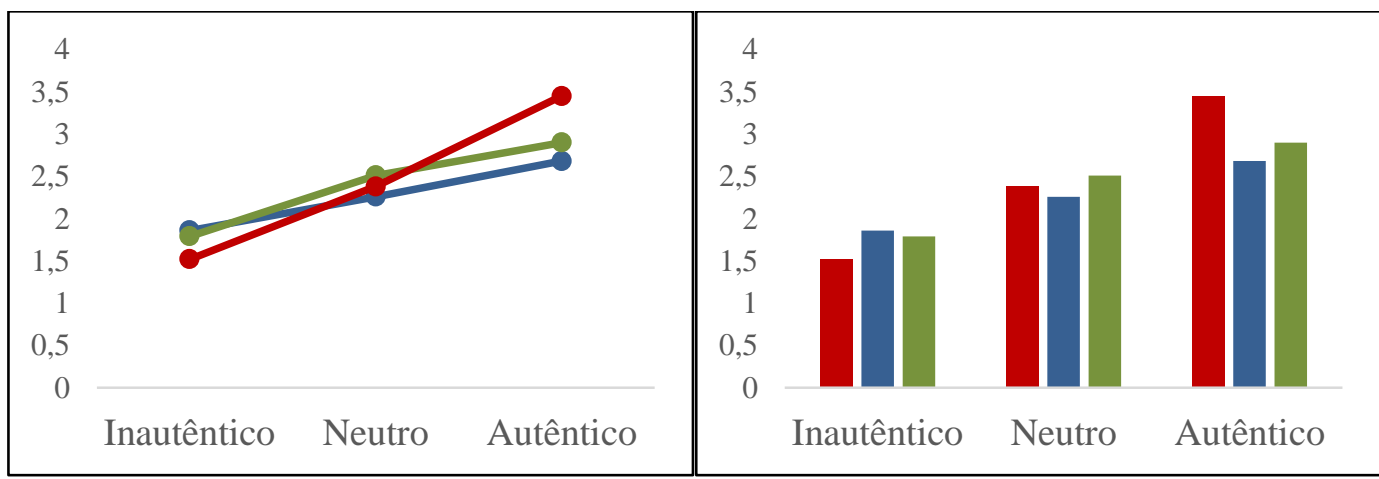

Finanças $\square$ Marketing $\square$ Outras Áreas

O segundo gráfico compara as médias na percepção de eficácia do líder em cada área ocupacional (Figura 4):

Figura 4 - Percepção de Eficácia por Áreas Ocupacionais

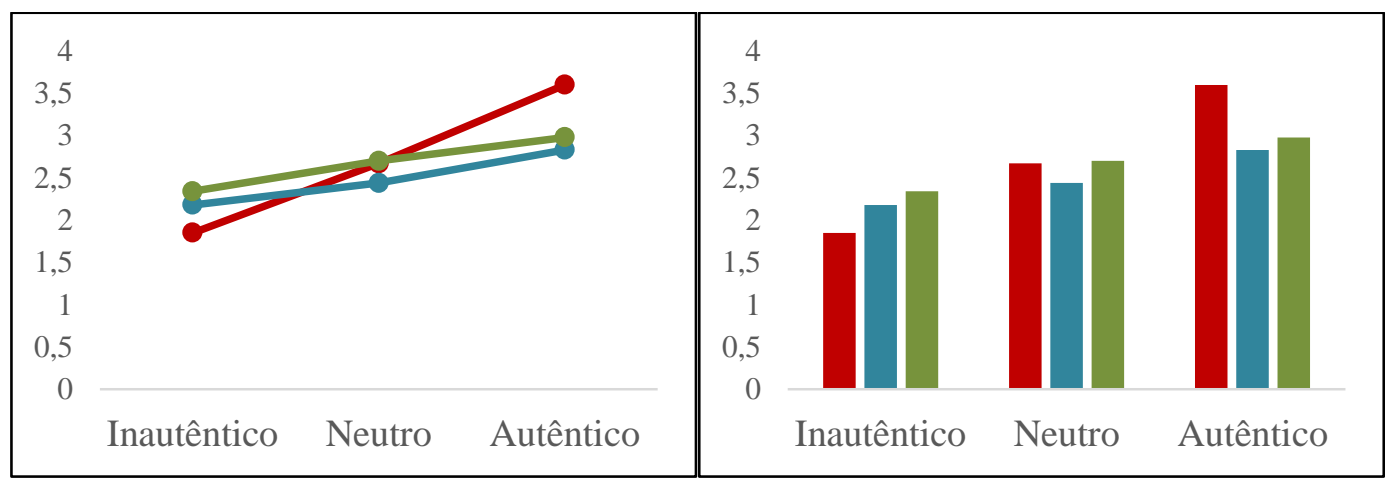

Finanças $\square$ Marketing $\square$ Outras Áreas

O passo seguinte da análise do experimento 1 foi a decisão de se analisar o efeito da área ocupacional nas percepções sobre o líder autêntico. Com isso, foi feito um filtro para selecionar os participantes que assistiram ao vídeo do experimento $1(\mathrm{~N}=74)$. Foram feitas ainda análises da variância (ANOVAS) para as variáveis demográficas de controle: idade $(\mathrm{F}=1,21 ; \mathrm{p}=0,304)$ e tempo de área $(\mathrm{F}=0,94 ; \mathrm{p}=0,396)$ entre os três grupos ocupacionais. Como não foram encontradas diferenças sistemáticas entre as áreas, os grupos foram considerados equivalentes. A seguir encontram-se as estatísticas descritivas e coeficientes de correlações para a amostra de participantes do líder autêntico (Tabela 7). 
Tabela 7 - Estatísticas Descritivas e Correlações para o grupo experimental 1 (Líder Autêntico)

\begin{tabular}{|c|c|c|c|c|c|c|c|c|c|}
\hline Variáveis & Média & DP & 1 & 2 & 3 & 4 & 5 & 6 & 7 \\
\hline 1. $\operatorname{Sexo}(1=\mathrm{F} ; 2=\mathrm{M})$ & 1,38 & 0,49 & & & & & & & \\
\hline 2. Idade & 31,67 & 7,57 & ,03 & & & & & & \\
\hline 3. Tempo de Área & 7,14 & 5,76 & ,16 &, $63 * *$ & & & & & \\
\hline 4. Finanças & 0,37 & 0,49 &, $35^{* *}$ &,- 03 &,- 06 & & & & \\
\hline 5. Marketing & 0,36 & 0,48 &,- 21 &,- 13 &,- 09 &,$- 57 * *$ & & & \\
\hline 6. Outras & 0,27 & 0,45 &,- 15 &, 18 &, 16 &,$- 47 * *$ &,$- 46 * *$ & & \\
\hline 7. Grau de Identificação & 2,98 & 1,13 &,- 09 &, 11 &, 04 &,- 05 &,- 19 & ,26 & \\
\hline 8. Percepção Eficácia & 3,11 & 0,92 &,- 09 &, 11 & ,04 &,- 10 &,- 21 &, $34 * *$ &, $87 * *$ \\
\hline
\end{tabular}

$\mathrm{N}=74 * . \mathrm{p}<0.05 * * . \mathrm{p}<0.01$

Fonte: Elaborado pelo autor 
A partir dos resultados é possível observar a forte correlação positiva entre tempo de área e idade $(\mathrm{R}=0,63 * *)$. Finanças apresentou forte correlação com sexo $\left(\mathrm{R}=0,35^{* *}\right)$. Já a variável "outras áreas" obteve forte correlação com as áreas de Finanças $(\mathrm{R}=-0,47 * *)$ e Marketing $\left(\mathrm{R}=-0,46^{* *}\right)$. A variável de interesse percepção de eficácia evidenciou correlações positivas com outras áreas $\left(\mathrm{R}=0,34^{* *}\right)$ e grau de identificação $\left(\mathrm{R}=0,87^{* *}\right)$.

Nesta etapa da análise, elaborou-se uma ANOVA, objetivando-se testar as três primeiras hipóteses (Tabela 8). A variável dependente era o grau de identificação dos seguidores com o líder autêntico. Ou seja, o intuito era, primeiramente, observar se há diferença no grau de identificação com um líder autêntico entre os profissionais das três diferentes áreas. Depois, observar se profissionais da área de Marketing se identificam menos com o líder autêntico do que profissionais de outras áreas (H1), assim como entender o mesmo para profissionais da área de Finanças (H2). Também buscou-se observar se profissionais de marketing e finanças se identificavam igualmente com um líder autêntico (H3). Tendo isso em vista, os resultados evidenciaram que não houve uma diferença significativa entre os graus de identificação dos grupos analisados $(\mathrm{F}=2,84 ; \mathrm{p}=0,065)$, conforme mais detalhadamente visualizado com o teste Post Hoc. Com isso, apesar da média absoluta de identificação de outras áreas ter sido maior do que as dos de Marketing e a de Finanças, esta diferença não foi significativa. Portanto, as hipóteses $\mathrm{H} 1$ e $\mathrm{H} 2$ foram rejeitadas e H3 confirmada.

Tabela 8 - ANOVA e Post Hoc para Identificação por Área (Líder Autêntico)

\begin{tabular}{|c|c|c|c|c|c|c|}
\hline \multirow{2}{*}{\multicolumn{2}{|c|}{ Diferenças entre Grupos }} & \multicolumn{2}{|c|}{ ANOVA } & \multicolumn{3}{|c|}{ Comparação Múltipla (Tukey HSD) } \\
\hline & & $\mathrm{F}$ & Sigma & Diferença & $\mathrm{DP}$ & Sigma \\
\hline \multirow{2}{*}{ Outras } & Marketing & \multirow{6}{*}{2,84} & \multirow{6}{*}{0,065} & 0,77 & 0,33 & 056 \\
\hline & Finanças & & & 0,55 & 0,33 & 219 \\
\hline \multirow{2}{*}{ Marketing } & Outras & & & $-0,77$ & 0,33 & 056 \\
\hline & Finanças & & & $-0,22$ & 0,30 &, 745 \\
\hline \multirow{2}{*}{ Finanças } & Outras & & & $-0,55$ & 0,33 & 219 \\
\hline & Marketing & & & 0,22 & 0,30 & .745 \\
\hline
\end{tabular}

Obs: Variável dependente - Grau de Identificação

*Diferença entre médias significativa para um nível de 0,05 .

Dando continuidade à análise de resultados, outra ANOVA foi desenvolvida, buscando testar as três últimas hipóteses referentes a este primeiro experimento (Tabela 9). A variável dependente era a percepção de efetividade do líder autêntico. Ou seja, o intuito era, primeiramente, observar se há diferença na 
percepção de eficácia de um líder autêntico entre os profissionais das três diferentes áreas. Depois, observar se profissionais da área de Marketing (H4) e Finanças (H5) veem como menos efetivo um líder autêntico do que profissionais de outras áreas. Também buscou-se observar se profissionais de marketing e finanças percebiam igualmente a efetividade do líder (H6). Tendo isso em vista, os resultados da ANOVA evidenciaram que, para um nível de significância de 0,05 , há uma diferença significativa na percepção de eficácia desse líder nos grupos analisados $(\mathrm{F}=4,70 ; \mathrm{p}=0,012)$. Em seguida, o teste Post Hoc revelou, inicialmente, que não houve diferença significativa de percepção de eficácia entre as áreas de Finanças e de Marketing. Contudo, tanto Marketing quanto Finanças apresentaram médias significativamente mais baixas do que as outras áreas, indicando que há uma diferença na maneira como profissionais de diferentes áreas avaliam a efetividade de líderes autênticos. Portanto, as hipóteses H4, H5 e H6 foram confirmadas.

Tabela 9 - ANOVA e teste Post Hoc para Eficácia por Área (Líder Autêntico)

\begin{tabular}{|c|c|c|c|c|c|c|}
\hline \multirow{2}{*}{\multicolumn{2}{|c|}{ Diferenças entre Grupos }} & \multicolumn{2}{|c|}{ ANOVA } & \multicolumn{3}{|c|}{ Comparação Múltipla (Tukey HSD) } \\
\hline & & $\mathrm{F}$ & Sigma & Diferença & DP & Sigma \\
\hline \multirow{2}{*}{ Outras } & Marketing & \multirow{6}{*}{4,70} & \multirow{6}{*}{0,012} & $0,77 *$ & 0,26 & 012 \\
\hline & Finanças & & & $0,62 *$ & 0,26 & 049 \\
\hline \multirow{2}{*}{ Marketing } & Outras & & & $-0,77^{*}$ & 0,26 & 012 \\
\hline & Finanças & & & $-0,14$ & 0,25 & ,826 \\
\hline \multirow{2}{*}{ Finanças } & Outras & & & $-0,62 *$ & 0,26 & ,049 \\
\hline & Marketing & & & 0,14 & 0,25 & ,826 \\
\hline
\end{tabular}

Obs: Variável dependente - Percepção de Eficácia

*Diferença entre médias significativa para um nível de 0,05 .

Por fim, foram feitos gráficos com os resultados encontrados nas análises das variáveis dependentes no grupo que assistiu ao líder autêntico (Figura 5).

Figura 5 - Grau de Identificação \& Percepção de eficácia (Líder Autêntico)

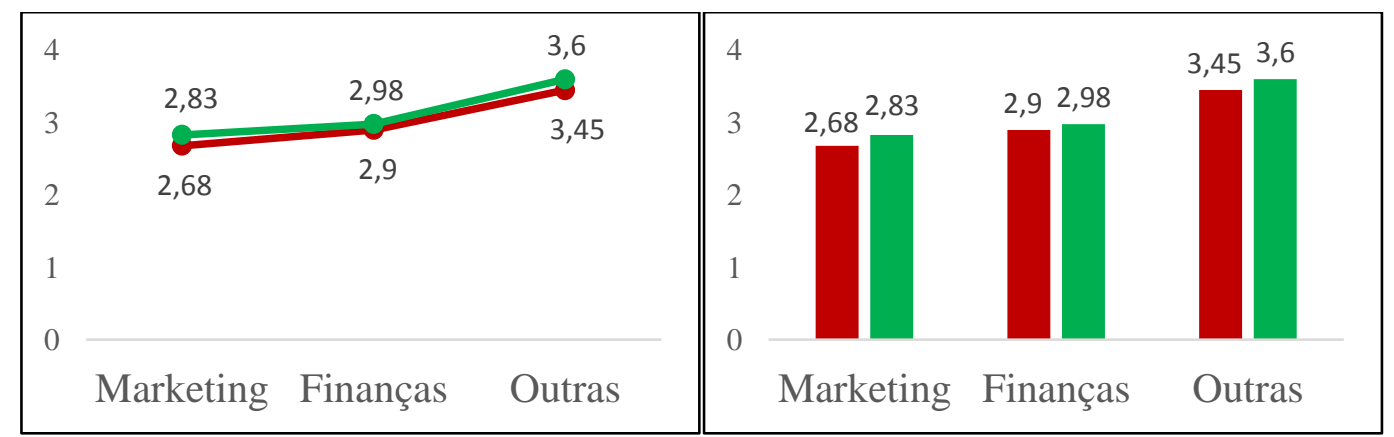

Grau de Identificação $\square$ Percepção de Desempenho 
Assim, é possível evidenciar a variação das médias das variáveis dependentes para cada uma das três áreas ocupacionais de análise. Nesse sentido, cabe ressaltar que apesar das médias do grau de identificação e percepção de eficácia serem muito semelhantes, somente houve indicação de diferenças significativas na variação de “Outras áreas” para Marketing e Finanças na variável percepção de eficácia.

Como forma de expandir os achados deste primeiro experimento, optou-se ainda por averiguar se os mesmos resultados ocorreriam para o grupo experimental 2 (líder inautêntico). Com isso, foi feito um filtro para os participantes, das três áreas, que viram o líder com baixo grau de autenticidade ( $\mathrm{N}$ =111). Foram feitas ANOVAS para as variáveis demográficas de controle: sexo $(\mathrm{F}=2,76 ; \mathrm{p}=0,068)$ idade $(\mathrm{F}=0,40 ; \mathrm{p}=0,670)$ e tempo de área $(\mathrm{F}=1,61 ; \mathrm{p}=$ 0,204). Como não foram encontradas diferenças sistemáticas entre as áreas que assistiram o líder inautêntico, os grupos foram considerados equivalentes.

Em seguida, são mostradas as estatísticas descritivas e coeficientes de correlações calculados para as variáveis da amostra de participantes do líder inautêntico (Tabela 10). A partir dos resultados é possível observar a forte correlação positiva entre tempo de área e idade $\left(\mathrm{R}=0,65^{* *}\right)$. Marketing apresentou correlação positiva com sexo $\left(\mathrm{R}=0,22^{*}\right)$ e negativa com Finanças ( $\mathrm{R}$ $\left.=-0,34^{* *}\right)$. Por sua vez, "Outras áreas" indicou somente correlações fortemente negativas com Finanças $\left(\mathrm{R}=-0,66^{* *}\right)$ e com Marketing $(\mathrm{R}=-0,49 * *)$. Quanto às variáveis de interesse, o grau de identificação apresentou correlação positiva com sexo $\left(\mathrm{R}=0,31^{* *}\right)$. Esta correlação do grau de identificação com o sexo poderia gerar problemas de efeitos na avaliação, contudo, como os grupos são equivalentes esse problema é mitigado. Por fim, a percepção de eficácia apresentou correlação negativa com idade $(\mathrm{R}=-0,21 *)$ e "Outras áreas" $(\mathrm{R}=$ $\left.0,22^{*}\right)$ e forte correlação positiva com o grau de identificação $\left(\mathrm{R}=0,79^{* *}\right)$. Da mesma forma, devido à equivalência dos grupos, a correlação entre percepção de eficácia e idade não apresenta maiores problemas para os resultados encontrados nas análises posteriores. 
Tabela 10 - Estatísticas Descritivas e Correlações para o grupo experimental 2 (Líder Inautêntico)

\begin{tabular}{|c|c|c|c|c|c|c|c|c|c|}
\hline Variáveis & Média & DP & 1 & 2 & 3 & 4 & 5 & 6 & 7 \\
\hline 1. Sexo $(1=F ; 2=M)$ & 1,51 & 0,50 & & & & & & & \\
\hline 2. Idade & 32,96 & 6,78 &,- 07 & & & & & & \\
\hline 3. Tempo de Área & 8,57 & 6,46 &, 11 &, $65 * *$ & & & & & \\
\hline 4. Finanças & 0,31 & 0,47 &,- 02 &,- 06 &,- 17 & & & & \\
\hline 5. Marketing & 0,20 & 0,40 &, $22 *$ &,- 04 &, 06 &,$- 34 * *$ & & & \\
\hline 6. Outras & 0,49 & 0,50 &,- 16 & ,09 &, 11 &,$- 66^{* *}$ &,$- 49 * *$ & & \\
\hline 7. Grau de Identificação & 1,66 & 0,88 &, $31^{* *}$ &,- 18 &,- 01 &, 09 &, 11 &,- 17 & \\
\hline 8. Percepção Eficácia & 2,05 & 0,99 &, 12 &,$- 21 *$ &,- 16 &, 19 & ,06 &,$- 22 *$ &, $79 * *$ \\
\hline
\end{tabular}

$\mathrm{N}=111 * . \mathrm{p}<0.05 * * . \mathrm{p}<0.01$

Fonte: Elaborado pelo autor 
A seguir, foi feita uma ANOVA para averiguar se há diferenças entre os profissionais que assistiram ao líder inautêntico (Tabela 11). A variável dependente é o grau de identificação. Ou seja, o intuito era, primeiramente, observar se há diferença no grau de identificação percebido pelos profissionais das três diferentes áreas. Depois, observar se profissionais da área de Marketing se identificam mais com o líder inautêntico do que profissionais de outras áreas, assim como entender se profissionais da área de Finanças se identificam mais com um líder inautêntico do que profissionais de outras áreas. Tendo isso em vista, os resultados da ANOVA evidenciaram que não há uma diferença entre os graus de identificação dos grupos analisados $(F=1,69 ; \mathrm{p}=0,189)$, conforme mais detalhadamente visualizado com o teste Post Hoc (Tukey HSD). Com isso, apesar da média absoluta de identificação das outras áreas ter sido menor do que a de Marketing e a de Finanças, não houve uma diferença significativa nesta percepção, sendo considerados como grupos estatisticamente iguais. Para melhor compreensão, estes resultados são apresentados abaixo:

Tabela 11 - ANOVA e Post Hoc para Identificação por Área (Líder Inautêntico)

\begin{tabular}{|c|c|c|c|c|c|c|}
\hline \multirow{2}{*}{\multicolumn{2}{|c|}{ Diferenças entre Grupos }} & \multicolumn{2}{|c|}{ ANOVA } & \multicolumn{3}{|c|}{ Comparação Múltipla (Tukey HSD) } \\
\hline & & $\mathrm{F}$ & Sigma & Diferença & $\mathrm{DP}$ & Sigma \\
\hline \multirow{2}{*}{ Outras } & Marketing & \multirow{6}{*}{1,69} & \multirow{6}{*}{0,189} & $-0,35$ & 0,22 & ,266 \\
\hline & Finanças & & & $-0,28$ & 0,19 &, 323 \\
\hline \multirow{2}{*}{ Marketing } & Outras & & & 0,35 & 0,22 & ,266 \\
\hline & Finanças & & & 0,07 & 0,24 & ,955 \\
\hline \multirow{2}{*}{ Finanças } & Outras & & & 0,28 & 0,19 &, 323 \\
\hline & Marketing & & & $-0,07$ & 0,24 & ,955 \\
\hline
\end{tabular}

Obs: Variável dependente - Grau de Identificação

*Diferença entre médias significativa para um nível de 0,05 .

Por fim, foi desenvolvida uma última ANOVA para averiguar se há diferenças entre os profissionais que assistiram ao líder inautêntico (Tabela 12). A variável dependente é a percepção de eficácia do líder. Ou seja, o intuito era, primeiramente, observar se há diferença na eficácia percebida do líder pelos profissionais das três diferentes áreas. Depois, observar se profissionais da área de Marketing veem um líder inautêntico como mais eficaz do que profissionais de outras áreas, assim como entender se profissionais da área de Finanças veem um líder inautêntico como mais eficaz do que profissionais de outras áreas. Tendo isso em vista, os resultados da ANOVA evidenciaram que, para um nível de 
significância de 0,05 , não há uma diferença entre a percepção de eficácia do líder nos grupos analisados $(F=2,83 ; p=0,063)$, conforme mais detalhadamente visualizado com o teste Post Hoc (Tukey HSD). Com isso, apesar da média absoluta de percepção de eficácia do líder das outras áreas ter sido menor do que a de Marketing e a de Finanças, não houve uma diferença significativa nesta percepção, sendo considerados como grupos estatisticamente iguais. Para melhor compreensão, estes resultados são apresentados abaixo:

Tabela 12 - ANOVA e teste Post Hoc para Eficácia por Área (Líder Inautêntico)

\begin{tabular}{|c|c|c|c|c|c|c|}
\hline \multirow{2}{*}{\multicolumn{2}{|c|}{ Diferenças entre Grupos }} & \multicolumn{2}{|c|}{ ANOVA } & \multicolumn{3}{|c|}{ Comparação Múltipla (Tukey HSD) } \\
\hline & & $\mathrm{F}$ & Sigma & Diferença & DP & Sigma \\
\hline \multirow{2}{*}{ Outras } & Marketing & \multirow{6}{*}{2,83} & \multirow{6}{*}{0,063} & $-0,33$ & 0,25 &, 374 \\
\hline & Finanças & & & $-0,49$ & 0,21 &, 060 \\
\hline \multirow{2}{*}{ Marketing } & Outras & & & 0,33 & 0,25 & ,374 \\
\hline & Finanças & & & $-0,16$ & 0,27 & ,818 \\
\hline \multirow{2}{*}{ Finanças } & Outras & & & 0,49 & 0,21 & ,060 \\
\hline & Marketing & & & 0,16 & 0,27 & ,374 \\
\hline
\end{tabular}

Obs: Variável dependente - Percepção de Eficácia

*Diferença entre médias significativa para um nível de 0,05 .

Por fim, foram feitos gráficos como forma de compilar as médias encontradas das duas variáveis dependentes por área ocupacional nas análises para o grupo experimental 2 (líder inautêntico) (Figura 6). Assim, apesar das diferenças absolutas entre as médias das áreas, não foram encontradas diferenças significativas. Contudo, vale ressaltar, a diferença de avaliação entre as variáveis dependentes. Ou seja, os profissionais de todas as áreas analisadas veem o líder inautêntico como mais eficaz do que se identificam com o mesmo. Isto pode ser detalhadamente observado a seguir:

Figura 6 - Grau de Identificação \& Percepção de Eficácia (Líder Inautêntico)

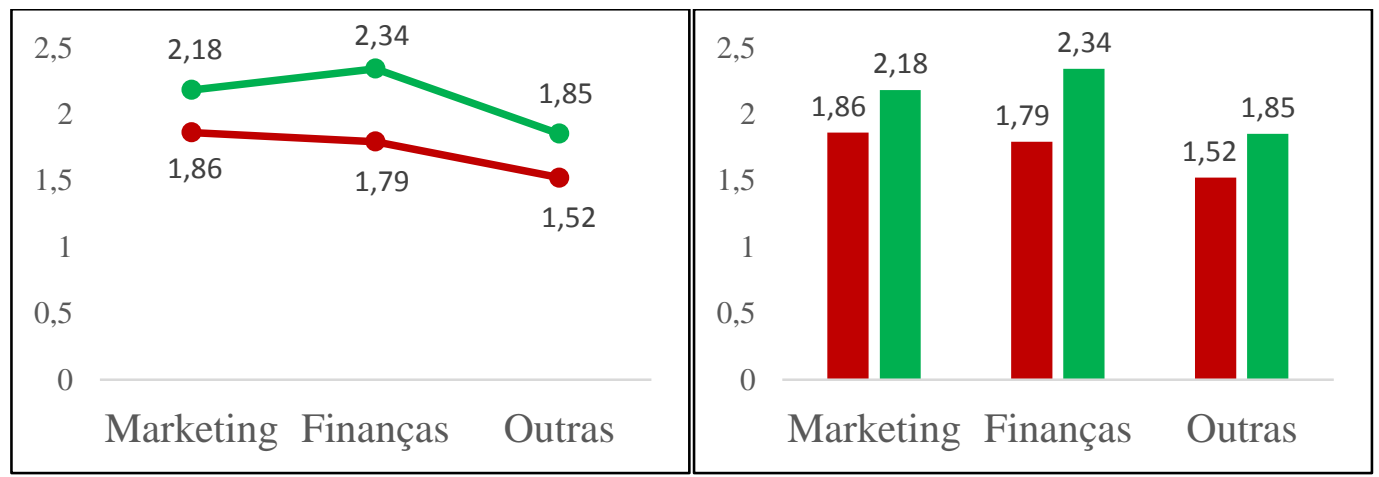

$\square$ Grau de Identificação $\quad \square$ Percepção de Desempenho 


\section{3.}

\section{Conclusões e Discussões - Experimento 1}

O experimento 1 evidenciou que o líder autêntico é percebido como mais efetivo, tanto no nível de identificação como nos julgamentos sobre a eficácia. Evidenciou-se, também, que a área ocupacional do seguidor modera o efeito da liderança autêntica sob as percepções de efetividade acerca do líder autêntico. Assim, com a confirmação das hipóteses H4, H5 e H6, foi visto que profissionais de Marketing e de Finanças veem um líder autêntico como menos efetivo do que profissionais de outras áreas. Da mesma forma, observou-se que profissionais de marketing e de finanças avaliam igualmente a efetividade de um líder autêntico. Em outras palavras, os achados equivalem a dizer que quando um líder apresenta, em seus valores declarados, autoconhecimento, perspectiva moral internalizada, balanceamento processado de informações e transparência relacional (WALUMBWA et al., 2008), os seguidores profissionais das áreas de marketing e de finanças tendem a vê-lo como menos efetivo do que profissionais de outras áreas e igualmente entre elas. Nesse sentido, estes resultados, de certa forma, se alinham com aqueles encontrados por O’Higgins e Kelleher (2005), contudo, sob um enfoque, no presente estudo, mais voltado para a percepção da liderança do que para o desenvolvimento moral dos profissionais. Observou-se, ainda, que no referente às análises do líder inautêntico, não houve nenhuma diferença significativa entre os grupos funcionais, tanto para a variável grau de identificação quanto para a percepção de eficácia do líder.

Além disso, foi visto por último, com a confirmação da hipótese H3, que profissionais de marketing e finanças possuem o mesmo grau de identificação para com o líder. Por outro lado, houve a rejeição das hipóteses H1 e H2. Ou seja, apesar das médias absolutas terem sido inferiores, não foram encontradas evidências de associações significativas no que diz respeito ao fato de tanto profissionais de marketing quanto de finanças se identificarem menos com um líder autêntico do que profissionais de outras áreas. Tendo isso em vista, esses achados podem ter sido ocasionados por alguns motivos.

Primeiro, pode-se refletir se o fato de ter tratado todas as outras áreas funcionais como um único grupo acabou interferindo de alguma forma no resultado. Como o grupo "outras áreas” pode ser muito heterogêneo, a atribuição 
de uma "percepção grupal" poderia ocasionar falhas. Talvez, se houvesse uma comparação de culturas ocupacionais mais distantes, como se suporia entre somente profissionais de $\mathrm{RH}$ com Marketing ou somente $\mathrm{RH}$ com finanças, os resultados poderiam ter sido diferentes. Contudo, devido à baixa taxa de resposta de profissionais de $\mathrm{RH}$, este estudo encontrou tais limitações, impossibilitando esta análise. Nesse sentido, os resultados poderiam ainda ter sido ocasionados por uma peculiaridade da amostra. Como os participantes do experimento realizam pós graduação e, em alguns casos, acabam convivendo com profissionais de outras áreas, a tendência de se homogeneizar os resultados se amplia. Contudo, cabe ressaltar que, mesmo as diferenças na identificação não terem sido estatisticamente significativas, eles indicam levemente a preferência dos profissionais de outras áreas para com um líder autêntico, quando comparados a profissionais de marketing e de finanças.

Por sua vez, caso os resultados expressem, de fato, a realidade, é possível propor diversas recomendações e implicações práticas. Nesse sentido, cabe esclarecer que, pela visualização das médias, entre os líderes com diferentes graus de autenticidade, todos os profissionais tiveram maior preferência pelo autêntico, seja no referente a percepção de eficácia, como também na identificação. Esse achado revela a importância da busca pelo desenvolvimento de líderes mais autoconscientes, transparentes, desenvolvidos moralmente e com processamento de informações mais equilibrado no ambiente empresarial.

Além disso, os resultados evidenciam o efeito moderador da área ocupacional na percepção de eficácia do líder, mostrando que estar numa determinada área pode impactar na maneira como o líder é enxergado. Assim, ao lidar com profissionais de outras áreas (Recursos Humanos, Tecnologia da Informação, Pesquisa \& Desenvolvimento, Logística, Gestão de Projetos etc.), um líder autêntico terá ainda mais efetividade, obtendo mais avaliações positivas. Da mesma, um líder inautêntico ao lidar com esses profissionais, será visto de forma mais rigorosa, obtendo uma âncora negativa em suas avaliações de efetividade.

Por último, conclui-se que, pelo menos no que diz respeito à avaliação de eficácia de um líder autêntico, profissionais de marketing e de finanças são diferenciados dos outros e assim devem ser tratados. Ambos são menos sensíveis em suas percepções a variações na autenticidade do líder e isto pode ser devido às características intrínsecas de suas funções, conforme já apontado por Ferrel et al. 
(2000) e O'Higgins e Kelleher (2005). Por se tratarem de funções mais monetariamente envolvidas, com menores graus médios de desenvolvimento moral, com maiores pressões e menores contatos pessoais, os profissionais dessas áreas tendem a enxergar com menor sensibilidade os líderes. Portanto, apesar terem apresentados médias superiores nas avaliações para o líder autêntico, a preocupação com o desenvolvimento de líderes para atuar nestas áreas já não se mostra tão relevante. Em outras palavras, as implicações práticas destes resultados sugerem que um líder autêntico não seria mais eficaz nestas áreas e que, portanto, não caberia investir no desenvolvimento da autenticidade dos líderes que estão imersos nestas culturas ocupacionais.

No concernente a limitações específicas no decorrer da pesquisa, observouse que, inicialmente, houve uma taxa de resposta menor do que a esperada, seja devido à baixa frequência de alunos nas sessões, como também à grande heterogeneidade de casos que impossibilitam o enquadramento de um indivíduo em uma determinada condição. Por exemplo, alguns indivíduos possuem mais de uma formação e/ou função laboral exercida, como também, em alguns casos, uma mistura das atividades dentro das três áreas ocupacionais foco da pesquisa (Ex: Corretor da bolsa de valores com MBA em Recursos Humanos). Nesse sentido, como forma de mitigar um pouco essa baixa taxa de resposta, conseguiu-se realizar o experimento em novas sessões que não foram anteriormente planejadas, chegando-se a um número maior de respondentes. Por outro lado, ainda sim houve uma limitação de tempo e recursos que impossibilitaram o alcance integral do que foi planejado durante o desenho do projeto.

Para pesquisas futuras, são sugeridos estudos que investiguem mais os potenciais efeitos de personalidade (nível individual) e de cultura (nível organizacional), intrínsecos a cada uma das áreas funcionais, na liderança. Além disso, caberia, reproduzir modelos semelhantes ao empregado nesta pesquisa em outros contextos, como forma de verificar a permanência dos achados e assegurar a generalização dos impactos causados pelas variáveis. Por fim, sugere-se, ainda, uma interação maior da cultura ocupacional com outros construtos, tais como: criatividade, empowerment, capital intelectual, etc. Nesse sentido, caberia, até mesmo, avaliar o efeito das emoções do líder por área ocupacional, buscando captar preferências específicas de cada área funcional por um líder com emoções mais positivas, neutras ou negativas. 


\section{4}

\section{Experimento 2}

\section{1. Método do Estudo}

\subsection{1.}

\section{Procedimento}

Este experimento visou compreender o efeito da expressão de emoções positivas e negativas na percepção de eficácia e no grau de identificação de seguidores com um líder. Assim, este segundo experimento buscou testar se líderes autênticos que expressam emoções positivas (alegria/ânimo) são percebidos como mais efetivos por seguidores do que líderes emocionalmente neutros ou que expressam emoções negativas (tristeza/desânimo). Ou seja, neste estudo, as emoções do líder foram objeto de manipulação.

Para este segundo experimento, foi utilizado o vídeo do líder autêntico do estudo anterior (apresentação da empresa, discurso autentico, sem expressão de emoções) como grupo de controle. Foram gravados outros dois vídeos em que o ator profissional repetiu o mesmo texto (apresentação da empresa e discurso autêntico), porém expressando emoções positivas (experimental 1) e outro em que o ator proferiu mais uma vez o mesmo texto, porém expressando emoções negativas (experimental 2) (ver Apêndice 3). Ou seja, os vídeos eram idênticos, apresentando exatamente o mesmo discurso e no mesmo cenário (suíte executiva), alterando somente as emoções expressadas pelo líder. O vídeo de controle durou 1:45 enquanto que os experimentais 1 (emoções positivas) e 2 (emoções negativas), duraram, respectivamente, 1:48 e 1:54 minutos.

\subsection{2.}

\section{Amostra}

A amostra da pesquisa é composta por 172 estudantes de graduação em administração de uma universidade localizada no Rio de Janeiro. Destes 172 respondentes, 89 eram homens $(51,74 \%)$ e 83 mulheres $(48,26 \%)$. A idade média foi de 21,12 anos (DP = 2,76), sendo que 34,3\% trabalham ou já trabalharam. Ademais, o coeficiente de rendimento (CR) médio desses estudantes é de 7,33 $(\mathrm{DP}=0,90)$. Os 172 participantes foram divididos de forma randômica em três 
grupos, onde assistiram a um dos três diferentes vídeos. O número de respondentes para os vídeos do líder de emoções positivas, neutras e negativas foi, respectivamente, de 55, 55 e 62 . Estas classificações e dados amostrais por grupos podem ser visualizadas detalhadamente na tabela 13 , abaixo:

Tabela 13 - Dados Amostrais dos Participantes por vídeo assistido

\begin{tabular}{|c|c|c|c|c|}
\hline Variáveis & Emoção Positiva & Emoção Neutra & Emoção Negativa & Total \\
\hline Sexo & $41,8 \% \mathrm{~F} \quad 58,2 \% \mathrm{M}$ & $56,4 \% \mathrm{~F} \quad 43,6 \% \mathrm{M}$ & $46,8 \% \mathrm{~F} \quad 53,2 \% \mathrm{M}$ & $48,3 \% \mathrm{~F} \quad 51,7 \% \mathrm{M}$ \\
\hline Idade & $\bar{x}=20,84 ; \mathrm{DP}=2,30$ & $\bar{x}=22,04 ; \mathrm{DP}=3,32$ & $\bar{x}=20,56 ; \mathrm{DP}=2,42$ & $\bar{x}=21,12 ; \mathrm{DP}=2,76$ \\
\hline $\mathrm{CR}$ & $\bar{x}=7,51 ; \mathrm{DP}=0,88$ & $\bar{x}=7,3 ; \mathrm{DP}=0,70$ & $\bar{x}=7,24 ; \mathrm{DP}=1,08$ & $\bar{x}=7,33 ; \mathrm{DP}=0,90$ \\
\hline Trabalha & $41,8 \% \mathrm{~S} \quad 58,2 \% \mathrm{~N}$ & $65,5 \% \mathrm{~N}$ & $72,6 \% \mathrm{~N}$ & $34,3 \% \mathrm{~S}$ \\
\hline Participantes & 55 Estudantes & 55 Estudantes & 62 Estudantes & 172 Estudantes \\
\hline
\end{tabular}

Fonte: Elaborado pelo autor

\subsection{3.}

\section{Coleta de Dados}

$\mathrm{Na}$ segunda etapa do experimento, desenvolveu-se um novo questionário (ver Apêndice 4). No questionário para esse segundo experimento foram mais enfatizadas questões relacionadas a percepção da emocionalidade tanto do líder quanto a do respondente. Em resumo, a primeira parte dele era de avaliação do grau de identificação para com o líder, percepção de eficácia e percepção do nível de autenticidade do líder. A segunda parte era composta de escalas de avaliação das emoções expressadas pelo líder, para observar a eficácia da manipulação, e do seu próprio grau de afetividade. Por fim, a última etapa era o preenchimento de algumas questões demográficas (ver item 4.1.4. Escalas de Mensuração).

A condução do experimento, que ocorreu na PUC-Rio, foi feita em 12 sessões, onde em quatro delas foi passado o vídeo de controle, quatro o vídeo experimental 1 (emoções positivas) e quatro o vídeo experimental 2 (emoções negativas). No momento de coleta dos dados, foi solicitado aos respondentes que não conversassem com colegas e que mesmo depois da apresentação, evitassem comentar com pessoas até o término total da coleta de dados do estudo, com o intuito de evitar contaminações. Também foi informado o tempo de duração médio total esperado do experimento (15 minutos). Antes do vídeo, foi solicitado, ainda, que todos prestassem bastante atenção, pois seria um vídeo de boas-vindas, gravado pelo CEO de uma grande empresa que iria se apresentar e falar sobre os 
valores da empresa para a entrada de novos funcionários. Além disso, o método de escolha do vídeo que iria ser passado em cada sessão era feito com base em uma contagem preliminar do número de participantes. Ou seja, a condição que houvesse menor número de participantes até o determinado momento do experimento em uma nova sessão era a que seria utilizada.

\subsection{4.}

\section{Escalas de Mensuração}

Percepção de Eficácia - Foram elaborados três itens que visam avaliar a percepção do seguidor para com a eficácia do líder. Os itens que compõem está escala são: "Esse CEO é um bom líder", "Eu me dedicaria mais e aumentaria minha produtividade com um líder como esse" e "Eu acredito que esse líder teria um alto desempenho na área em que trabalho". Participantes avaliam suas percepções de eficácia por meio de uma escala Likert ( 1 = Discordo Totalmente, 5 = Concordo Totalmente). O Alpha de Cronbach da escala calculado para a amostra deste estudo foi de 0,857 .

Identificação com o Líder - Foram elaborados outros três itens que buscam identificar o grau de identificação do seguidor para com o líder. Assim sendo, os itens que compõem a escala são: "Esse CEO corresponde à imagem que eu tenho de um líder", "Eu me identifico com esse líder" e "Eu gostaria de ter esse CEO como líder formal (chefe)". Respondentes atribuem seu grau de identificação com o líder por intermédio de uma escala Likert $(1$ = Discordo Totalmente, $5=$ Concordo Totalmente). O Alpha de Cronbach da escala calculado para a amostra deste estudo foi de 0,903 .

Liderança Autêntica - Adotou-se a escala desenvolvida por Walumbwa et al. (2008) (Questionário de Liderança Autêntica (ALQ). Distribuído por Mind Garden, Inc. www.mindgarden.com). Essa métrica busca avaliar o grau de autenticidade do líder que é percebido pelos seguidores, sendo composta de 16 itens que refletem as quatro dimensões propostas pela teoria. Alguns exemplos de itens são: "O líder diz exatamente o que pensa" e "O líder admite quando comete erros". Participantes avaliam a frequência de determinados comportamentos do líder por meio de uma escala de cinco pontos $(1=$ nunca, $5=$ frequentemente, se 
não sempre). O Alfa de Cronbach original da escala é 0,84 e o calculado para a amostra deste estudo foi de 0,910 .

Estados Afetivos Transitórios - Optou-se pela utilização da escala de 15 itens desenvolvida por McNair et al. (1971). Essa métrica foi usada com o intuito de se avaliar, pelos seguidores, o perfil de estado de humor e emocional do líder. Ela contém itens como "O líder está feliz" e "O líder está desanimado". Participantes avaliam o estado afetivo do líder com base em uma escala de sete pontos ( $1=$ Totalmente Incorreto, $7=$ Totalmente Correto). O Alpha de Cronbach da escala calculado para a amostra deste estudo foi de 0,918 .

Intensidade Emocional - Esta escala desenvolvida por Goldberg et al. (2006), apresenta 10 itens, tendo como exemplos: "Eu vivencio minhas emoções intensamente" e "Eu não compreendo pessoas que ficam emocionadas" Participantes avaliam sua própria intensidade afetiva por intermédio de uma escala de cinco pontos $(1=$ Muito Inapropriada, $5=$ Muito Apropriada). O Alpha de Cronbach da escala calculado para a amostra deste estudo foi de 0,697.

Dados Demográficos - Foram solicitados aos participantes que respondessem questões referentes a gênero, idade, coeficiente de rendimento (CR), se trabalha ou não e tempo de experiência. Estas perguntas foram utilizadas como controle para o experimento, como forma de garantir a homogeneidade dos grupos analisados.

\section{2.}

\section{Análise de Resultados - Experimento 2}

Inicialmente, como forma de validar os resultados que serão expostos ao longo dessa seção, buscou-se checar a manipulação experimental da variável da afetividade positiva e negativa do líder. Assim, foi feito um teste de análise da variância e, posteriormente, um teste Post Hoc (tabela 14) com o objetivo de observar as diferenças entre os grupos. Os resultados da ANOVA indicaram, primeiramente, que houve uma diferença significativa entre as médias dos grupos analisados $(F=99,55 ; p<0,001)$. Dessa forma, como segunda etapa do exame, realizou-se um teste Post Hoc (Tukey HSD) visando proceder comparações múltiplas entre os grupos. O resultado dessa analise indicou que houve diferenças 
significativas na percepção das emoções do líder entre os três grupos, de acordo com o objetivo da manipulação (ver diferenças na tabela 5). Ou seja, no grupo experimental 1, os participantes julgaram a afetividade do líder como significativamente mais positiva $(\overline{\mathrm{x}}=5,52 ; \mathrm{DP}=0,88)$, seguido pelo grupo de controle com afetividade neutra $(\overline{\mathrm{x}}=4,84$; DP $=0,93)$ e, por fim, o grupo experimental 2, apresentando médias significativamente mais baixas $(\overline{\mathrm{x}}=$ $3,34 ; \quad \mathrm{DP}=0,77)$.

Tabela 14 - ANOVA e teste Post Hoc para teste do efeito da manipulação

\begin{tabular}{|c|c|c|c|c|c|c|}
\hline \multirow{2}{*}{\multicolumn{2}{|c|}{ Diferenças entre Grupos }} & \multicolumn{2}{|c|}{ ANOVA } & \multicolumn{3}{|c|}{ Comparação Múltipla (Tukey HSD) } \\
\hline & & $\mathrm{F}$ & Sigma & Diferença & DP & Sigma \\
\hline \multirow{2}{*}{ Neutro } & Positiva & \multirow{6}{*}{99,55} & \multirow{6}{*}{0,000} & $-0,68 *$ & 0,16 &, 000 \\
\hline & Negativa & & & $1,50 *$ & 0,16 & ,000 \\
\hline \multirow{2}{*}{ Positiva } & Neutro & & & $0,68 *$ & 0,16 & , 000 \\
\hline & Negativa & & & $2,18 *$ & 0,16 & , 000 \\
\hline \multirow{2}{*}{ Negativa } & Neutro & & & $-1,50 *$ & 0,16 & 000 \\
\hline & Positiva & & & $-2,18^{*}$ & 0,16 & ,000 \\
\hline
\end{tabular}

Obs: Variável dependente - Emocionalidade do Líder

*Diferença entre médias significativa para um nível de 0,05 .

Após esta etapa, as estatísticas descritivas e coeficientes de correlações foram calculados (tabela 15). Para esta análise, foram criadas duas variáveis dummies, sendo uma delas referente ao grupo experimental 1 (líder com afetividade positiva) e a outra referente ao grupo experimental 2 (líder com afetividade negativa). A partir da visualização destes resultados é possível observar, inicialmente, que estas duas dummies apresentaram correlação negativa entre elas $(\mathrm{R}=-0,52 * *)$. Outro indicativo de correlação ocorre entre emocionalidade do seguidor e sexo $\left(\mathrm{R}=-0,31^{* *}\right)$, indicando que mulheres nessa amostra apresentaram maior emocionalidade do que homens. A autenticidade do líder correlaciona tanto com a dummy líder positivo $(\mathrm{R}=0,29 * *)$ quanto com a dummy líder negativo $\left(\mathrm{R}=-0,44^{* *}\right)$. Por fim, no concernente às variáveis de maior interesse do estudo, identificou-se que o grau de identificação do seguidor para com o líder está positivamente correlacionado com a autenticidade $(\mathrm{R}=$ $0,70 * *)$ e foi maior no grupo experimental 1 (líder positivo) ( $\mathrm{R}=0,28 * *)$, e menor no grupo experimental 2 (líder negativo) $(\mathrm{R}=-0,52 * *)$. Da mesma forma, a percepção de desempenho apresentou fortemente correlacionada com a identificação $\left(\mathrm{R}=0,85^{* *}\right)$, com a autenticidade do líder $\left(\mathrm{R}=0,70^{* *}\right)$ e foi maior 
no grupo experimental 1 (líder positivo) $\left(\mathrm{R}=0,26^{* *}\right)$. Por outro lado foi menor no grupo experimental 2 (líder negativo) $\left(\mathrm{R}=-0,45^{* *}\right)$. Estas informações são detalhadamente compiladas a seguir:

Tabela 15 - Estatísticas Descritivas e Coeficientes de Correlação

\begin{tabular}{l|cccccccc}
\hline Variáveis & Média & DP & $\mathbf{1}$ & $\mathbf{2}$ & $\mathbf{3}$ & $\mathbf{4}$ & $\mathbf{5}$ & $\mathbf{6}$ \\
\hline 1. Sexo $(1=\mathrm{F} ; 2=\mathrm{M})$ & 1,52 & 0,50 & & & & & & \\
2. Líder Positivo & 0,32 & 0,47 &, 09 & & & & \\
3. Líder Negativo & 0,36 & 0,48 &, 02 &,$- 52^{* *}$ & & & & \\
4. Emocionalidade Seguid. & 3,92 & 0,49 &,$- 31^{* *}$ &, 01 &,- 03 & & \\
5. Autenticidade do Líder & 3,26 & 0,72 &, 01 &, $29 * *$ &,$- 44 * *$ &,- 05 & & \\
6. Grau de Identificação & 2,75 & 1,21 &,- 12 &, $28 * *$ &,$- 52^{* *}$ &, 00 &, $70^{* *}$ & \\
7. Percepção Eficácia & 2,94 & 1,02 &,- 10 &, $26 * *$ &,$- 45^{* *}$ &,- 05 &, $70^{* *}$ &, $85^{* *}$ \\
\hline \multicolumn{1}{c}{$\mathrm{N}=172 * . \mathrm{p}<0.05$} & $* *$ & $\mathrm{p}<0.01$
\end{tabular}

$\mathrm{Na}$ terceira etapa da análise, elaborou-se outra ANOVA, objetivando-se testar as três primeiras hipóteses relativas a este segundo experimento (tabela 16). A variável dependente era a percepção de desempenho dos líderes. Ou seja, o intuito era, primeiramente, observar se há diferença na percepção de efetividade dos três diferentes líderes. Depois, identificar se o líder com emoções positivas foi percebido como mais efetivo do que o líder de emoções neutras (H7) e emoções negativas (H8), assim como verificar se o líder de emoções neutras foi percebido como mais efetivo do que o líder negativo na visão dos seguidores (H9). Os resultados da ANOVA evidenciaram que houve uma diferença significativa entre as percepções de desempenho dos grupos analisados $(F=21,83 ; p<0,001)$. Em seguida, o teste Post Hoc revelou que, apesar de ter obtido uma média superior $(\bar{x}=3,37)$, o líder positivo não obteve uma diferença significativa quando comparado com o líder de emocionalidade neutra $(0,09)$. Por outro lado, ambos apresentaram diferenças significativas $(1,00 *$ e $0,92 *)$ ao serem comparadas com o líder de emocionalidade negativa. Portanto, depreende-se que a hipótese $\mathrm{H} 7$ foi rejeitada, enquanto que as hipóteses $\mathrm{H} 8$ e $\mathrm{H} 9$ foram, de fato, confirmadas e validadas pelos resultados. Estes são apresentados na tabela abaixo: 
Tabela 16 - ANOVA e Post Hoc para hipóteses de Eficácia

\begin{tabular}{|c|c|c|c|c|c|c|}
\hline \multirow{2}{*}{\multicolumn{2}{|c|}{ Diferenças entre Grupos }} & \multicolumn{2}{|c|}{ ANOVA } & \multicolumn{3}{|c|}{ Comparação Múltipla (Tukey HSD) } \\
\hline & & $F$ & $\begin{array}{l}\text { Sigma } \\
\text { Siga }\end{array}$ & Diferença & DP & Sigma \\
\hline \multirow{2}{*}{ Neutro } & Positiva & \multirow{6}{*}{21,83} & \multirow{6}{*}{0,000} & $-0,09$ & 0,18 &, 862 \\
\hline & Negativa & & & $0,92^{*}$ & 0,17 & ,000 \\
\hline \multirow{2}{*}{ Positiva } & Neutro & & & 0,09 & 0,18 & ,862 \\
\hline & Negativa & & & $1,00^{*}$ & 0,17 & ,000 \\
\hline \multirow{2}{*}{ Negativa } & Neutro & & & $-0,92 *$ & 0,17 & ,000 \\
\hline & Positiva & & & $-1,00 *$ & 0,17 & .000 \\
\hline
\end{tabular}

Variável dependente: Percepção de Eficácia do Líder

*Diferença entre médias significativa para um nível de 0,05 .

Subsequentemente, foi realizada uma regressão múltipla com o intuito de avaliar melhor o efeito direto de certas variáveis nesta valoração do desempenho (tabela 17). Foram elaborados três modelos. O primeiro com duas variáveis de controle, o segundo com a inclusão do efeito da líder positivo e o terceiro modelo com o efeito do líder negativo. No modelo 1, nenhuma das duas variáveis teve associação significativa com a percepção de desempenho. No modelo 2 , o efeito do líder positivo mostrou-se positivamente associado ao desempenho do líder ( $\beta=$ $0,61$ e t $=3,78, p<0,001)$. No entanto, no modelo 3, somente o efeito do líder negativo se apresentou como fortemente associado à percepção de desempenho ( $\beta$ $=-0,90$ e $\mathrm{t}=-5,28, \mathrm{p}<0,001)$, porém de forma negativa. Além disso, neste terceiro modelo, o coeficiente de determinação foi significativo $\left(\mathrm{R}^{2}=0,23, \mathrm{~F}=\right.$ 12,12). Tais informações podem ser visualizadas abaixo:

Tabela 17 - Regressão para Percepção de Eficácia do Líder

\begin{tabular}{|c|c|c|c|c|c|c|}
\hline \multirow[b]{2}{*}{ Variáveis } & \multicolumn{2}{|c|}{$\begin{array}{l}\text { Modelo } 1 \\
\text { Controle }\end{array}$} & \multicolumn{2}{|c|}{$\begin{array}{c}\text { Modelo } 2 \\
\text { Líder Positivo }\end{array}$} & \multicolumn{2}{|c|}{$\begin{array}{c}\text { Modelo } 3 \\
\text { Líder Negativo }\end{array}$} \\
\hline & $\boldsymbol{\beta}$ & $\mathbf{T}$ & $\beta$ & $\mathbf{t}$ & $\boldsymbol{\beta}$ & $\mathbf{T}$ \\
\hline 1 Sexo &,- 27 & $-1,66$ &,$- 33 *$ & $-2,08$ &,- 27 & $-1,8$ \\
\hline 2 Emocionalidade Seguidor &,- 19 & $-1,15$ &,- 22 & $-1,35$ &,- 22 & $-1,46$ \\
\hline 3 Líder Positivo & & &, $61 * * *$ & 3,78 & 13 & 0,74 \\
\hline 4 Líder Negativo & & & & &,$- 90 * * *$ & $-5,28$ \\
\hline $\mathrm{R}^{2}$ & \multicolumn{2}{|c|}{,02 } & \multicolumn{2}{|c|}{10} & \multicolumn{2}{|c|}{,23 } \\
\hline $\mathrm{R}^{2}$ Ajustado & \multicolumn{2}{|c|}{01} & \multicolumn{2}{|c|}{08} & \multicolumn{2}{|c|}{,21 } \\
\hline $\mathrm{F}$ & \multirow{2}{*}{\multicolumn{2}{|c|}{1,60}} & & & \multicolumn{2}{|c|}{12,12} \\
\hline$\Delta \mathrm{F}$ & & & \multicolumn{2}{|c|}{4,31} & \multicolumn{2}{|c|}{6,21} \\
\hline
\end{tabular}


Esses resultados da regressão corroboram e fazem referência àqueles discutidos na etapa anterior, demonstrando que a emoção imposta pelo líder no discurso possui um efeito na sua percepção de desempenho. Ou seja, vislumbra-se que a emocionalidade positiva teve um pouco de efeito positivo na forma como o líder é percebido, mas, principalmente, que a emocionalidade negativa possui um grande efeito negativo nesta maneira como o líder é visto. Tanto que a positividade do líder foi neutralizada no modelo 3, não apresentando, assim, uma associação positiva significativa $(\beta=0,13 \mathrm{e} \mathrm{t}=0,64 ; \mathrm{p}>0,05)$.

A última etapa de resultados buscou testar as últimas três hipóteses, relativas ao grau de identificação do seguidor com o líder (tabela 18). Ou seja, o intuito era, primeiramente, observar se há diferença no grau de identificação com os três diferentes líderes. Depois, identificar se o líder com emoções positivas proporcionaria maior identificação do que o líder com emoções neutras (H10) e emoções negativas (H11), assim como descobrir se o líder de emoções neutras acarretaria em maior identificação do que o líder negativo na visão dos seguidores (H12). Tendo isso em vista, os resultados da ANOVA evidenciaram, inicialmente, que há, de fato, uma diferença entre os graus de identificação dos grupos analisados $(\mathrm{F}=32,00 ; \mathrm{p}<0,001)$. Em seguida, o teste Post Hoc revelou que, apesar de ter obtido uma média superior $(\overline{\mathrm{x}}=3,24)$, o líder positivo não obteve uma diferença significativa quando comparado com o líder de emocionalidade neutra $(0,02)$. Por outro lado, ambos apresentaram diferenças significativas $\left(1,33^{*}\right.$ e 1,31*) ao serem comparadas com o líder de emocionalidade negativa. Portanto, depreende-se que a hipótese H10 foi rejeitada, enquanto que as hipóteses H11 e H12 foram, de fato, confirmadas e validadas pelos resultados. Estes são apresentados na tabela abaixo:

Tabela 18 - ANOVA e Teste Post Hoc para Hipóteses de Identificação

\begin{tabular}{|c|c|c|c|c|c|c|}
\hline \multirow{2}{*}{\multicolumn{2}{|c|}{ Diferenças entre Grupos }} & \multicolumn{2}{|c|}{ ANOVA } & \multicolumn{3}{|c|}{ Comparação Múltipla (Tukey HSD) } \\
\hline & & $\mathrm{F}$ & Sigma & Diferença & DP & $\begin{array}{l}\text { Sigma } \\
\text { aig }\end{array}$ \\
\hline \multirow{2}{*}{ Neutro } & Positiva & \multirow{6}{*}{32,00} & \multirow{6}{*}{0,000} & $-0,02$ & 0,20 & ,992 \\
\hline & Negativa & & & $1,31^{*}$ & 0,19 &, 000 \\
\hline \multirow{2}{*}{ Positiva } & Neutro & & & 0,02 & 0,20 & ,992 \\
\hline & Negativa & & & $1,33^{*}$ & 0,19 & ,000 \\
\hline \multirow{2}{*}{ Negativa } & Neutro & & & $-1,31 *$ & 0,19 & 000 \\
\hline & Positiva & & & $-1,33^{*}$ & 0,19 & ,000 \\
\hline
\end{tabular}

Obs: Variável dependente - Grau de Identificação com o Líder

*Diferença entre médias significativa para um nível de 0,05 . 
Para finalizar esta fase de análise de resultados, buscou-se desenvolver gráficos visuais para ilustrar, inclusive, a comparação entre o grau de identificação e percepção de desempenho para cada um dos líderes testados (figura 7). Assim foram elaborados dois gráficos: de linhas e de barras. Nesse sentido, vale ressaltar que as médias destas duas variáveis foram bem semelhantes para cada um dos três líderes, o que, inclusive, remonta à alta correlação observada entre elas. No entanto, a condição em que estas duas variáveis mais se dispersaram foi a do líder emocionalmente negativo, indicando, assim, que, em média, as pessoas percebiam mais efetividade com o líder negativo $(\overline{\mathrm{x}}=2,31, \mathrm{DP}=0,12)$ do que se identificam com ele $(\bar{x}=1,88, D P=0,13)$. Esta ilustração detalhada segue abaixo:

Figura 7 - Grau de Identificação \& Percepção de Eficácia

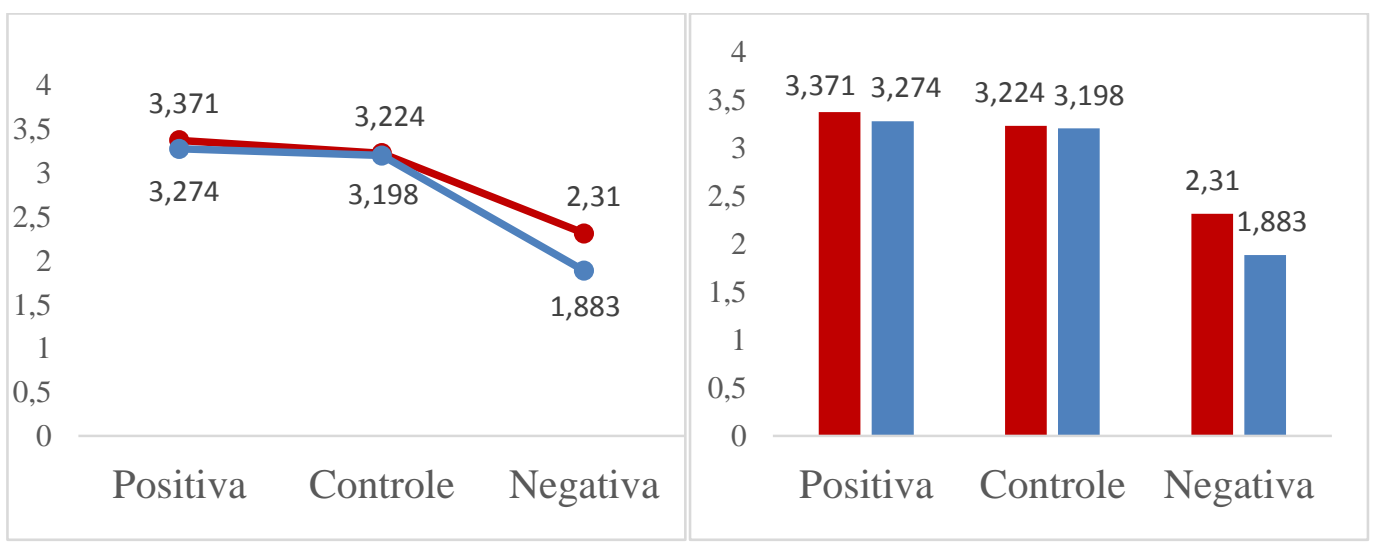

$\square$ Grau de Identificação

$\square$ Percepção de Eficácia

\section{3.}

Conclusões e Discussões - Experimento 2

Primeiramente, o experimento 2 desenvolveu evidências de que o estado emocional negativo de um líder autêntico tem efeito sobre a efetividade do líder, tanto no referente ao grau de identificação quanto à sua percepção de eficácia pelos seguidores. Assim, com a confirmação das hipóteses H8, H9, H11 e H12, foi visto que emoções positivas ou, no mínimo neutras, proporcionam uma melhor valoração do líder quando comparadas com líderes que possuem um estado emocional negativo. Em outras palavras, os achados equivalem a dizer que quando um líder expressa alegria e ânimo ou, até mesmo, a ausências desses estados afetivos, os seguidores se identificam mais e percebem, tanto o líder como 
eles próprios, como mais eficazes do que quando na presença de um líder triste e desanimado. Nesse sentido, este estudo se alinhou com aqueles realizados por Lewis (2000), McColl-Kennedy e Anderson (2002) e Gaddis et al. (2004), encontrando resultados esperados, principalmente no que diz respeito a este forte efeito negativo da expressão de emoções negativas na liderança, apesar de que, no presente estudo, estes elementos foram analisados para o estilo de líderes autênticos.

Por outro lado, com a rejeição das hipóteses H7 e H10, esta pesquisa apresentou resultados discrepantes com aqueles encontrados por Bono e Ilies (2006), e aí talvez resida a principal discussão a ser desenvolvida neste estudo e futuramente. Não foram encontradas evidências de associações significativas entre uma maior identificação e uma maior eficácia de um líder com estado emocional positivo quando comparados com um líder que apresente emocionalidade neutra. Nesse sentido, esse achado pode ter sido ocasionado por diversos fatores.

Primeiro, seria possível atribuir esse efeito a uma certa peculiaridade da amostra. Por ela ter sido composta por somente estudantes de graduação e, portanto, indivíduos com, de forma geral, pouca experiência de mercado, o líder positivo talvez não tenha apresentado um apelo tão alto quanto talvez seria evidenciado em uma amostra de executivos mais experientes. Por outro lado, não foi encontrado nada na literatura que sugira alguma divergência marcante na forma de valorar líderes entre esses dois grupos. Outra potencial causa para este efeito pode ser da escala de percepção de eficácia e do grau de identificação utilizada. Como ambas estavam misturadas e possuíam apenas três itens, talvez possa ter sido insuficiente para captar nuances nessas duas atribuições, tendo talvez, assim, a tendência de se avalia percepção de eficácia e grau de identificação de forma muito semelhante. Por outro lado, ambas as métricas foram testadas e seus Alphas de Cronbach são superiores a 0.80, o que remete a validade de sua aplicação.

Por sua vez, caso os resultados encontrados estejam, de fato, alinhados com a realidade, o presente estudo levanta uma profunda discussão. Em tempos atuais, onde toda a teoria de liderança autêntica está sendo questionada, devido a possibilidade de falhas durante seu desenvolvimento, os resultados desta pesquisa só corroboram para essa atenta revisão. A teoria da liderança autêntica pressupõe um grande efeito e importância na utilização de emoções positivas pelo líder 
(AVOLIO et al., 2004; MICHIE; GOOTY, 2005). Inclusive, esta teoria deveria focar, ainda mais, em elementos emocionais e afetivos do que em elementos cognitivos, como daquelas teorias desenvolvidas anteriormente (LORD; BROWN, 2004). Contudo, não foi observado isto neste trabalho. Os resultados indicaram a não relevância da utilização de emoções positivas quando comparadas a ausência de emoções. Assim, faz-se necessário discutir esses potenciais elementos influenciadores, replicar em outros contextos e, caso se aplique, rever toda a formulação de premissas e pressuposições sobre esta teoria, pelo menos no que diz respeito à importância da positividade do líder.

Tendo em vista estas implicações teóricas supramencionadas, este experimento também oferece importantes contribuições práticas. Com o entendimento de que a emocionalidade de líderes, sobretudo, a negativa, possui efeito na identificação e na eficácia, tanto de seguidores quanto de líderes, o presente trabalho propõe, primeiramente, a atenção deste fato pelas organizações. Em segundo, oferece insights elucidativos sobre a importância de se tratar líderes que expressem emoções negativas no ambiente laboral, como forma de alterar toda a dinâmica ali presente. Nesse sentido, este desenvolvimento emocional/afetivo do líder poderia, possivelmente, ser induzido por meio de culturas organizacionais e ocupacionais mais voltadas para pessoas. Assim, seria necessário também, no mínimo, entender as expectativas dos líderes que fazem parte da corporação, como forma de os compreender para melhor facilitar esta mudança emocional/afetiva e, caso necessário, evidenciar seu desalinhamento com os valores organizacionais.

Uma limitação do experimento 2 é que ele obteve, assim como o primeiro, uma baixa taxa de resposta, sendo menor do que a que era esperada. Buscando contrabalançar esta limitação, novas sessões foram realizadas até que se neutralizasse totalmente este efeito negativo e conseguisse o número total desejado de participantes (pelo menos 50 em cada condição), conforme anteriormente planejado.

Para futuros estudos são sugeridas mais pesquisas investigando o papel das emoções na liderança autêntica. Caberia, inclusive, observar ainda possíveis efeitos do uso de emoções positivas e negativas do seguidor e suas influências na escolha por um determinado tipo de líder. Talvez um seguidor com emoções positivas tenha a tendência de valorizar mais o líder autêntico, por se identificar 
mais com indivíduos que compartilham das mesmas emoções. Vale, também, realizar pesquisas semelhantes a esta em outros contextos, como forma de reavaliar seus efeitos e generalizar resultados. Por fim, seria interessante, ainda, relacionar a emocionalidade do líder com outros construtos, como forma de buscar novas interações que possam fornecer uma visão mais holística de todo o processo. 


\section{5 \\ Discussões Gerais e Considerações Finais}

O objetivo central do presente estudo foi testar, por meio de dois experimentos, a percepção de efetividade do líder, visualizada sob duas vertentes: grau de identificação e atribuição de eficácia de diferentes tipos de seguidores com uma liderança autêntica. Assim, o trabalho como um todo oferece importantes contribuições teóricas para a literatura. Primeiro, é atendida a necessidade exposta por Northouse (2010) de se realizar mais estudos empíricos sobre a liderança autêntica e seus efeitos. Além disso, o estudo representa uma resposta aos anseios de Avolio e Reichard (2008), Gardner et al. (2011) e Shamir (2007), por investigar melhor os potenciais efeitos de seguidores no fenômeno da liderança. Nesse sentido, ainda contribui trazendo a perspectiva da cultura ocupacional para as discussões de liderança, até então pouco vista na literatura e, também, expande o conhecimento do papel das emoções na valoração de um líder com alto grau de autenticidade, conforme relevância exposta nos pilares de desenvolvimento da teoria (AVOLIO et al., 2004).

Por outro lado, o presente trabalho apresenta algumas limitações, que devem ser notadas. De início, as métricas utilizadas tanto para o grau de identificação quanto para mensuração da percepção de eficácia são compostas de apenas três itens cada, o que, muitas vezes, dificulta a captação total das avaliações sobre o construto e pode diferir conceitualmente de uma medida mais geral dessas variáveis. Por outro lado, como forma de mitigar esta limitação, as métricas foram pré-testadas e validadas por meio da obtenção de Alphas de Cronbach superiores a 0.80. Nesse sentido, seria interessante, a utilização, em futuros estudos, de outras métricas para mensuração da identificação e eficácia do líder. Outra limitação, em ambos os experimentos, foi a taxa de resposta ter sido bem abaixo da esperada, o que impossibilitou, por exemplo, de no primeiro estudo comparar profissionais de finanças e marketing com áreas mais específicas, como o caso, talvez, de recursos humanos. Contudo, para minimizar esse problema, buscou-se um número maior de sessões e de participantes do que havia sido planejado, apesar de ainda não ter sido plenamente suficiente. Assim, é pretendido, posteriormente, dar continuidade a essa pesquisa por meio da ampliação da coleta de dados, expandindo assim os 
resultados por intermédio de uma comparação mais fidedigna entre culturas ocupacionais.

O estudo, entretanto, possui fortes contribuições, por fornecer subsídios a uma maior discussão dos pressupostos básicos que regem a teoria da liderança autêntica, assim como seu alcance prático no contexto atual. Em resumo, a pesquisa demonstra, por meio da utilização de um método pouco empregado (DAY; ANTONAKIS, 2012), o envolvimento entre diversos elementos na liderança, explicando potenciais efeitos e levantando novos caminhos, frutos dos achados empíricos. Dessa forma, há a esperança de que este trabalho motive pesquisadores na contínua análise da interseção entre discursos, emoções e autenticidade na liderança. 


\section{6 \\ Referências bibliográficas}

ALLPORT, G.W.; ROSS, J.M. Personal religious orientation and prejudice. Journal of Personality and Social Psychology, v. 5, n. 4, pp. 432-443, 1967.

ASHKANASY, N. M.; TSE, B. Transformational leadership as management of emotions: A conceptual review. In: ASHKANASY, N. M.; HARTEL, C. E. (Eds), Emotions in the workplace: Research, theory, and practice (pp. 221-235). Westport, CT: Quorum Books/Greenwald Publishing Group, 2000.

AVOLIO, B. J.; GARDNER, W. L. Authentic leadership development: getting to the root of positive forms of leadership. The Leadership Quarterly, v. 16, n. 3, pp. 315-338, 2005.

AVOLIO, B. J.; GARDNER, W. L.; WALUMBWA, F. O.; LUTHANS, F.; MAY, D. R. Unlocking the mask: a look at the process by which authentic leaders impact follower attitudes and behaviors. The Leadership Quarterly, v. 15, n. 6, pp. 801-823, 2004.

AVOLIO, B. J.; REICHARD, R. J. The rise of authentic followership. In: RIGGIO, R. E.; CHALEFF, I.; LIPMAN-BLUMEN, J. (Eds.), The art of followership: How great followers create great leaders and organizations (pp. 325-337). San Francisco, CA: Jossey-Bass, 2008.

AVOLIO, B. J; WALUMBWA, F. O.; WEBER, T. J. Leadership: Current theories, research, and future directions. Annual Review of Psychology, v. 60, pp. 421-449, 2009.

AWAMLEH, R.; GARDNER, W. L. Perceptions of leader charisma and effectiveness: The effects of vision content, delivery, and organizational performance. The Leadership Quarterly, v. 10, n. 3, pp. 345-373, 1999.

BADARACCO, JR., J. L.; WEBB, A. P. 'Business Ethics: A View From the Trenches', California Management Review, v. 37, n. 2, p. 8-28, 1995.

BANDURA, A. Social learning theory. Englewood Cliffs, NJ: Prentice Hall, 1977.

BANDURA, A. Social foundations of thought and action: A social cognitive theory. Englewood Cliffs, NJ: Prentice- Hall, Inc. 1986.

BASS, B. M. Bass and Stogdill's handbook of leadership. New York: Free Press, 1990. 
BASS, B. M. Transformational leadership: Industry, military, and educational impact. Mahwah, NJ7 Lawrence Erlbaum, 1998.

BASS, B. M.; STEIDLMEIER, P. Ethics, character, and authentic transformational leadership behavior. The Leadership Quarterly, v. 10, n. 2, pp. 181-217, 1999.

BASS, B. M. The Bass handbook of leadership: Theory, research, and managerial applications. (4th ed.). New York: Free Press, 2008.

BAUMHART, R. C. 'How Ethical are Businessmen?', Harvard Business Review, v. 39, p. 156-157, 1961.

BEGLEY, P. T. In pursuit of authentic school leadership practices. International Journal of Leadership in Education, v. 4, n. 4, pp. 353-365, 2001.

BENNIS, W. Leadership theory and administrative behavior. Administrative Science Quarterly, v. 4, pp. 259-301, 1959.

BERGAMINI, C. W. Liderança: administração de sentido. São Paulo: Atlas, 2009.

BERSON, Y.; AVOLIO, B. J. Transformational leadership and the dissemination of organizational goals: A case study of a telecommunication firm. The Leadership Quarterly, v. 15, n. 5, pp. 625-646, 2004.

BOATRIGHT, J. R. Ethics in Finance. Blackwell, Malden, USA, 1999.

BONO, J. E.; ILIES, R. Charisma, positive emotions and mood contagion. The Leadership Quarterly, v. 17, n. 4, pp. 317-334, 2006.

BOWDITCH, J. L.; BUONO, A. F. Elementos do comportamento organizacional. São Paulo: Pioneira, 2002.

BRIEF, A. P.; WEISS, H. M. Organizational behavior: Affect in the workplace. Annual Review of Psychology, v. 53, n. 1, pp. 279-307, 2002.

BROWN, D. J. In the minds of followers: Follower-centric approaches to leadership. In: DAY D. V.; ANTONAKIS J. (Eds.) The nature of leadership (2 ed., pp. 331-362). Los Angeles: SAGE, 2012.

BRYMAN, A. Liderança nas organizações. In: CLEGG, S. R.; HARDY, C.; NORD, W. R. (Org.). Handbook de estudos organizacionais (pp. 257-281). Volume 3, São Paulo: Atlas, 2004.

BURNS, J. M. Leadership. New York7 Harper \& Row Publishers, 1978. 
CARSTEN, M. K.; UHL-BIEN, M.; WEST, B. J.; PATERA, J. L.; MCGREGOR, R. Exploring social constructions of followership: A qualitative study. The Leadership Quarterly, v. 21, n. 3, pp. 543-562, 2010.

CASSELL, E. J. Compassion. In: SNYDER C. R.; LOPEZ S. J. (Eds.), Handbook of positive psychology (pp. 434 - 445). New York7 Oxford University Press, 2002.

CAVAZOTTE, F. S. C. N.; DUARTE, C.; GOBBO, A. Líder autêntico, trabalho seguro: A influência da liderança sobre o desempenho em segurança. Brazilian Business Review, v. 10, n. 2, pp. 97-123, 2013.

CHALEFF, I. The courageous follower: Standing up to and for leaders. San Francisco: Berrett-Koehler, 1995.

CHERULNIK, P. D.; DONLEY, K. A.; WIEWEL, T. R.; MILLER, S. Charisma is contagious: The effect of leaders' charisma on observers' affect. Journal of Applied Social Psychology, v. 31, n. 10, pp. 2149-2159, 2001.

CHONKO, L. B.; HUNT, S. D. 'Ethics and Marketing Management: An Empirical Examination', Journal of Business Research, v. 13, p. 339-359, 1985. CIANCI, A.; HANNAH, S.; ROBERTS, R.; TSAKUMIS, G. T. The effects of authentic leadership on followers' ethical decision-making in the face of temptation: An experimental study. The Leadership Quarterly, v. 25, n. 3, pp 581-594, 2014

CIULLA, J.B. Leadership ethics: mapping the territory. Business Ethics Quarterly, v. 5, n. 1, pp. 5-28, 1995.

CIULLA, J. B. The Ethics of Leadership. Belmont, CA: Wadsworth/Thomson Learning, 2003

CONGER, J. A.; KANUNGO, R. N. Toward a behavioral theory of charismatic leadership in organizational settings. Academy of Management Review, v. 12, n. 4, pp. 637-647, 1987.

CONGER J. A.; KANUNGO R. N. Charismatic leadership in organizations: Perceived behavioral attributes and their measurement. Journal of Organizational Behavior, v. 15, n. 5, pp. 439-452, 1994.

CONNELY, S.; RUARK, G. Leadership style and activating potential as moderators of the relationship between leader emotional valence and outcomes. The Leadership Quarterly, v. 21, n. 5, pp. 745-764, 2010. 
COOPER, C. D.; SCANDURA, T. A.; SCHRIESHEIM, C. A. Looking forward but learning from our past: Potential challenges to developing authentic leadership theory and authentic leaders. The Leadership Quarterly, v. 16, n. 3, pp. 475493, 2005.

DASBOROUGH, M. T.; ASHKANASY, N. M. Emotion and attribution of intentionality in leader-member relationships. The Leadership Quarterly, v. 13, n. 5, pp. $615-634,2002$.

DAVIS, M. H. Empathy: A social psychological approach. Madison, WI: Brown and Benchmark, 1994.

DAY, D. V.; ANTONAKIS, J. The nature of Leadership. 2a Ed. SAGE Publications, Inc. 2012.

DECELleS, K. A.; MARGOLIS, J. D.; DERUE, D. S.; CERANIC, T. L. Does Power corrupt or enable? When and why Power facilitates self-interested behavior. Journal of Applied Psychology, v. 97, n. 3, pp. 681-689, 2012.

DELFINO, I. A. L.; SILVA, A. B.; ROHDE, L. R. A produção acadêmica sobre liderança no Brasil: Uma análise bibliométrica dos artigos publicados em eventos e periódicos entre 1995 e 2009. Anais do XXXIV Encontro da ANPAD, Rio de janeiro, RJ, Brasil, 2010.

DUNFEE, T. W., SMITH, N. C.; ROSS JR, W. T. 'Social Contracts and Marketing Ethics', Journal of Marketing, v. 63, p. 14-32, 1999.

EBOLI, C.; CAVAZOTTE, F. S. N.; LUCENA, J. O impacto da autenticidade do líder e do foco em resultados sobre o desempenho no trabalho: Um estudo com funcionários de um banco privado brasileiro. Anais do XXXVI Encontro da ANPAD, Rio de Janeiro, RJ, Brasil, 36, 2012.

EKMAN, P. Should we call it expression or communication? Innovations in Social Science Research, v. 10, n. 4, p. 333-344, 1997.

FERREL O.C.; FRAEDRICH, J.; FERREL, L. Ética Empresarial: dilemas, tomadas de decisões e casos. (4a . Ed.) Rio de Janeiro: Reichmann \& Affonso Ed., 2000.

FIEDLER, F. E. A theory of leadership effectiveness. New York: McGraw-Hill, 1967.

FISHER, C. D. Antecedents and consequences of real-time affective reactions at work. Motivation and Emotion, v. 26, n. 1, p. 3-30, 2002. 
FRIJDA, N. H. Moods, emotion episodes and emotions. In: LEWIS, M.; HAVILAND, J. M. (Eds.), Handbook of Emotions (p. 381-403). New York: Guilford Press, 1993.

FRIJDA, N. H. The psychologists' point of view. In: LEWIS, M.; HAVILANDJONES, J. M. (Eds.), Handbook of emotions (p. 59-74). (2nd ed.). New York: Guilford Press, 2000.

FRIJDA, N. H.; MANSTEAD, A. S. R.; BEM, S. Emotions and beliefs: How feelings influence thoughts. Cambridge, UK7 University Press, 2000.

GADDIS, B.; CONNELLY, S.; MUMFORD, M. D. Failure feedback as an affective event: Influences of leader affect on subordinate attitudes and performance. The Leadership Quarterly, v. 15, n. 5, p. 663-686, 2004.

GARDNER, W. L.; AVOLIO, B. J.; LUTHANS, F.; MAY, D. R.; WALUMBWA, F. O. "Can you see the real me?" A self-based model of authentic leader and follower development. The Leadership Quarterly, v. 16, n. 3, p. 343$372,2005$.

GARDNER, W. L.; COGLISER, C. C.; DAVIS, K. M.; DICKENS, M. P. Authentic leadership: A review of the literature and research agenda. The Leadership Quarterly, v. 22, n. 6, p. 1120-1145, 2011.

GARDNER, W. L; LOWE, K. B.; MOSS, T. W.; MAHONEY, K. T.; COGLISER, C. C. Scholarly leadership of the study of leadership: A review of The Leadership Quarterly's second decade, 2000-2009. The Leadership Quarterly, v. 21, n. 6, pp. 922-958, 2010.

GEORGE, J. M. Group affective tone. In: WEST, M. (Ed.), Handbook of work group psychology (pp. 77-93). Sussex, England: Wiley, 1996.

GEORGE, W. Authentic leadership: Rediscovering the secrets to creating lasting value. San Francisco: Jossey-Bass, 2003.

GERSTNER, C. R.; DAY, D. V. Meta-analytic review of leader-member exchange theory: correlates and construct issues. Journal of Applied Psychology, v. 82, n. 6, pp. 827-844, 1997.

GOHM, C. L.; CLORE, G. L. Four latent traits of emotional experience and their involvement in well-being, coping, and attributional style. Cognition and Emotion, v. 16, n. 4, pp. 495-518, 2002.

GOLDBERG, L. R.; JOHNSON, J. A.; EBER, H. W.; HOGAN, R.; ASHTON, M. C.; CLONINGER, C. R.; GOUGH, H. G. The International Personality Item 
Pool and the future of public-domain personality measures. Journal of Research in Personality, v. 40, n. 1, pp. 84-96, 2006.

GOOTY, J.; CONNELLY, S.; GRIFFITH, J.; GUPTA, A. Leadership, affect and emotions: A state of the science review. The Leadership Quarterly, v. 21, n. 6, pp. 979-1004, 2010.

GRAEN, G. B.; UHL-BIEN, M. Relationship-based approach to leadership: Development of leader-member exchange (LMX) theory over 25 years: Apllying a multi-level multi-domain perspective. The Leadership Quarterly, v. 6, n. 2, pp. 219-247, 1995.

GROSSMAN, R. J. Emotions at work. Health Forum Journal, v. 43, n. 5, pp. $18-22,2000$.

HARTER, S. Authenticity. In: SNYDER, C. S.; LOPEZ, S. J. (Eds.), Handbook of positive psychology (pp. 382-394). Oxford: Oxford University Press, 2002.

HOGG, M. A.; HAINS, S. C.; MASON, I. Identification and leadership in small groups: Salience, frame of reference, and leader stereotypicality effects on leader evaluations. Journal of Personality and Social Psychology, v. 75, n. 5, p. 1248$1263,1998$.

HOUSE, R. J. A 1976 theory of charismatic leadership. In: HOUSE, R. J.; HUNT, J. G.; LARSON, L. L. (Eds.), Leadership: The cutting edge (pp. 189-207). Carbondale: Southern Illinois University Press, 1977.

HOWELL, J. M.; SHAMIR, B. The role of followers in the charismatic leadership process: Relationships and their consequences. Academy of Management Review, v. 30, n. 1, p. 96 - 112, 2005.

HUGHES, R.; GINNETT, R.; CURPHY, G. Leadership: Enhancing the lessons of experience. (5th ed.). New York: McGraw-Hill/Irwin, 2005

HUMPHREY, R. H. (Ed.). Affect and emotion: New directions in management, theory and research. USA: Information Age Publishing, 2008.

IZARD, C. E. The Psychology of Emotions. New York: Plenum, 1991.

ILIES, R.; FULMER, I. S.; SPITZMULLER, M.; JOHNSON, M. D. Personality and citizenship behavior: The mediating role of job satisfaction. Journal of Applied Psychology, v. 94, n. 4, p. 945-959, 2009.

ILIES, R.; MORGESON, F. P.; NAHRGANG, J. D. Authentic leadership and eudaemonic well-being: Understanding leader-follower outcomes. The Leadership Quarterly, v. 16, n. 3, p. 373-394, 2005. 
JOHNSON, G.; SCHOLES, K. Exploring Corporate Strategy: Text and Cases, (6th Edition). Pearson Education, Harlow, Essex, UK, 2002.

KELLEY, R. E. In praise of followers. Harvard Business Review, pp. 142-148, 1988.

KELLY, J. R.; BARSADE, S. Mood and Emotions in Small Groups and Work Teams. Organizational Behavior and Human Decision Processes, v. 86, n. 1, pp. 99-130, 2001.

KOTTER, J. P. What leaders really do. Harvard Business Review, v. 79, n. 11, p. 85-96, 2001.

LEWIS, K. M. When leaders display emotion: How followers respond to negative emotional expression of male and female leaders. Journal of Organizational Behavior, v. 21, n. 2, $221-234,2000$.

LORD, R. G.; BROWN, D. J. Leadership Processes and follower identity. Mahwah, NJ: Lawrence Erlbaum Associates, 2004.

LORD, R. G.; MAHER, K. J. Leadership and information processing: Linking perceptions and performance. Cambridge: Unwin Hyman Ltd., 1991.

LUTHANS, F.; AVOLIO, B. J. Authentic leadership development. In: CAMERON, K. S.; DUTTON, J. E.; QUINN, R. E. (Eds.), Positive organizational scholarship (pp. 241-258). San Francisco: Berrett-Koehler, 2003. MADERA, J.; SMITH, D. B. The effects of leader negative emotions on evaluations of leadership in a crisis situation: the role of anger and sadness. The Leadership Quarterly, v. 20, n. 2, pp. 103-114, 2009.

MCCOLL-KENNEDY, J.; ANDERSON, R. Impact of leadership style and emotions on subordinate performance. The Leadership Quarterly, v. 13, n. 5, pp. 545-559, 2002.

MCPHAIL, K. 'The Other Objective of Ethics Education: Re-humanizing the Accounting Profession -- A Study of Ethics Education in Law, Engineering, Medicine and Accountancy', Journal of Business Ethics, v. 34, p. 279-298, 2001.

MEINDL, J. R.; EHRLICH, S. B.; DUKERICH, J. M. The romance of leadership. Administrative Science Quarterly, v. 30, n. 1, p. 78-102, 1985.

MICHIE, S.; GOOTY, J. Values, emotions, and authenticity: Will the real leader please stand up?. The Leadership Quarterly, v. 16, n. 3, p. 441 - 457, 2005. 
MILITELLO, F.; SCHWALBERG, M. 'Ethical Conduct: What Financial Executives Do To Lead', Financial Executive, v. 19, n. 1, p. 49-51, 2003.

MONTEPARE, J. M.; DOBISH, H. The contribution of emotion perceptions and their overgeneralizations to trait impressions. Journal of Nonverbal Behavior, v. 27, n. 4, pp. 237-254, 2003.

MURPHY, P. E.; LACZNIAK, G. R. 'Marketing Ethics: A Review with Implications for Managers, Educators and Researchers', Review of Marketing, p. $251-265,1981$.

NEWCOMBE, M. J.; ASHKANASY, N. M. The role of affect and effective congruence in perceptions of leaders: An experimental Study. The Leadership Quarterly, v. 13, n. 5, p. 601-614, 2002.

NORTHOUSE, P. G. Leadership Theory and Practice. SAGE Publications, 2010.

OAKLEY, J. Morality and the emotions. London7 Routledge, 1992.

O'HIGGINS, E.; KELLEHER, B. Comparative perspectives on the ethical orientations of human resources, marketing and finance functional managers. Journal of Business Ethics, v. 56, n. 3, p. 275-288, 2005.

ORTONY, A.; ClORE, G. L.; COLLINS, A. The cognitive structure of emotions. Cambridge, MA: Cambridge University Press, 1988.

PARRY, K. W.; BRYMAN, A. Leadership in organizations. In: CLEGG, S.; HARDY, C.; NORD, W. (eds.), Handbook of Organization Studies ( $2^{\text {nd }}$ ed.). London: Sage. pp. 447-468, 2006.

PONEMON, L. A. 'Ethical Judgments in Accounting: A CognitiveDevelopmental Perspective', Critical Perspectives on Accounting, v. 1, p. 191$215,1990$.

RAJAH, R.; SONG, Z.; ARVEY, R. D. Emotionality and leadership: Taking stock of the past decade of research. The Leadership Quarterly, v. 22, n. 6, pp. 1107-1119, 2011.

RICHINS, M. L.; DAWSON, S. A consumer values orientation scale for materialism and its measurement: Scale development and validation. Journal of Consumer Research, v. 19, pp. 303-316, 1992.

ROST, J. C. Leadership for the twenty-first century. Westport, CO: Praeger, 1991. 
SANTOS, N. C.; MACHADO, L. A.; FRANCISCHETTI, C. E.; PADOVEZE, C. L.; FERREIRA, L. O.; OSWALDO, Y. C. A relevância da liderança no Brasil: Um estudo bibliométrico sobre a produção acadêmica no período de 2007 a 2012. Anais do XXXVII Encontro da ANPAD, Rio de Janeiro, RJ, Brasil, 37, 2013. SCHEIN, E. Cultura organizacional e liderança. São Paulo, SP: Editora Atlas, 2007.

SCHREYER, E. (2010, agosto 03). Why leadership matters. Disponível em: http://www.forbes.com/2010/03/08/leader-business-visionary-forbes-womanleadership-job.html. Recuperado em 20, Outubro, 2014.

SCHULMAN, P. Applying learned optimism to increase sales productivity. Journal of Personal Selling and Sales Management, v. 19, n. 1, pp. 31 - 37, 1999.

SHAMIR, B. "Introduction: From passive recipients to active co-producers -The roles of followers in the leadership process". In: SHAMIR, B.; PILLAI, R.; BLIGH, M.; UHL-BIEN, M. Follower-centered perspectives on leadership: A tribute to J. R. Meindl. Stamford, CT: Information Age Publishing, 2007.

SHAMIR, B.; EILAM, G. "What's your story?": A life-stories approach to authentic leadership development. The Leadership Quarterly, v. 16, n. 3, p. 395$417,2005$.

SHAMIR, B.; HOUSE, R.J.; ARTHUR, M. B. The motivational effect of charismatic leadership: A self-concept based theory. Organization Science, v. 4, n. 4, pp. 577-594, 1993.

SINACEUR, M.; NEALE, M. A.; VAN KLEEF, G. A.; ADAM, H. Hot or cold: Is communicating anger or threats more effective in negotiation? Journal of Applied Psychology, v. 96, n. 5, 1018-1032, 2011.

STOHS, J.; BRANNICK, T. 'Irish Managers' Perceptions of Business Ethics', IBAR - Irish Business and Administrative Research, v. 17, pp. 83-93, 1996.

STRUTTON, D.; LUMPKIN, J. R. The relationship between optimism and coping styles of salespeople. Journal of Personal Selling and Sales Management, v. 13, n. 2, pp. $71-82,1993$.

SUTTON, R. I.; RAFAELI, A. Untangling the relationship between displayed emotions and organizational sales: The case of convenience stores. Academy of Management Journal, v. 31, n. 3, pp. 461-487, 1988. 
SY, T.; CÔTÉ, S.; SAAVEDRA, R. The contagious leader: Impact of the leader's mood on the mood of group members, group affective tone, and group process. Journal of Applied Psychology, v. 90, n. 2, pp. 295-305, 2005.

TSALIKIS, J.; FRITZCHE, D. J. 'Business Ethics: A Literature Review with a Focus on Marketing Ethics', Journal of Business Ethics, v. 8, n. 9, p. 695-743, 1989.

TURANO, L. M.; CAVAZOTTE, F. S. C. N. Estudos sobre liderança segundo o The Leadership Quarterly: Quo Vadis? Uma Análise Bibliométrica de 2008 a 2013. Anais do XXXVIII Encontro da ANPAD, Rio de Janeiro, RJ, Brasil, 38, 2014.

VAN SETERS, D. A.; FIELD, R. H. G. The evolution of leadership theory. Journal of Organizational Management, v. 3, n. 3, pp. 29-45, 1990.

VEIT T. E.; MURPHY, M. R. 'Ethics Violations: A Survey of Investment Analysts', Journal of Business Ethics, v. 15, p. 1287-1297, 1996.

VILAS-BOAS, O. T., CAVAZOTTE, F. S. C. N. Authentic leadership: Effects on work performance and analysis of mediating processes. Anais do XXXV Encontro da ANPAD, Rio de Janeiro, RJ, Brasil, 35, 2011.

WALUMBWA, F. O.; AVOLIO, B. J.; GARDNER, W. L.; WERNSING, T. S., PETERSON, S. J. Authentic leadership: Development and validation of a theorybased measure. Journal of Management, v. 34, n. 1, pp. 89-126, 2008.

WALUMBWA, F. O.; WANG, P.; WANG, H.; SCHAUBROECK, J.; AVOLIO, B. J. Psychological processes linking authentic leadership to follower behaviors. The Leadership Quarterly, v. 21, n. 5, pp. 901-914, 2010.

WEISS, H. M.; CROPANZANO, R. Affective events theory: a theoretical discussion of the structure, causes and consequences of affective experiences at work. In: SUTTON, R. I.; STAW, B. M. (Eds.), Research in organizational behavior, volume 18 (pp. 1 - 74). Greenwich, CT: JAI Press, 1996.

WEISS, J. W. Business Ethics, (3rd Edition). Thomson, Mason, OH, 2003.

WEISS, W. H. 'The Need for Ethical Behavior', Supervision, v. 58, p. 15-18, 1997.

WILEY, C. 'Reexamining Perceived Ethics Issues and Ethics Roles Among Employment Managers', Journal of Business Ethics, v. 17, p. 147-161, 1998.

YUKL, G. Managerial leadership: A review of theory and research. Journal of Management, v. 15, n. 2, p. 251-289, 1989. 
YUKL, G. Leadership in organizations. Upper Saddle River, NJ7 Prentice-Hall, 2006.

YUKL, G. Effective leadership behavior: What we know and what questions need more attention. Academy of Management Perspectives, v. 26, n. 4, pp. 66-85, 2012. 


\section{APÊNDICE 1 - Discursos dos vídeos}

\section{$\underline{\text { Discurso Neutro }}$}

Prezados Colaboradores, bom dia. Sou Roberto Pereira, Diretor Executivo do Grupo Miller e gostaria de passar algumas informações para vocês sobre a nossa empresa. O grupo Miller atua no Brasil há sete anos. A empresa conta hoje com aproximadamente 4 mil funcionários, em três estados brasileiros: Rio de Janeiro, São Paulo e Minas Gerais. Desde o início das nossas operações temos tido bons resultados no Brasil. O primeiro trimestre de 2014 foi um bom começo para as nossas atividades nas três praças. Minas é a nossa operação mais nova, e em 2014 uma das nossas metas é solidificar essa posição. Nós mantivemos o nosso market share no ano passado e, até o final de 2015, pretendemos dar continuidade ao nosso plano estratégico de expansão dos negócios da Miller no território nacional. Seja bem-vindo ao Grupo Miller.

\section{$\underline{\text { Discurso do líder autêntico }}$}

Prezados Colaboradores, bom dia. Sou Roberto Pereira, Diretor Executivo do Grupo Miller e gostaria de passar algumas informações para vocês sobre a nossa empresa. O grupo Miller atua no Brasil há sete anos. A empresa conta hoje com aproximadamente 4 mil funcionários, em três estados brasileiros: Rio de Janeiro, São Paulo e Minas Gerais. Desde o início das nossas operações temos tido bons resultados no Brasil. O primeiro trimestre de 2014 foi um bom começo para as nossas atividades nas três praças. Minas é a nossa operação mais nova, e em 2014 uma das nossas metas é solidificar essa posição. Nós mantivemos o nosso market share no ano passado e, até o final de 2015, pretendemos dar continuidade ao nosso plano estratégico de expansão dos negócios da Miller no território nacional. Seja bem-vindo ao Grupo Miller.

Aqui na Miller, a ética é um pilar central da empresa. Nós buscamos fazer nosso negócio com princípios, independente das pressões externas. A franqueza, a sinceridade no nosso convívio diário e a transparência nas informações são traços valorizados na companhia. Nós procuramos também cultivar um ambiente democrático, ouvir e considerar todas as opiniões, mesmo que sejam diferentes 
das nossas. Nós queremos estar sempre abertos para receber feedbacks, e conscientes do impacto que temos nas pessoas e na sociedade. Seja bem-vindo ao Grupo Miller.

\section{$\underline{\text { Discurso Inautêntico }}$}

Prezados Colaboradores, bom dia. Sou Roberto Pereira, Diretor Executivo do Grupo Miller e gostaria de passar algumas informações para vocês sobre a nossa empresa. $\mathrm{O}$ grupo Miller atua no Brasil há sete anos. A empresa conta hoje com aproximadamente 4 mil funcionários, em três estados brasileiros: Rio de Janeiro, São Paulo e Minas Gerais. Desde o início das nossas operações temos tido bons resultados no Brasil. O primeiro trimestre de 2014 foi um bom começo para as nossas atividades nas três praças. Minas é a nossa operação mais nova, e em 2014 uma das nossas metas é solidificar essa posição. Nós mantivemos o nosso market share no ano passado e, até o final de 2015, pretendemos dar continuidade ao nosso plano estratégico de expansão dos negócios da Miller no território nacional. Seja bem-vindo ao Grupo Miller.

Aqui na Miller, os resultados estão acima de tudo, não importa como o jogo vai ser jogado. Esperamos que quem está no comando conduza suas equipes com autoridade e sem melindres. Todas as informações das áreas e da empresa são sigilosas. Nós compartilhamos com o público externo apenas o que é estritamente necessário, e o que favorece a imagem da companhia. Nós mantemos o foco nos nossos interesses, e não perdemos tempo com firulas e lero-lero. Queremos com a gente somente os melhores, que entram aqui para ganhar. Seja bem-vindo ao Grupo Miller. 
APÊNDICE 2 - Questionário do Experimento 1
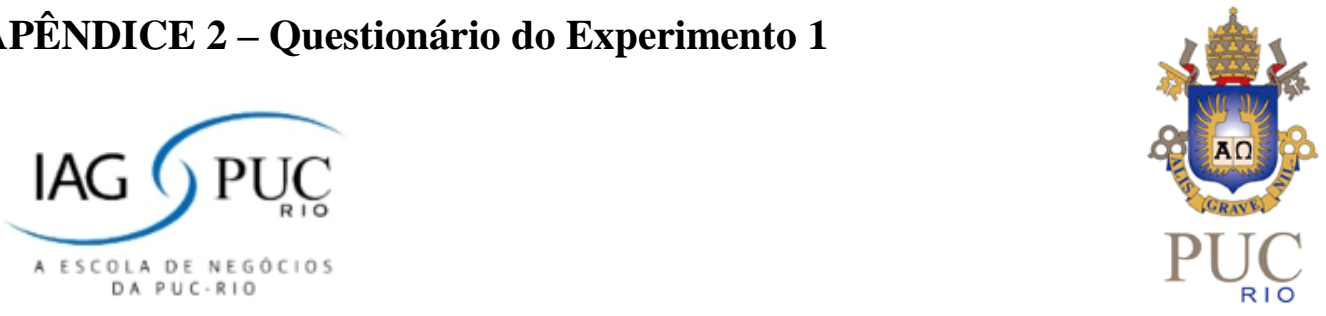

POR FAVOR, LEIA ATENTAMENTE ESTAS QUATRO INSTRUÇÕES ANTES DE INICIAR O PREENCHIMENTO DO QUESTIONÁRIO.

Prezado Participante,

1. Por Favor, só vire esta página após a apresentação do filme.

2. Pedimos, gentilmente, que não conversem com os colegas enquanto estiverem realizando a pesquisa. Aguarde o término de todos para compartilhar suas impressões.

3. Pedimos, também, que, por gentileza, não comentem esta pesquisa com colegas de outras turmas de MBA até o final da semana que vem, uma vez que pretendemos passar a mesma pesquisa em outras turmas.

4. Por favor, responda às questões da forma mais franca possível. Esta é uma pesquisa anônima. Assim, não é necessário se identificar neste questionário!

Desde já Agradeço pela Participação,

Lucas Martins Turano

Mestrando Acadêmico em Administração de Empresas, com ênfase em Organizações, no IAG/PUC-Rio. 
As questões a seguir se referem ao CEO do vídeo assistido. Leias as afirmações e preencha no quadro em branco ao lado de cada item, com base na escala abaixo, a opção que melhor descreva sua opinião:

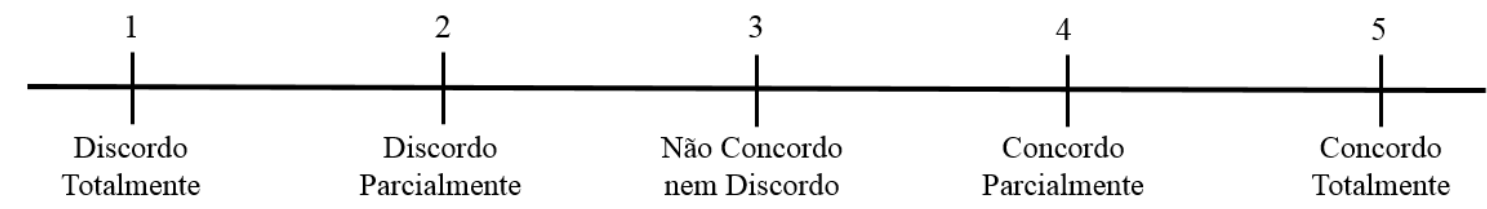

\begin{tabular}{|l|l|}
\hline & 1. Esse CEO corresponde à imagem que eu tenho de um líder. \\
\hline & 2. Esse CEO é um bom líder. \\
\hline & 3. Eu me identifico com esse CEO. \\
\hline 4. Eu gostaria de ter esse CEO como líder formal (chefe). \\
\hline 5. Eu me dedicaria mais e aumentaria minha produtividade com um líder como esse. \\
\hline & 6. Eu acredito que esse líder teria um alto desempenho na área em que trabalho. \\
\hline
\end{tabular}

Os itens a seguir contêm afirmativas referentes ao comportamento de líderes. Use a escala abaixo para avaliar até que ponto as declarações descrevem com precisão o CEO apresentado no vídeo.

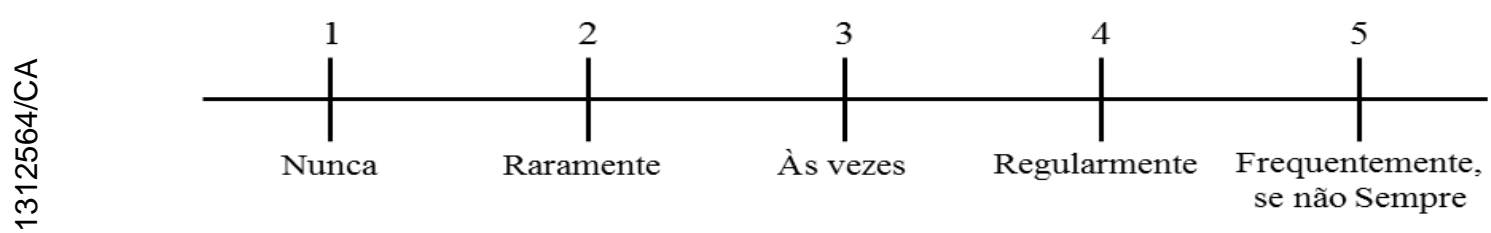

Para você, o líder do vídeo:

\begin{tabular}{|l|l|}
\hline & 1. Diz exatamente o que pensa. \\
\hline & 2. Admite quando comete erros. \\
\hline 3. Encoraja todos a dizer o que pensam. \\
\hline 4. Fala sempre a verdade. \\
\hline 5. Demonstra emoções que correspondem aos seus verdadeiros sentimentos. \\
\hline 6. Age de forma coerente com os princípios que defende. \\
\hline 7. Toma decisões com base nos seus valores centrais. \\
\hline 8. Pede aos seus subordinados que ajam de acordo com seus próprios valores centrais. \\
\hline 9. Toma decisões complexas com base em altos padrões de conduta ética. \\
\hline 10. Solicita visões e opiniões que divergem das suas. \\
\hline 11. Busca analisar todos os dados relevantes antes de se decidir. \\
\hline 12. Escuta cuidadosamente diferentes pontos de vista antes de chegar a uma conclusão. \\
\hline 13. Busca feedback para melhorar as suas interações com os demais. \\
\hline 14. Sabe com exatidão como os outros veem suas capacidades. \\
\hline 15. Sabe quando é o momento de reavaliar sua posição. \\
\hline 16. Mostra que compreende como cada uma das suas ações afeta aos outros. \\
\hline
\end{tabular}


As perguntas a seguir dizem respeito às suas características pessoais. Use a escala abaixo para indicar até que ponto as frases descrevem VOC $\hat{\mathbf{E}}$ de forma precisa.

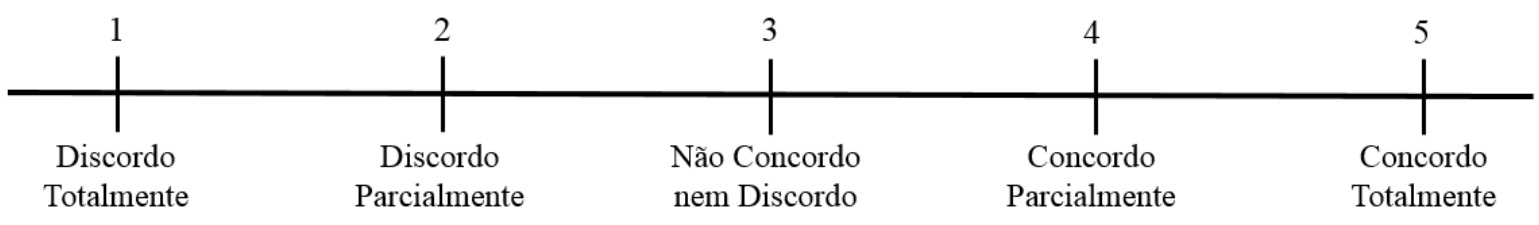

\begin{tabular}{|c|c|}
\hline & 1. Eu admiro pessoas que possuem casas, carros e roupas caras. \\
\hline & 2. Algumas das realizações mais importantes da vida incluem a aquisição de posses materiais. \\
\hline & 3. A quantidade de bens materiais que as pessoas possuem não é um sinal de sucesso para mim. \\
\hline & 4. As coisas que possuo dizem muito sobre o quão bem estou indo na vida. \\
\hline & 5. Eu gosto de possuir coisas que impressionam pessoas. \\
\hline & 6. Eu não presto muita atenção nos bens materiais que outras pessoas possuem. \\
\hline & 7. Eu geralmente compro somente as coisas que realmente necessito. \\
\hline & 8. Eu tento manter minha vida simples no referente a posses materiais. \\
\hline & 9. Os bens que possuo não são muito importantes para mim. \\
\hline 妾 & 10. Eu gosto de gastar dinheiro em coisas que não são úteis. \\
\hline$\stackrel{\text { }}{\stackrel{\text { m }}{m}}$ & 11. Comprar coisas me dá muito prazer. \\
\hline$\stackrel{0}{2}$ & 12. Eu gosto de muito luxo em minha vida. \\
\hline : & 13. Eu coloco menos ênfase nas coisas materiais do que a maioria das pessoas que conheço. \\
\hline I్ָరి & 14. Eu gosto de ler sobre a minha religião \\
\hline 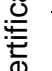 & 15. Ser uma boa pessoa é mais importante para mim do que as crenças religiosas que sigo. \\
\hline con & 16. É importante, para mim, passar um tempo sozinho refletindo e rezando. \\
\hline ه্র & 17. Eu, frequentemente, tenho a sensação da presença de Deus. \\
\hline$\vec{\alpha}$ & 18. Eu tento, fortemente, viver a minha vida de acordo com minhas crenças religiosas. \\
\hline & 19. A maneira como lido com a vida é baseada em minha religião. \\
\hline
\end{tabular}

A seguir, são apresentadas algumas situações do dia a dia no trabalho. Após sua leitura, indique, conforme a escala a seguir, como você avalia os comportamentos adotados.

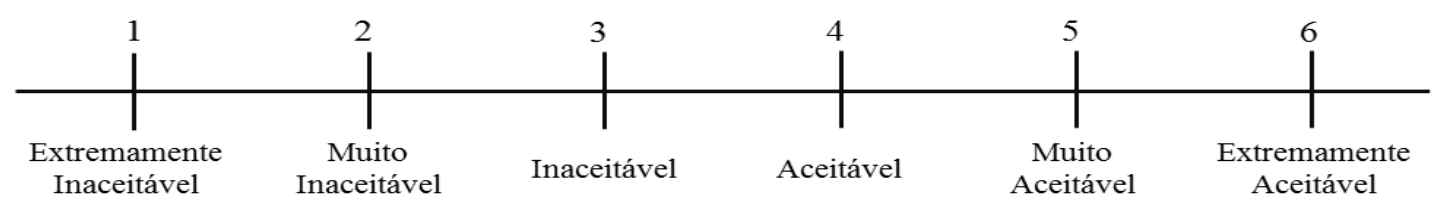

1. Um alto gerente da QWE é transferido para Bombai, onde a companhia tenta estabelecer um novo negócio. Com o intuito de competir no mercado indiano, o gerente sente que é necessário fazer pagamentos ao governo. Isso é contra as regras do país de origem, mas o gerente argumenta que é apenas um meio para entrar no mercado indiano e, na prática, não é ilegal no país. Ele continua a fazer pagamentos, sem obter permissão total da sede. 


\begin{tabular}{|c|}
\hline $\begin{array}{l}\text { 2. Luiza é uma contadora do departamento de finanças de uma grande empresa de impressão } \\
\text { e empacotamento. Seus gastos incluem a compra de gasolina para o carro da empresa que ela } \\
\text { possui. Ela também usa sua conta no posto de gasolina para encher o carro do marido, mas } \\
\text { apenas ocasionalmente. A empresa tem medo de perder Luiza para uma empresa concorrente } \\
\text { e ao invés de reclamar de seu uso indevido da conta, os gerentes fingem que não veem. }\end{array}$ \\
\hline $\begin{array}{l}\text { 3. Maria é contadora em sua empresa familiar. Nos últimos seis meses, o volume de negócios } \\
\text { e lucros reduziram consideravelmente, possivelmente devido à sazonalidade natural do } \\
\text { negócio. O pai de Maria está doente e requer atenções médicas caras. Por isso, a fim de pagar } \\
\text { essas contas ela realiza uns ajustes nas contas da empresa, declarando lucros mais baixos do } \\
\text { que os que a empresa, de fato, havia ganhado, para efeitos fiscais. }\end{array}$ \\
\hline $\begin{array}{l}\text { 4. SuperSave é uma grande cadeia de varejo do Reino Unido. Eles começaram recentemente a } \\
\text { compra de marcas de moda famosas, como Levi's e Calvin Klein, e agora vende-as a um } \\
\text { preço consideravelmente mais baixo do que em outras lojas. Essas marcas de moda estão } \\
\text { disponíveis a um preço mais baixo em países como os EUA e o Canadá. Os gerentes das lojas } \\
\text { de rua estão furiosos com essa tentativa de minar seus negócios. Os gestores da SuperSave } \\
\text { argumentam que se esses itens de moda podem ser comprados em outros países a este preço } \\
\text { mais baixo, então por que os seus clientes pagariam mais? Como você avalia o } \\
\text { comportamento das marcas de moda bem conhecidas, por permitir que seus produtos sejam } \\
\text { vendidos a dois preços diferentes? }\end{array}$ \\
\hline $\begin{array}{l}\text { 5. Um empregado da Phone Co. não está vendendo tantos celulares quanto seus superiores } \\
\text { gostariam. Foi dito a ele que se não atingir a sua quota, os superiores poderiam reconsiderar a } \\
\text { sua posição na empresa. No esforço para melhorar seus resultados, o empregado leva muitos } \\
\text { clientes a acreditar que, se comprar o produto da empresa, ele terá a opção de descontos em } \\
\text { novos modelos no futuro. A partir de então, as vendas aumentaram drasticamente e seus } \\
\text { supervisores ficaram muito satisfeitos com este aumento. Contudo, eles não têm } \\
\text { conhecimento das ofertas de desconto propostas pelo empregado. }\end{array}$ \\
\hline $\begin{array}{l}\text { 6. Um funcionário na TXL Co. é responsável pelo pagamento dos credores. Ultimamente, } \\
\text { alguns dos fornecedores têm se tornados cada vez mais impacientes com pagamentos em } \\
\text { atraso e se recusaram a permanecer com os negócios com a TXL Ltd. se isso continuasse. } \\
\text { Uma determinada empresa fornecedora está tendo dificuldades financeiras e estes } \\
\text { pagamentos atrasados estão causando vários problemas. O supervisor do empregado falou a } \\
\text { ele/ela para esperar receber um aviso final antes de pagar quaisquer credores, com propósitos } \\
\text { de fluxo de caixa. }\end{array}$ \\
\hline $\begin{array}{l}\text { 7. Green Ltd. Fornece materiais de escritório e construiu uma reputação de ser } \\
\text { ambientalmente amigável. Durante anos, eles forneceram somente papel reciclado e, muitas } \\
\text { vezes, são patrocinadores de programas em prol do meio ambiente. Porém, no último ano eles } \\
\text { têm fornecido papéis que não são reciclados, apesar de não terem divulgado isso aos seus } \\
\text { consumidores. }\end{array}$ \\
\hline
\end{tabular}


Use a escala abaixo para indicar até que ponto as frases descrevem VOC $\hat{\mathbf{E}}$ de forma precisa. Pense em como você é de maneira geral, e não como gostaria de ser no futuro. Descreva como você se vê em comparação com outras pessoas do mesmo sexo e idade, de forma honesta.

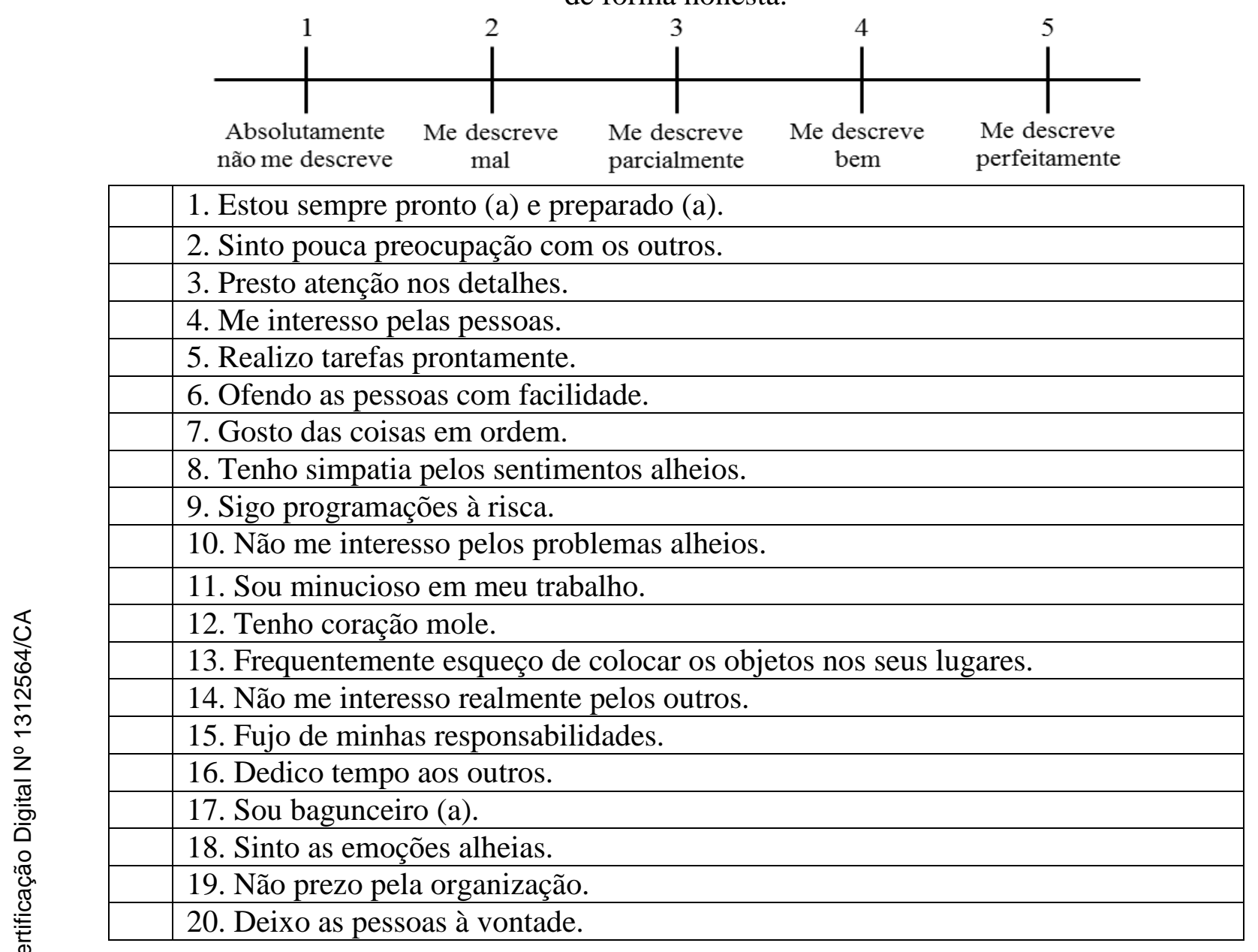

\section{Questões Demográficas}

1) Sexo: ( ) Feminino ( ) Masculino

2) Idade:

3) Formação (Curso de Graduação Realizado):

4) Empresa onde trabalha:

5) Área em que trabalha: ( ) Recursos Humanos ( ) Marketing/Vendas ( ) Finanças ( ) TI ( ) Logística ( ) Pesquisa \& Desenvolvimento ( ) Outra/Qual?:

6) Tempo que trabalha nesta empresa:

7) Tempo total de experiência na área: 
APÊNDICE 3 - Manipulação das emoções do líder

Líder Autêntico com Emoções Positivas

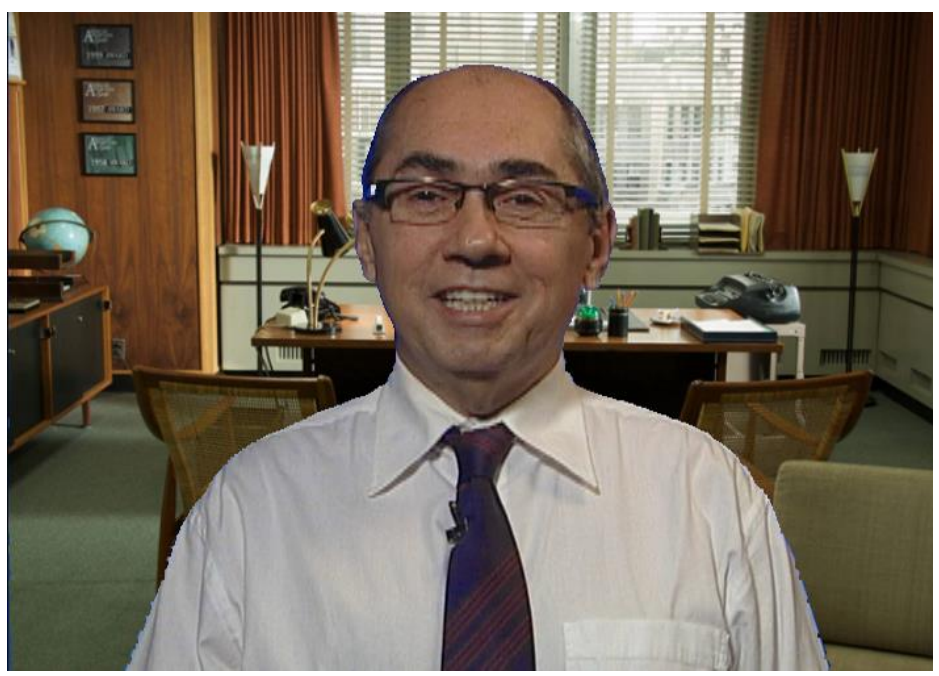

Líder Autêntico com Emoções Neutras

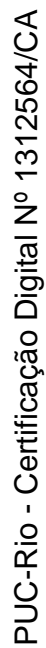

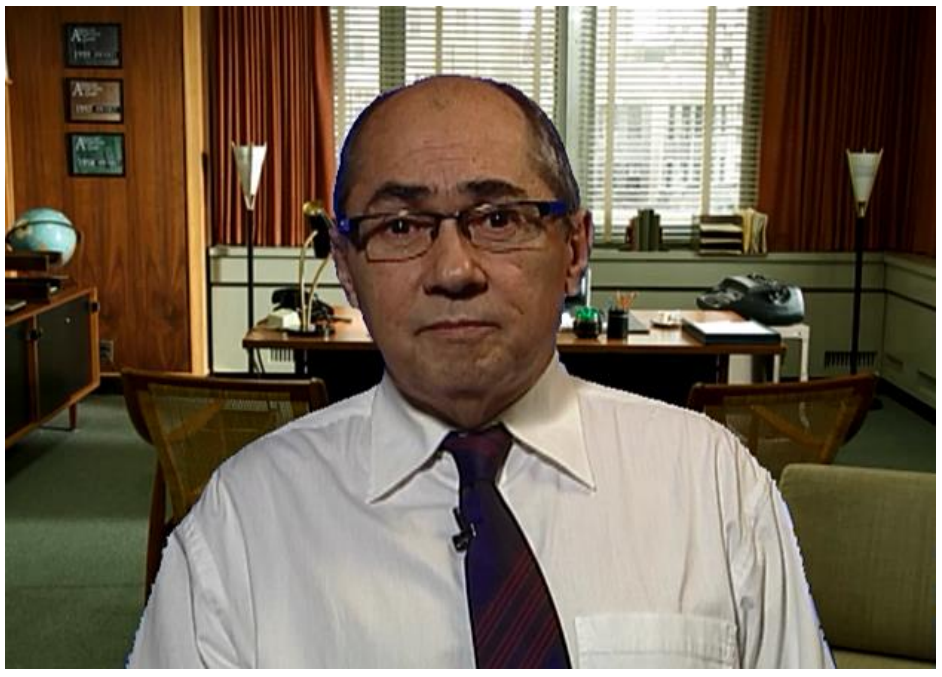

Líder Autêntico com Emoções Negativas

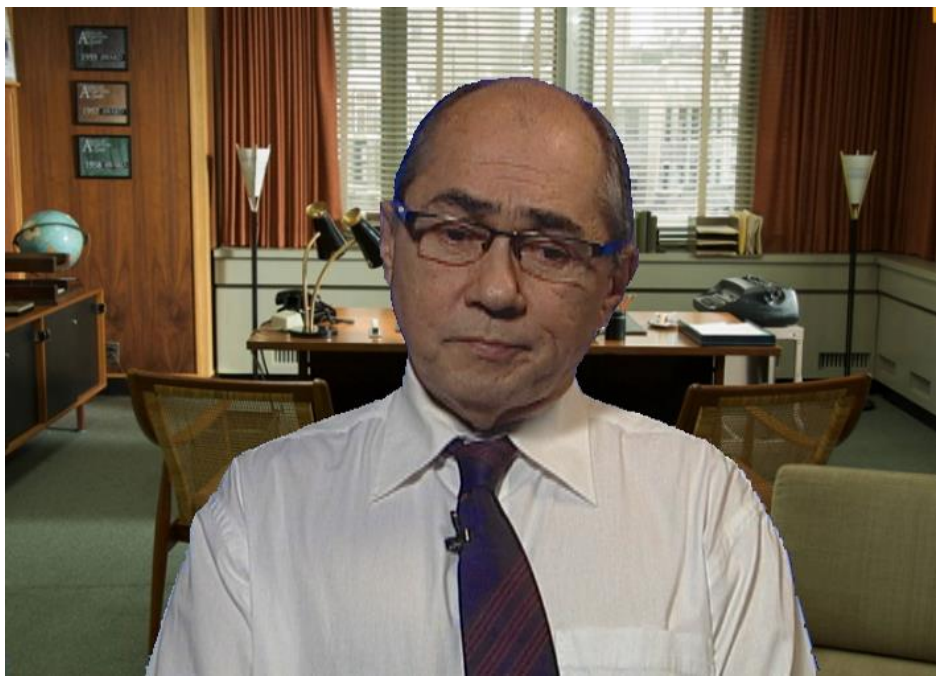


APÊNDICE 4 - Questionário do Experimento 2
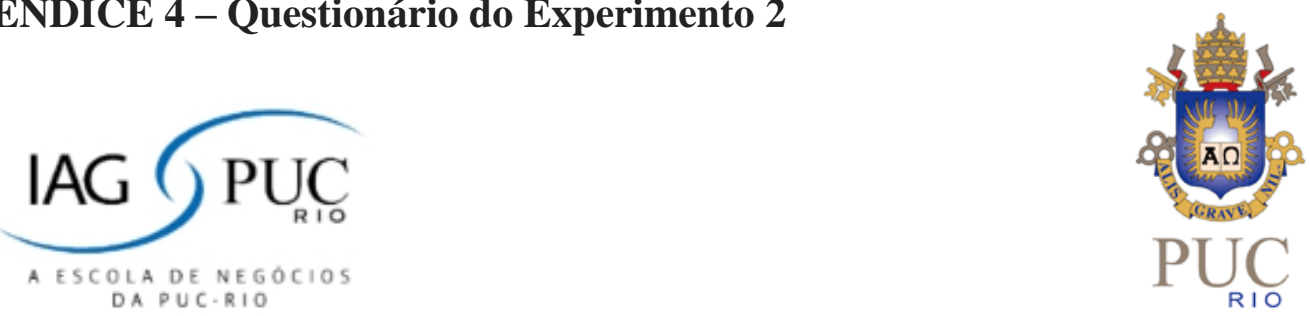

POR FAVOR, LEIA ATENTAMENTE ESTAS QUATRO INSTRUÇÕES ANTES DE INICIAR O PREENCHIMENTO DO QUESTIONÁRIO.

Prezado Participante,

5. Por Favor, só vire esta página após a apresentação do filme.

6. Pedimos, gentilmente, que não conversem com os colegas enquanto estiverem realizando a pesquisa. Aguarde o término de todos para compartilhar suas impressões.

7. Pedimos, também, que, por gentileza, não comentem esta pesquisa com colegas de outras turmas da graduação até o final da semana que vem, uma vez que pretendemos passar a mesma pesquisa em outras turmas.

8. Por favor, responda às questões da forma mais franca possível. Esta é uma pesquisa anônima. Assim, não é necessário se identificar neste questionário!

Desde já Agradeço pela Participação,

Lucas Martins Turano

Mestrando Acadêmico em Administração de Empresas, com ênfase em Organizações, no IAG/PUC-Rio. 
As questões a seguir se referem ao CEO do vídeo assistido. Leias as afirmações e preencha no quadro em branco ao lado de cada item, com base na escala abaixo, a opção que melhor descreva sua opinião:

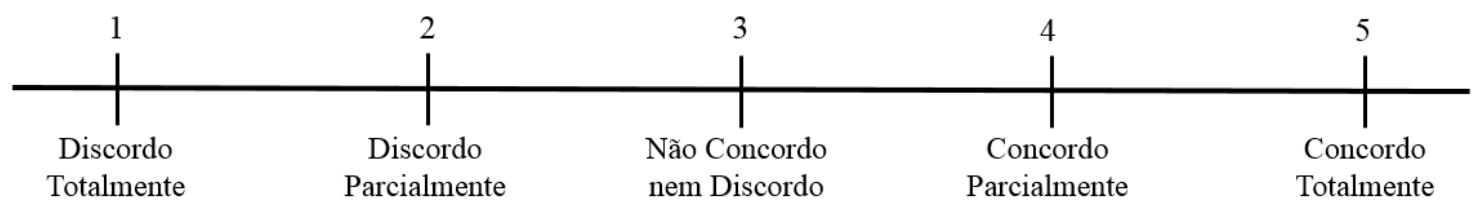

\begin{tabular}{|l|l|}
\hline & 1. Esse CEO corresponde à imagem que eu tenho de um líder. \\
\hline & 2. Esse CEO é um bom líder. \\
\hline 3. Eu me identifico com esse CEO. \\
\hline 4. Eu gostaria de ter esse CEO como líder formal (chefe). \\
\hline 5. Eu me dedicaria mais e aumentaria minha produtividade com um líder como esse. \\
\hline 6. Eu acredito que esse líder teria um alto desempenho na área em que trabalho. \\
\hline
\end{tabular}

Os itens a seguir contêm afirmativas referentes ao comportamento de líderes. Use a escala abaixo para avaliar até que ponto as declarações descrevem com precisão o CEO apresentado no vídeo.

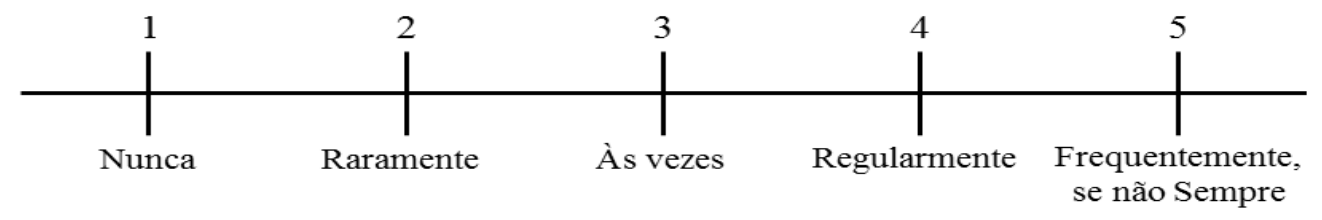

Para você, o líder do vídeo:

\begin{tabular}{|l|l|}
\hline & 1. Diz exatamente o que pensa. \\
\hline & 2. Admite quando comete erros. \\
\hline & 3. Encoraja todos a dizer o que pensam. \\
\hline & 4. Fala sempre a verdade. \\
\hline & 6. Demonstra emoções que correspondem aos seus verdadeiros sentimentos. \\
\hline & 7. Toma decisões com base nos seus valores centrais. \\
\hline 8. Pede aos seus subordinados que ajam de acordo com seus próprios valores centrais. \\
\hline 9. Toma decisões complexas com base em altos padrões de conduta ética. \\
\hline 10. Solicita visões e opiniões que divergem das suas. \\
\hline 11. Busca analisar todos os dados relevantes antes de se decidir. \\
\hline 12. Escuta cuidadosamente diferentes pontos de vista antes de chegar a uma conclusão. \\
\hline 13. Busca feedback para melhorar as suas interações com os demais. \\
\hline 14. Sabe com exatidão como os outros veem suas capacidades. \\
\hline 15. Sabe quando é o momento de reavaliar sua posição. \\
\hline 16. Mostra que compreende como cada uma das suas ações afeta aos outros. \\
\hline
\end{tabular}


As perguntas a seguir dizem respeito às características pessoais do CEO assistido no vídeo. Use a escala abaixo para indicar até que ponto as frases descrevem sua percepção sobre os sentimentos do líder.

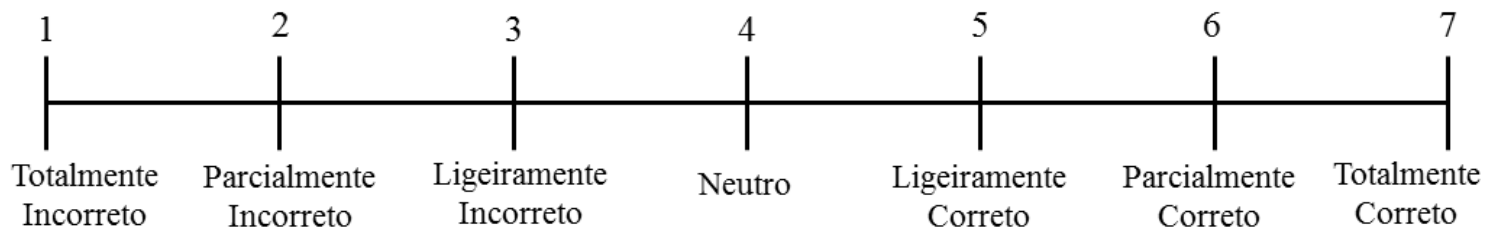

\begin{tabular}{|l|l|}
\hline & 1. Seguro. \\
\hline & 2. Apreensivo. \\
\hline & 3. Ansioso. \\
\hline & 4. Deprimido. \\
\hline & 5. Triste. \\
\hline & 6. Feliz. \\
\hline & 7. Calmo. \\
\hline & 8. Irritado. \\
\hline & 9. Furioso. \\
\hline & 10. Desanimado. \\
\hline & 11. Animado. \\
\hline & 12. Entusiasmado. \\
\hline 13. Energizado. \\
\hline 14. Cansado. \\
\hline & 15. Exausto. \\
\hline
\end{tabular}

As perguntas a seguir dizem respeito a você. Use a escala abaixo para indicar até que ponto as afirmações descrevem você de forma precisa.

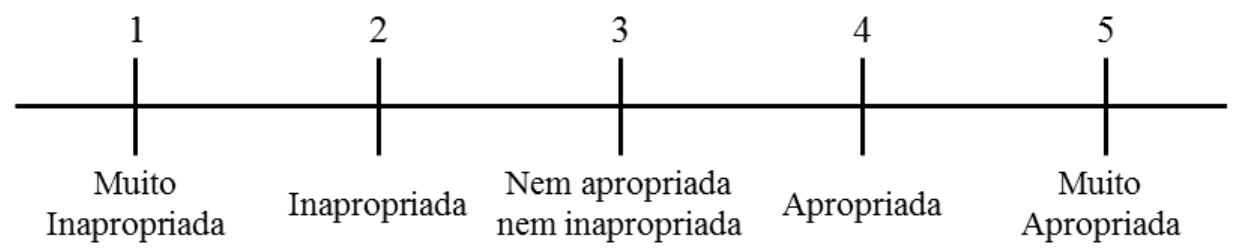

\begin{tabular}{|l|l|}
\hline & 1. Eu vivencio minhas emoções intensamente. \\
\hline & 2. Eu sinto a emoção de outras pessoas. \\
\hline & 3. Eu me sinto apaixonado por causas. \\
\hline & 4. Eu gosto de analisar a minha vida e a mim mesmo. \\
\hline & 5. Eu tento me compreender. \\
\hline 6. Eu raramente fico emocionado. \\
\hline 7. Eu não sou facilmente afetado por minhas emoções. \\
\hline 8. Eu raramente noto minhas reações emocionais. \\
\hline 9. Eu experencio muito poucos altos e baixos emocionais. \\
\hline 10. Eu não compreendo pessoas que ficam emocionadas. \\
\hline
\end{tabular}


Use a escala abaixo para indicar até que ponto as frases descrevem $\underline{\mathbf{V O C} \hat{\mathbf{E}}}$ de forma precisa.

Pense em como você é de maneira geral, e não como gostaria de ser no futuro. Descreva como você se vê em comparação com outras pessoas do mesmo sexo e idade, de forma honesta.

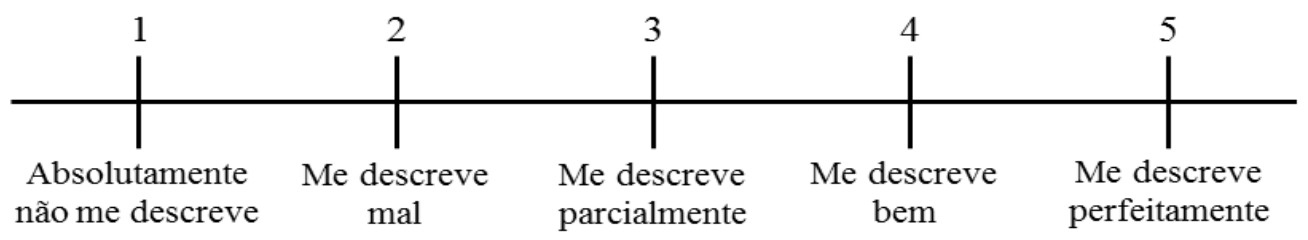

\begin{tabular}{|c|c|}
\hline & 1. Tenho vocabulário rico. \\
\hline & 2. Estou sempre pronto (a) e preparado (a). \\
\hline & 3. Me sinto relaxado(a) na maior parte do tempo. \\
\hline & 4. Estou sempre em evidência nas festas. \\
\hline & 5. Sinto pouca preocupação com os outros. \\
\hline & 6. Tenho imaginação fértil. \\
\hline 童 & 7. Presto atenção nos detalhes. \\
\hline & 8. Raramente me sinto bem. \\
\hline & 9. Não falo muito. \\
\hline & 10. Me interesso pelas pessoas. \\
\hline & 11. Tenho excelentes ideias. \\
\hline & 12. Realizo tarefas prontamente. \\
\hline & 13. Me perturbo facilmente. \\
\hline & 14. Sinto-me confortável com pessoas. \\
\hline & 15. Ofendo as pessoas com facilidade. \\
\hline & 16. Entendo coisas/instruções de maneira rápida. \\
\hline & 17. Gosto das coisas em ordem. \\
\hline & 18. Me preocupo com as coisas. \\
\hline & 19. Sou reservado. \\
\hline & 20. Tenho simpatia pelos sentimentos alheios. \\
\hline & 21. Uso palavras difíceis. \\
\hline & 22. Sigo programações à risca. \\
\hline & 23. Frequentemente me sinto bem. \\
\hline & 24. Início conversas \\
\hline
\end{tabular}




\begin{tabular}{|c|}
\hline 25. Não me interesso pelos problemas alheios. \\
\hline 26. Gasto tempo refletindo sobre as coisas. \\
\hline 27. Sou minucioso em meu trabalho. \\
\hline 28. Mudo de humor constantemente. \\
\hline 29. Falo pouco. \\
\hline 30. Tenho coração mole. \\
\hline 31. Sou cheio de ideais. \\
\hline 32. Frequentemente esqueço de colocar os objetos nos seus lugares. \\
\hline 33. Me aborreço facilmente. \\
\hline 34. Falo com um monte de gente diferente nas festas. \\
\hline 35. Não me interesso realmente pelos outros. \\
\hline 36. Tenho dificuldade para entender ideias abstratas. \\
\hline 37. Fujo de minhas responsabilidades. \\
\hline 38. Fico facilmente irritado. \\
\hline 39. Não gosto de chamar a atenção para mim. \\
\hline 40. Dedico tempo aos outros. \\
\hline 41. Não tenho interesse em ideias abstratas. \\
\hline 42. Sou bagunceiro (a). \\
\hline 43. Raramente fico deprimido. \\
\hline 44. Não me importo em ser o centro das atenções. \\
\hline 45. Sinto as emoções alheias. \\
\hline 46. Não tenho uma boa imaginação. \\
\hline 47. Não prezo pela organização. \\
\hline 48. Rapidamente mudo de um estado de humor para outro. \\
\hline 49. Fico mais quieto entre estranhos. \\
\hline
\end{tabular}


50. Deixo as pessoas à vontade.

\section{Questões Demográficas}

1) Sexo: ( ) Feminino ( ) Masculino

2) Idade:

3) Curso:

4) Período:

5) Turno: ( ) Manhã ( ) Tarde ( ) Noite

6) $\mathrm{CR}$ :

7) Nota no Enem:

8) Trabalha: ( ) Sim ( ) Não

9) Tempo de Experiência (Caso trabalhe):

Muito Obrigado por sua Participação! 